\title{
The chalicothere Metaschizotherium bavaricum (Perissodactyla, Chalicotheriidae, Schizotheriinae) from the Miocene (MN5) Lagerstätte of Sandelzhausen (Germany): description, comparison, and paleoecological significance
}

\author{
Margery C. Coombs
}

Received: 6 September 2006/Accepted: 16 March 2007/Published online: 13 February 2009

(c) Springer-Verlag 2009

\begin{abstract}
Within the fossil collection from the Sandelzhausen Lagerstätte in the Upper Freshwater Molasse near Mainburg, Germany, are remains of the schizotheriine chalicothere Metaschizotherium bavaricum, von Koenigswald, 1932. This new material includes elements from a large part of the body, and allows the dentition and postcranial skeleton of Metaschizotherium to be described in detail for the first time. At approximately $16 \mathrm{Ma}$ (MN5), $M$. bavaricum is now the best-known Early and Middle Miocene European schizotheriine and is important for comparative studies. It differs to some degree from earlier Miocene (MN2-MN4) European material attributed to Moropus sp. or Metaschizotherium wetzleri (Kowalewsky, 1873) and to a larger degree from the Late Miocene species Ancylotherium pentelicum (Gaudry and Lartet, 1856). At Sandelzhausen, M. bavaricum apparently lived in a moist forested environment, where it probably fed on leaves, fruit, and seeds. Members of the Chalicotheriinae, such as Anisodon and Chalicotherium, are not found at Sandelzhausen and may not have been present in Europe at this time. M. bavaricum, like other Schizotheriinae, did not have the bizarre gorilla-like proportions of the Chalicotheriinae. Instead, its general body proportions resemble those of contemporary schizotheriine chalicotheres on other continents, for example, Moropus from North America. M. bavaricum is slightly smaller than the type species of Metaschizotherium, M. fraasi von Koenigswald, 1932 (MN6-MN7) and differs from it in small ways that are still being explored as variation within and differences
\end{abstract}

M. C. Coombs $(\square)$

Department of Biology and Graduate Program in Organismic and Evolutionary Biology, University of Massachusetts, Amherst, MA 01003, USA

e-mail: mccc@bio.umass.edu between these species are clarified. The schizotheriine chalicothere from La Grive St.-Alban (France) referred to M. fraasi by von Koenigswald (Palaeontographica, Beitrage zur Naturgeschichte der Vorzeit 8:1-24, 1932) and Viret (Nouvelles Archives Musée d'Histoire Naturelle de Lyon 6:53-81, 1961) should be restudied and referred to a different taxon.

Keywords Metaschizotherium bavaricum . Sandelzhausen - Chalicothere - Schizotheriinae . Moropus · Ancylotherium · La Grive · Miocene

Kurzfassung Aus der Fossillagerstätte Sandelzhausen in der Oberen Süßwasser Molasse bei Mainburg (Deutschland) ist das schizotherine Krallentier Metaschizotherium bavaricum, von Koenigswald, 1932 belegt. Dieses neue Material erlaubt erstmals die detaillierte Beschreibung von Bezahnung und postcranialem Skelett von Metaschizotherium. Mit einem Alter von ca. 16 Mio Jahren (MN5) ist M. bavaricum derzeit das am besten belegte schizotherine Krallentier des Unter- und Mittelmiozäns Europas und von großer Bedeutung für vergleichende Studien. Es underscheidet sich nur in geringem Maße von Material aus dem Untermiozän (MN2MN4) Europas, das Moropus sp. oder Metaschizotherium wetzleri (Kowalewsky, 1873) zugeordnet wurde, differiert aber deutlich von der obermiozänen Art Ancylotherium pentelicum (Gaudry and Lartet, 1856). In Sandelzhausen lebte M. bavaricum offensichtlich in einem feuchten, bewaldeten Lebensraum und ernährte sich wahrscheinlich von Blättern, Früchten und Samen. Andere Vertreter von den Chalicotheriinae, wie z.B. Anisodon oder Chalicotherium, finden sich in Sandelzhausen nicht und waren wohl in dieser Zeit generell in Europa nicht beheimatet. Wie auch andere schizotherine Chalicotherien, so zeichnete sich auch $M$. bavaricum nicht durch die bizarre Gorilla-artigen 
Körperproportion aus, sondern ähnelt dem generellen Körperbauplan anderer zeitgleicher schizotheriner Krallentiere auf anderen Kontinenten, wie z.B. Moropus aus Nordamerika. $M$. bavaricum ist geringfügig kleiner als die Typusart Metaschizotherium fraasi von Koenigswald, 1932 (MN6MN7) und unterscheidet sich davon nur in geringem Maße, wobei die Abgrenzung zwischen morphologischer Variation und tatsächlichen Unterschieden zwischen den beiden Arten weiterer Untersuchungen bedarf. Das schizotherine Krallentier von La Grive St.-Alban (Frankreich), das von Koenigswald (Palaeontographica, Beitrage zur Naturgeschichte der Vorzeit 8:1-24, 1932) und Viret (Nouvelles Archives Musée d'Histoire Naturelle de Lyon 6:53-81, 1961) zu M. fraasi gestellt wurde, sollte neuerlich untersucht und möglichweise einer anderen Art zugeordnet werden.

Schlüsselwörter Metaschizotherium bavaricum . Sandelzhausen - Chalicotherien - Schizotheriinae . Moropus · Ancylotherium · La Grive · Miozän

\section{Introduction}

Members of the Chalicotherioidea (Mammalia, Perissodactyla) are among the most fascinating but uncommon mammals found in the Cenozoic of Eurasia, North America, and Africa. So far, approximately ten species worldwide are represented by relatively complete material. Additional valid species are recognized on the basis of distinctive craniodental or postcranial remains but lack significant parts of the skeleton. Further, many faunas yield just a few specimens-some teeth, an astragalus, a metapodial, or several phalanges - that can be identified to some level but for which specific or even generic identification is problematic. Early to Middle Miocene faunas of Europe have occasionally produced such fragmentary specimens, but placing them has been difficult without more complete comparative material. As a result, an important gap exists in our understanding of chalicothere evolution in this region.

In 1966 chalicothere dental and jaw material was first excavated from Sandelzhausen, near the town of Mainburg in Bavaria, Southern Germany. Originally attributed to Chalicotherium (family Chalicotheriidae, subfamily Chalicotheriinae) by Fahlbusch and Gall (1970), this chalicothere was later recognized as belonging to a member of the subfamily Schizotheriinae (Coombs 1974, Fig. 1; Fahlbusch 2003). Personnel from the Institute for Paleontology (University of Munich) and Bavarian State Collection, Munich, began a systematic excavation of the Sandelzhausen fossil site in 1969, and additional chalicothere specimens were unearthed and continued to appear through sustained fieldwork in 1969-1975 and 1994-2001. The Sandelzhausen chalicothere specimens represent different parts of multiple individuals, thus collectively allowing the characterization of much of the skeleton, and provide a potential comparative base to help identify more fragmentary remains from other localities. The material is also important to the understanding of the Sandelzhausen paleofauna and of chalicothere evolution and geographic distribution.

\section{Materials and methods}

The material presented here is housed in the Bavarian State Collection for Paleontology and Geology (BSPG), Munich, under the collection numbers BSPG 1959 II xxxxx. Complete collection numbers are listed in Tables 1 and 2, but numbers in the text are given without the prefix BSPG 1959 II.

Institutional abbreviations: ACM, Amherst College Museum of Natural History, Amherst; AMNH, American Museum of Natural History, New York; BMNH, British Museum of Natural History, London; BSPG, Bayerische Staatsammlung für Paläontologie und Geologie, Munich; BSPG/IPW, now Bayerische Staatssammlung für Paläontologie und Geologie, Munich, formerly stored at the Geologisch-Paläontologisches Institut der Universität Würzburg, Würzburg; CM, Carnegie Museum of Natural History, Pittsburgh; CMK, Community Museums of Kenya, Nairobi; FAM, Frick American Mammals, American Museum of Natural History, New York; IGME, Instituto Geologico y Minero de España, Madrid; LMJ, Landesmuseum Joanneum Graz, Austria; MHNL, Muséum d'Histoire Naturelle de Lyon, Lyons; MTA, Maden Tektik ve Arama Enstitüsü, Museum, Ankara; NHMW, Naturhistorisches Museum Wien, Vienna; NMA, Naturmuseum Augsburg, Augsburg; PA, PG, Palaeontological and Geological Museum of Athens, Athens; SMNS, Staatliches Museum für Naturkunde, Ludwigsburg/Stuttgart; UCMP, University of California Museum of Paleontology, Berkeley.

Abbreviations of institutions for tabular material drawn from published literature are omitted here but can be found in the respective cited papers.

Dental abbreviations: i/I, lower/upper incisive; $\mathrm{p} / \mathrm{P}$, lower/upper premolar; m/M, lower/upper molar.

\section{Geology and biochronology}

The fossiliferous deposits at Sandelzhausen and the excavations there have been described in detail by Fahlbusch (1976, 2003), Fahlbusch and Liebreich (1966), and Fahlbusch et al. (1972). In brief, the Sandelzhausen fossil site lies in the limnofluviatile Upper Freshwater Molasse, in the center of the North Alpine Foreland Basin, near Mainburg, about 
Table 1 Relative lengths and widths of Sandelzhausen and other Eurasian schizotheriine upper cheek teeth

\begin{tabular}{|c|c|c|c|c|c|c|c|c|c|c|c|}
\hline Specimen & $\begin{array}{l}\text { P3 } \\
\text { length }\end{array}$ & $\begin{array}{l}\text { P3 } \\
\text { width }\end{array}$ & $\begin{array}{l}\text { P4 } \\
\text { length }\end{array}$ & $\begin{array}{l}\text { P4 } \\
\text { width }\end{array}$ & $\begin{array}{l}\text { M1 } \\
\text { length }\end{array}$ & $\begin{array}{l}\text { M1 } \\
\text { width }\end{array}$ & $\begin{array}{l}\text { M2 } \\
\text { length }\end{array}$ & $\begin{array}{l}\text { M2 } \\
\text { width }\end{array}$ & $\begin{array}{l}\text { M3 } \\
\text { length }\end{array}$ & $\begin{array}{l}\text { M3 } \\
\text { width }\end{array}$ & Comments \\
\hline \multicolumn{12}{|l|}{ M. bavaricum } \\
\hline \multicolumn{12}{|l|}{ Sandelzhausen } \\
\hline BSPG 1958 II 2507 & 18.6 & 20.3 & 21.1 & 23.4 & 30.1 & 25.6 & 38.6 & 31.4 & 41.0 & - & \\
\hline BSPG 1959 II 11613 & 18.0 & 18.6 & & & & & & & & & \\
\hline BSPG 1959 II 11610 & 17.9 & 21.4 & & & & & & & & & \\
\hline BSPG 1959 II 11628 & 18.4 & 21.6 & & & & & & & & & \\
\hline BSPG 1959 II 11573 & 19.5 & 20.1 & 21.8 & 22.8 & & & & & & & \\
\hline BSPG 1959 II 11621 & & & & & & & 37.5 & 29.5 & & & \\
\hline BSPG 1959 II 11571 & & & & & & & 35.5 & 29.6 & & & \\
\hline BSPG 1959 II 11612 & & & & & & & 35.5 & 29.6 & & & Could be M3 \\
\hline BSPG 1959 II 11624 & & & & & & & 36.0 & - & & & Broken \\
\hline BSPG 1959 II 11614 & & & & & & & & & 37.9 & & Could be M2 \\
\hline BSPG 1959 II 11630 & & & & & 29.1 & 25.7 & & & & & \\
\hline \multicolumn{12}{|l|}{ Häder and Stätzling } \\
\hline \multicolumn{12}{|l|}{ From von Koenigswald (1932) } \\
\hline NMA 457/1915 (Häder 1903) & & & & & 31.0 & 25.5 & & & & & \\
\hline NMA 92 553/761 (Häder 1898) & & & & & & & 37.5 & 32.0 & & & \\
\hline NMA 86-372 & & & 20.0 & 20.0 & & & & & & & \\
\hline \multicolumn{12}{|l|}{ Viehhausen (BSPG/IPW): } \\
\hline From Rinnert (1956) & 19.0 & 21.5 & & & & & & & & & \\
\hline \multicolumn{12}{|l|}{ M. fraasi } \\
\hline \multicolumn{12}{|l|}{ From von Koenigswald (1932) } \\
\hline SMNS 5351 & & & & & & & 43.5 & 33.0 & 41.0 & 35.0 & \\
\hline SMNS 4851 & & & & & & & 46.0 & 36.0 & & & Original of Fraas (1870) \\
\hline Basel Sth 701 & & & & & 32.0 & 26.0 & & & & & \\
\hline Tübingen & 17.0 & & 22.0 & 25.0 & & & & & & & \\
\hline SMNS 9861 & 18.0 & 21.0 & & & & & & & & & \\
\hline \multicolumn{12}{|l|}{ La Grive } \\
\hline \multicolumn{12}{|l|}{ Schizotheriine } \\
\hline MNHL 3121 & & & & & & & & & 53.3 & 44.5 & Could be M2 \\
\hline MNHL 3113 & & & & & & & & & 48.6 & & Could be M2 \\
\hline MNHL 1006 & & & & & & & & & 46.5 & 44.7 & Could be M2 \\
\hline MNHL 1007 & & & & & & & 50.4 & 38.7 & & & Could be M3 \\
\hline MNHL 1001 & & & & & & & 45.4 & 38.1 & & & \\
\hline MNHL 1002 & & & & & 37.5 & 32.8 & & & & & \\
\hline \multicolumn{12}{|l|}{ Phyllotillon naricus } \\
\hline \multicolumn{12}{|l|}{ Bugti, Pakistan } \\
\hline BMNH M12159 & 20.6 & 21.4 & 21.2 & 25.0 & $\sim 33.5$ & 32.7 & 47.5 & 35.3 & & & Quite worn \\
\hline BMNH M12161 & 21.9 & 21.6 & & & & & & & & & P4 ID by Forster-Cooper (1920) \\
\hline BMNH M12160 & 23.6 & 22.3 & 24.3 & 25.2 & & & & & & & Moderately worn \\
\hline BMNH 12163 left & & & & & & & & & 43.7 & 36.3 & \\
\hline BMNH 12163 right & & & & & & & 41.0 & 33.3 & 41.8 & 35.9 & Isolated upper teeth \\
\hline BMNH M12162 & & & & & & & & & 48.3 & 38.2 & Little worn \\
\hline
\end{tabular}

Measurements in $\mathrm{mm}$

$70 \mathrm{~km}$ north of Munich. The Sandelzhausen fossil Lagerstätte has produced a good 50,000 identifiable but generally disarticulated specimens (Fahlbusch 2003). There are five perissodactyl species, including three rhinocerotids, a horse, and the chalicothere described herein. Heissig (1997) included the Sandelzhausen fauna in a biostratigraphic study of the 


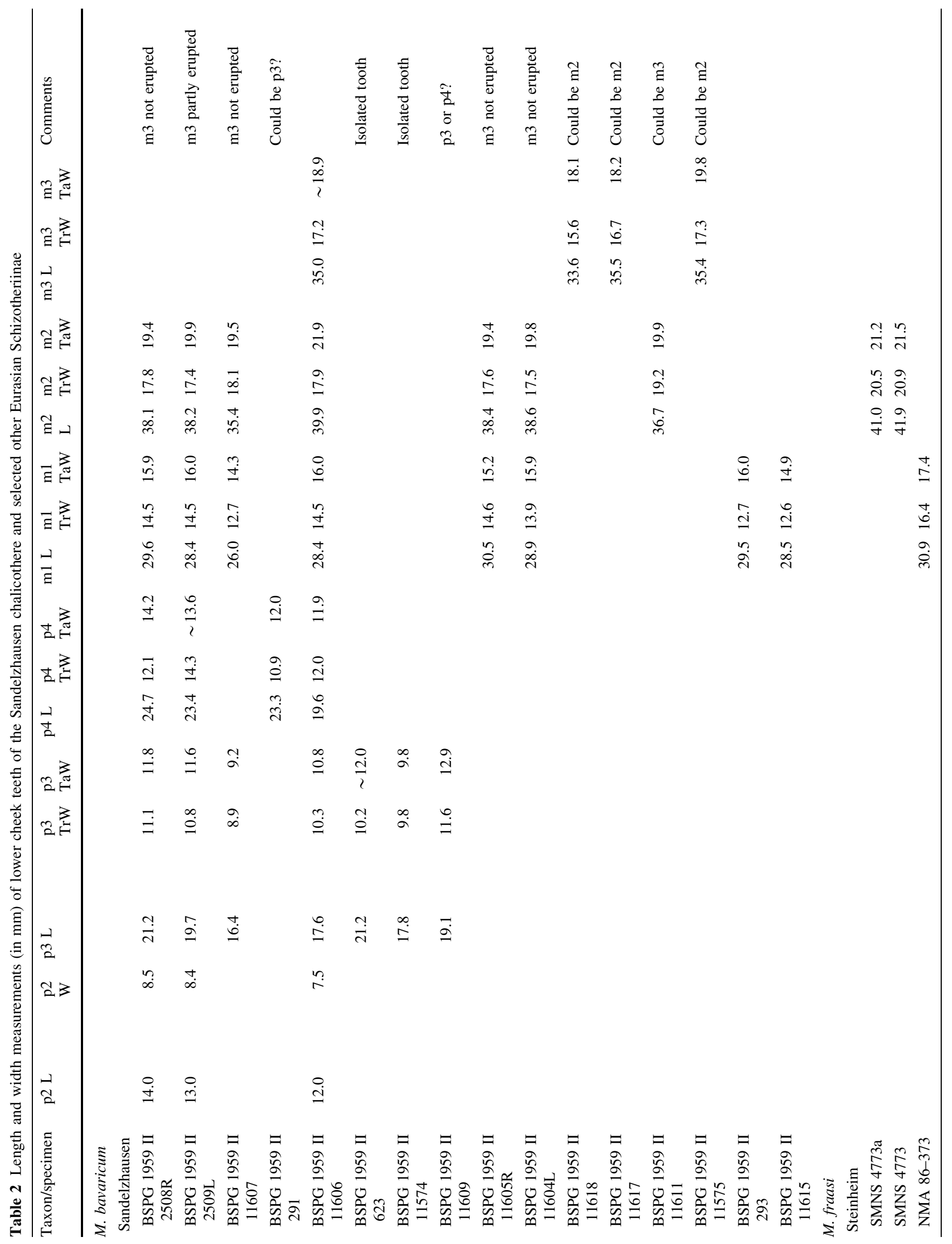




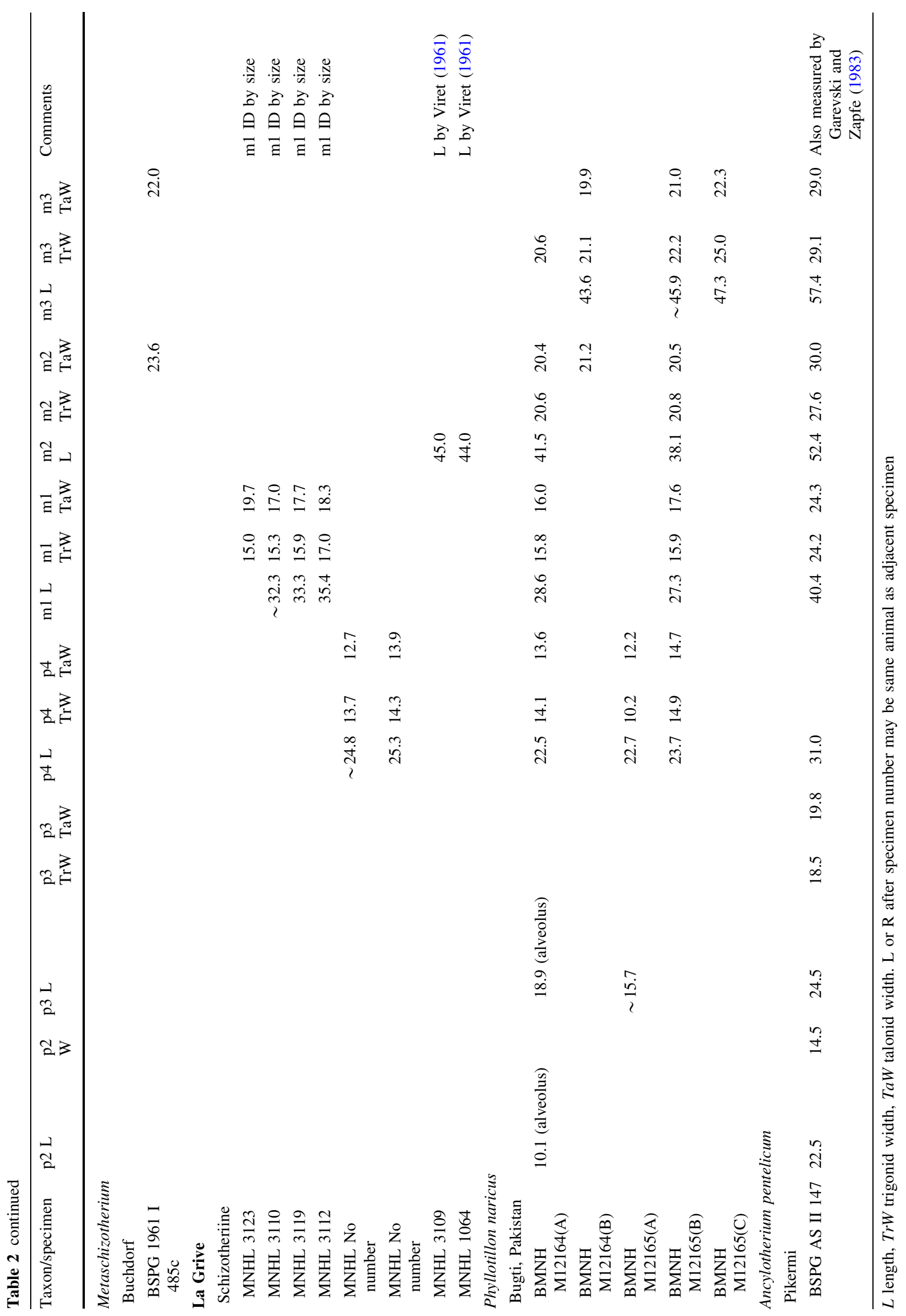


mammalian faunas from the Upper Freshwater Molasse of Bavaria. He placed the Sandelzhausen fauna in the early Middle Miocene (MN5 = European Mammal Neogene Unit MN5, Badenian) and interpreted the absolute age as approximately $16 \mathrm{Ma}$. Based on recent bio-, litho-, and magnetostratigraphic investigations the stratigraphic position of the locality, Sandelzhausen, is situated at or very close to the Early/Middle Miocene boundary (Karpatian/Badenian boundary) (Moser et al. 2009).

The fossil-bearing section consists of gray to olive-colored marly sediments of $3 \mathrm{~m}$ maximum thickness, underand overlain by sand and gravel. The lower half of the section includes a humus-enriched brown-colored layer 10$35 \mathrm{~cm}$ thick containing a thin lignitic coaly ("Kohle," but not true coal) layer. Fossils are concentrated around the lignitic layer (Fahlbusch and Liebreich 1996), and the in situ stratigraphic position of many specimens is recorded in terms of proximity to the lignitic layer. Field information for most of the fossils allows them to be placed in one of five stratigraphic layers, designated by the letters A-E (Fahlbusch and Gall 1970; Fahlbusch et al. 1972; Fahlbusch 1976; Fahlbusch and Liebreich 1996). Layer C represents the lignitic layer, $\mathrm{A}$ the base, and $\mathrm{E}$ the unfossiliferous uppermost layer. In the case of the chalicothere remains, 76 specimens have sufficient field data to determine the layer from which they came. Of these, $10(13 \%)$ came from layer A, $44(58 \%)$ from B, 12 (16\%) from C, and 10 (13\%) from D. In some cases subdivision information within layers is available; for example, 18 of the 44 chalicothere elements from layer B are clearly from its lowest part, B1; many of these are larger bones. Results showing a concentration in layer B are consistent with those for other relatively large mammals, such as rhinocerotids and proboscideans, found at Sandelzhausen (K. Heissig, U. Göhlich, pers. comm.).

The systematic excavations at Sandelzhausen divided the horizontal area into $1 \mathrm{~m}^{2}$ quadrants designated by numbers south to north and letters east to west (Fahlbusch and Gall 1970). Later excavations were added on the east side of the original excavations with the new (NB) quadrants designated by letters from west to east (Fahlbusch 2003). In mapping out the quarry distributions of chalicothere specimens for which quadrant coordinates are available, I found that, although chalicothere remains are spread through many parts of the quarry, they are concentrated in two areas: "Grabungstelle Mitte" (in a rectangle delineated by $\mathrm{L}-\mathrm{P}$ and 12-29) and the new NB area (in the rectangles NB A-G, 11-16, and NB S-Z, 5-19.

\section{Systematic paleontology and morphology}

Class Mammalia

Order Perissodactyla
Superfamily Chalicotherioidea Gill, 1872

Family Chalicotheriidae Gill, 1872

Subfamily Schizotheriinae Holland and Peterson, 1914

\section{Metaschizotherium von Koenigswald, 1932}

\section{Revised diagnosis}

Medium-sized schizotheriine chalicotheriid in which the proximal and middle phalanges of both digit II of the manus and pes are fused to form a duplex bone. Cheek teeth relatively low-crowned for a schizotheriine. Incipient hypocone and large lingual cingulum present on P4. No crochet present on upper molars. Well-developed metastylid on lower molars; metastylid sometimes present on $\mathrm{p} 4$. Manus plesiomorphic compared to Ancylotherium in retaining a free trapezium, volar process on the lunate, disto-volar hook on the magnum, and metacarpals with rounded rather than flattened shafts. Mc II derived in having its length somewhat shortened compared with shaft width. Astragalus asymmetrical with fibular side low, and weak development of neck.

Included species

M. fraasi (type species), M. bavaricum, and possibly M. wetzleri.

\section{Comments}

Metaschizotherium, as named by von Koenigswald (1932), included schizotheriine chalicotheres from Steinheim am Albuch (Germany), Häder (Germany), and La Grive St. Alban (France). The material from Steinheim was originally referred to Chalicotherium antiquum Kaup, 1833 by Fraas (1870), and that from La Grive to Macrotherium grande var. rhodanicum by Depéret (1892). Steinheim is currently aged at MN7 and La Grive at MN7/8, while Häder is MN5, very close in age to the Sandelzhausen fauna (Heissig 1997, 1999a).

Rinnert (1956) referred chalicothere material to Metaschizotherium from the Oberpfalz brown coals of Viehhausen (Germany); Ziegler (1999) has given the age of Viehhausen as MN5. Additional BSPG material referable to Metaschizotherium is known from Stätzling (MN6; Heissig 1999a), Friedberg, Thannhausen (MN6; Heissig 1999b), and Buchdorf. Julia Fahlke (University Bonn, pers. comm.) also recognizes Metaschizotherium from fissure fill deposits at Petersbuch 71 (MN6) and from several additional German localities. Single skeletal elements potentially referable to Metaschizotherium have also been figured from the Austrian localities of Kaisersteinbruch 
(Zapfe 1967; MN7/8), Krems (Zapfe 1974; MN9), and Holzmannsdorfberg (Mottl 1966; Coombs 1974).

Though best known in Europe, Metaschizotherium may extend into Asia, though remains are fragmentary. Kaya et al. (2001) recently figured a proximal phalanx of a chalicothere from the late Orleanian/early Astaracian (=MN5/6) fauna of Kultak (Milas-Mugla), Southwestern Turkey, and referred this specimen to Metaschizotherium. Colbert (1934, Figs. 13a, d, f, misidentified as Macrotherium brevirostris) illustrated specimens of a schizotheriine chalicothere from Tunggur (Nei Mongol, China; MN7/8 equivalent according to Qiu et al. 1999). Although Late Miocene in age, the East African chalicothere named Chemositia tugenensis by Pickford (1979) also shows similarities to Metaschizotherium as well as Moropus (Coombs 1989). All these specimens must be considered in any discussion of the geographic range of Metaschizotherium.

von Koenigswald (1932) named two species of Metaschizotherium: M. fraasi, exemplified by material from Steinheim and La Grive, and M. bavaricum, exemplified by material from Häder and Stätzling. Dietrich (1942) named Metaschizotherium hennigi from Africa, but this species was removed and renamed Ancylotherium hennigi by Thenius (1953) and Butler (1965). Recently Fejfar et al. (1997) placed Chalicotherium wetzleri (Kowalewsky, 1873) within Metaschizotherium as M. wetzleri. This species is primarily known from lower jaws with teeth from Germany (Eggingen and Michelsberg near Ulm, MN2; Heissig 1999a). Fejfar et al. (1997) added several upper cheek teeth to Metaschizotherium wetzleri from the Czech Republic (Merkur-Nord, MN3a). Although these authors gave no morphological reasons for referring this species to Metaschizotherium, M. wetzleri does represent a schizotheriine, not a chalicotheriine, chalicotheriid and needs to be considered in any discussion of the evolution of Early Miocene European Schizotheriinae.

The status of the genus Metaschizotherium is intrinsically related to our understanding of the schizotheriine genera Phyllotillon, Moropus, and Ancylotherium. Phyllotillon naricus Pilgrim (1910) is based on dental and jaw material and fused phalanges from the Late Oligocene of Bugti (Pakistan). Viret (1949) suggested that Metaschizotherium was a junior synonym of Phyllotillon, a conclusion also adopted by Butler (1965). As a consequence, various Early Miocene schizotheriine remains from France, Spain, and Portugal have been attributed by some authors to Phyllotillon, but they now need to be compared with the extensive new comparative material of Metaschizotherium from Sandelzhausen. Another complication arises from the presence in Europe of Early Miocene postcranial material that suggests the presence of the genus Moropus, more typically found in North America (Coombs 1974). The possibility of Moropus in Europe is less surprising when one considers the presence of other mammalian taxa, such as the ursid Cephalogale, the amphicyonids Cynelos and Ysengrinia, and the rhinocerotid Menoceras, in Early Miocene faunas on both continents (Hunt 1998, 2002; Ginsburg 1999; Heissig 1999b; Tedford et al. 2004). Kaya (1993) also made a case for the presence of Moropus in Turkey.

At the other end of its temporal range, Metaschizotherium has sometimes been synonymized with the genus Ancylotherium Gaudry (1862). Thenius (1953) first proposed this synonymy and was followed by Zapfe (1967, 1974) and Coombs (1974), both of whom retained Metaschizotherium as a subgenus of Ancylotherium, thus Ancylotherium (Metaschizotherium). The emphasis in the comparisons was the type species $M$. fraasi and fragmentary postcranial materials from Kaisersteinbruch and especially Krems (Austria) that show derived characters in common with the well-known Turolian schizotheriine species Ancylotherium pentelicum. Coombs (1974) listed the following derived characters in common between M. fraasi and A. pentelicum: development of a distinct crochet on upper molars, ectoloph on upper molars flatter between styles and not so deeply W-shaped as in Moropus (i.e., slightly higher crowned), P4 often with incipient hypocone, lunate with strongly reduced palmar process, and cuboid with transversely broadened distal facet for Mt IV. These characters, which were based on limited material of Metaschizotherium, are reevaluated and discussed in the present paper in view of the more complete Sandelzhausen material.

Heissig (1999a) took the position that Metaschizotherium represents a distinctive Central and Western European lineage that underwent increasing dental specialization from M. wetzleri to M. fraasi but then disappeared. He noted a temporal, morphological, and geographic gap between Metaschizotherium and Ancylotherium and concluded that Ancylotherium was part of a new Upper Miocene immigration wave that lived in more sparsely wooded peri-Mediterranean faunas exemplified by Pikermi (Greece) but never penetrated Central Europe.

\section{Metaschizotherium bavaricum von Koenigswald, 1932}

Type material

A left M1 (NMA 457/1915 = Häder 1903) and right M2 (NMA 92 553/761 = Häder 1898) from Häder (Southern Germany) were described, measured, and figured (pl. 1 Figs. 4,5 ) as the index material of this species by von Koenigswald (1932). He also illustrated (pl. 1, Fig. 13) and measured a left P4 (NMA 86-372) from Stätzling (Southern Germany). He did not designate a single 
specimen as the holotype from among this material. I have examined all this material at the Naturmuseum Augsburg.

Additional material of von Koenigswald (1932)

A duplex (fused proximal and middle phalanges) from Häder, figured by von Koenigswald (1932, pl. 2 Fig. 22) as belonging to the manus of "Chalicotherium" grande, actually belongs to digit II of the pes of $M$. bavaricum. This specimen, NMA 86-356-761, closely resembles no. 11562, a duplex of digit II of the pes from Sandelzhausen.

\section{Diagnosis}

Body size smaller on average than $M$. fraasi. $\mathrm{P} 4$ hypocone better developed than in M. fraasi. Strong hypocone present on M3. Upper molar protocones smaller and more pointed than in $M$. fraasi. Astragalus with prominent tibiovolar process.

\section{Comments}

von Koenigswald (1932) mentioned the following characters in his informal diagnosis of M. bavaricum: smaller size, less-developed upper molar protocone, and a stronger $\mathrm{V}$-shape of the anterior part of the upper molar ectoloph. A fuller diagnosis of $M$. bavaricum awaits complete description of new material referable to $M$. fraasi and a better understanding of the status of M. wetzleri. For the present, designation of generic versus species-level diagnostic characters is difficult.

\section{Description}

\section{Upper dentition}

Aside from a small number of broken maxillae associated with upper cheek teeth, no skull material attributable to the Sandelzhausen chalicothere has yet been identified. No upper incisors or canines are known, but these teeth have usually been lost in schizotheriine chalicotheriids (Coombs 1978a) and most likely were not present in this animal. There are some specimens of upper premolars, molars, and deciduous premolars, but only two specimens associate two or more upper teeth: 2507, a left maxilla with P3-M3 (Fig. 1a), and 11573, right P3-P4 (Fig. 2b).

Both P1 and p1 are lost in Chalicotheriidae (Coombs 1989). No specimens of $P 2$ of the Sandelzhausen chalicothere are known. P3 and P4 are generally similar, though P3 is smaller (Table 1) and slightly simpler in morphology. There is little morphological variation among the four specimens of $\mathrm{P} 3$ and between the two specimens of $\mathrm{P} 4$. On
Fig. 1 Upper and lower cheek teeth of M. bavaricum from Sandelzhausen: a BSPG 1959 II 2507, left P3-M3 in occlusal view; b BSPG 1959 II 2508, right mandibular ramus with p2-m3 (m3 unerupted) in buccal view; c and d BSPG 1959 II 2509, left mandibular ramus with $\mathrm{p} 2-\mathrm{m} 3$ in buccal and occlusal views. Bars $2 \mathrm{~cm}$. These specimens most likely belong to a single individual along with the symphysis shown in Fig. 2a

$\mathrm{P} 3$ and $\mathrm{P} 4$ the paracone and metacone are of subequal height, though one or the other may be slightly taller. The parastyle is larger than the metastyle; there is no mesostyle, so the ectoloph is nearly flat, not W-shaped. Wear on the ectoloph is much stronger than on the protoloph, metaloph, and protocone, all of which begin to wear relatively late. Both the protoloph and metaloph are well developed and, when worn, wear about equally. There is a noticeable paraconule on the protoloph, especially on $\mathrm{P} 4$. The protocone has a second lower cusp posterior to it, to which the metaloph connects. This second cusp, which is more prominent on $\mathrm{P} 4$, is apparently an incipient hypocone. A ridge descends from the buccal side of the protocone into the fully enclosed central valley. Antero-lingual, lingual, and postero-lingual cingula are pronounced and give the lingual side of the tooth a more squared appearance. On P4, these prominent cingula form a completely separate ridge around the lingual cusps.

While M2 and M3 are about the same size, M1 is notably smaller (Table 1). The upper molars are not particularly high-crowned and thus have a lingually slanted ectoloph. As in other schizotheriine chalicotheriids, the ectoloph shows some elongation between the parastyle and mesostyle, but this elongation is modest in the Sandelzhausen material. There is a slight buccal ectoloph rib opposite the paracone and (if at all) only the merest trace of such a rib opposite the metacone. None of the molars has any trace of a crista or crochet. The protocone is pointed and tends to be unworn, as wear reaches this part of the tooth very slowly. A ridge from the antero-lingual cingulum ascends to the protocone tip. A paraconule is clearly visible on the protoloph, though it becomes less visible as wear proceeds lingually along the protoloph. The hypocone is well developed and is incorporated into the metaloph; it has no accessory cuspules at its base. The postfossette is closed off by the posterior cingulum. On M3 the metaloph has its buccal origin well removed from the mesostyle, even when this tooth is little worn.

Three upper deciduous teeth are available, one representing a probable DP3 and the other two probable DP4s (Fig. 2c). Of the latter, one highly worn probable DP4 is associated with 2507 and may represent a shedding or shed tooth; P4 of this specimen is unworn and just short of fully erupted. The deciduous premolars are very similar to permanent molars but show wear that is starting to reach the protocone. In the most worn example both buccal and lingual surfaces of the tooth are nearly obliterated. 

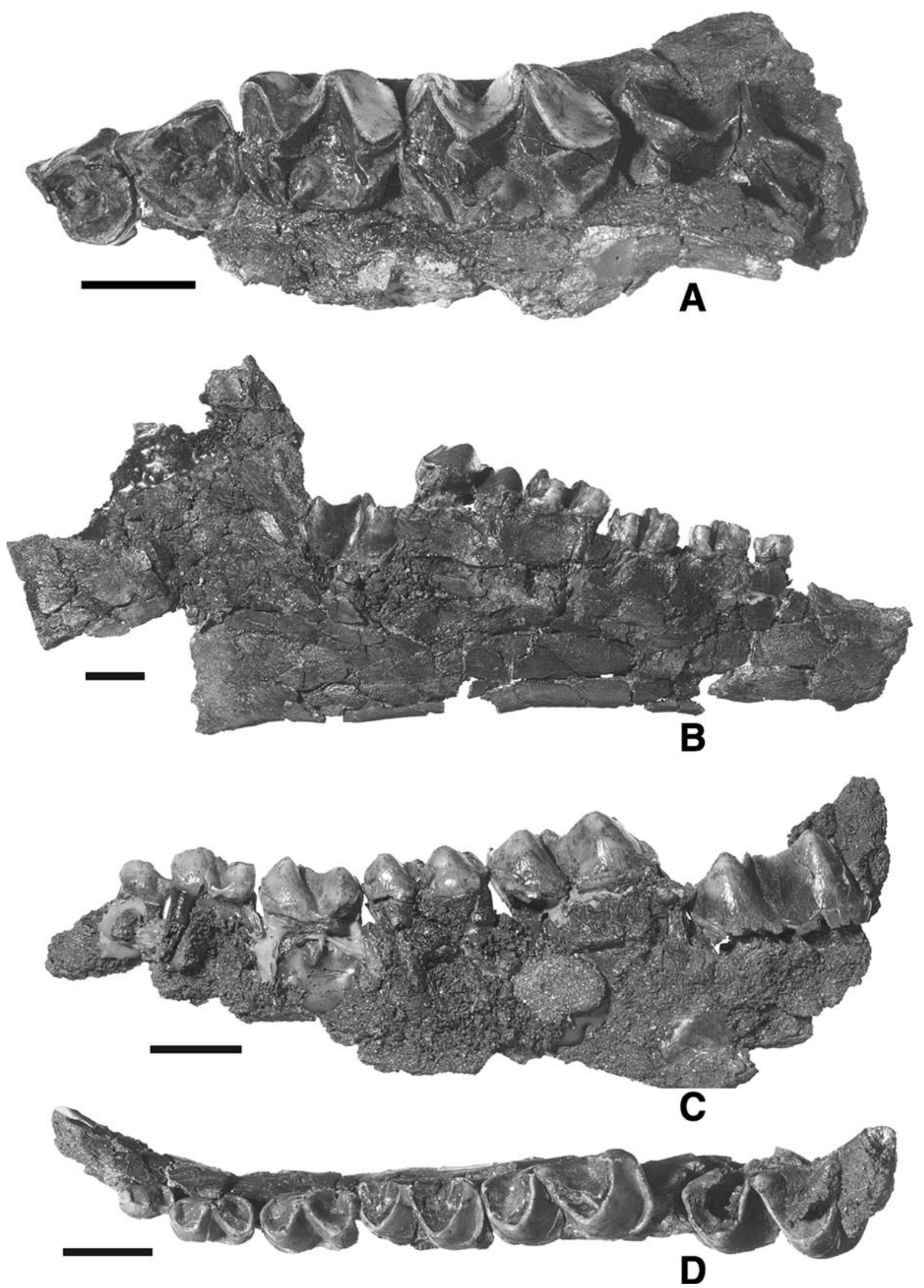


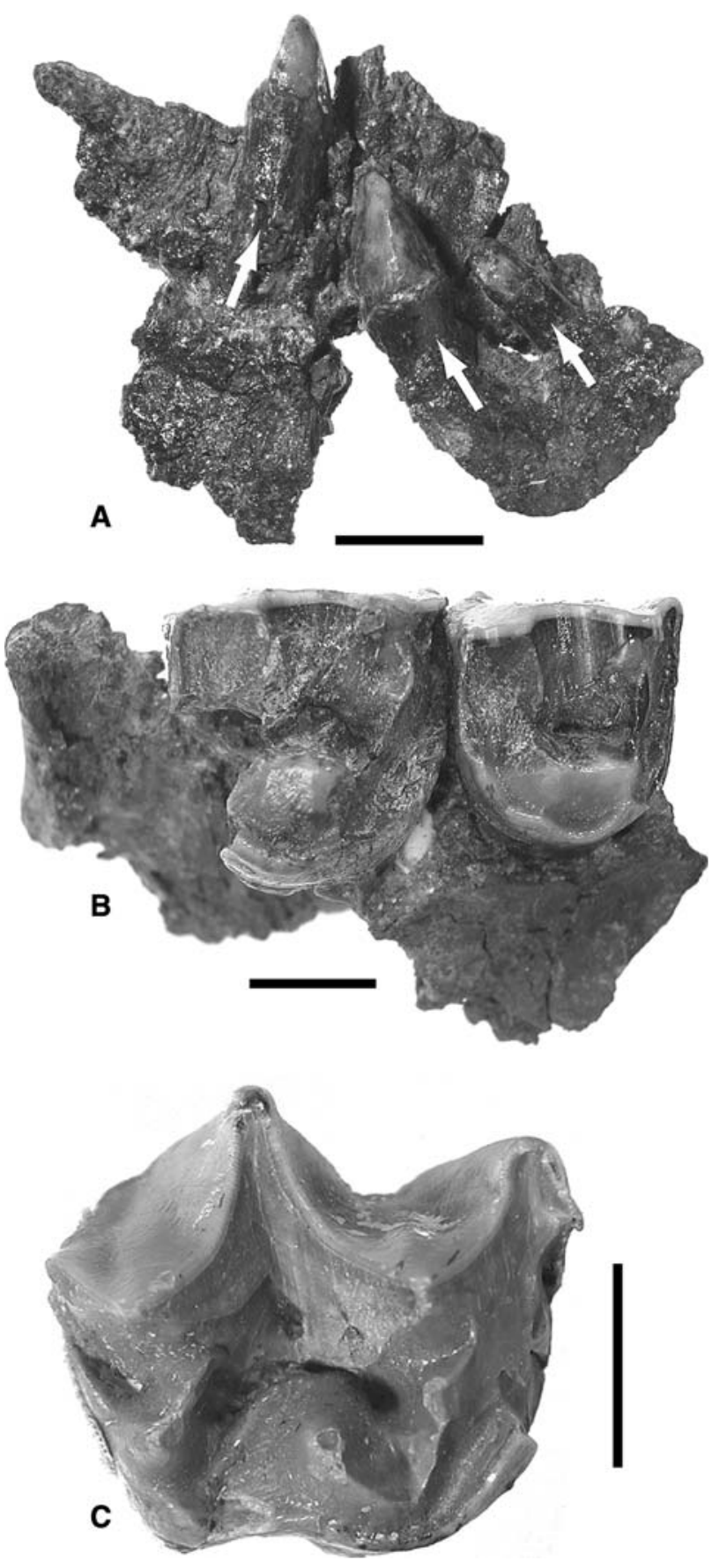

Fig. 2 Additional dental material of M. bavaricum from Sandelzhausen: a BSPG 1959 II 2508/2509, anterior view of mandibular symphysis showing reduced lower incisors, especially i3, at right (arrows indicate the bases of the preserved incisors); b BSPG 1959 II 11573, occlusal view of right P3-P4; c BSPG 1959 II 11572, occlusal view of right probable DP4. Bars $1 \mathrm{~cm}$

\section{Lower dentition}

Lower incisors are preserved in only one specimen from Sandelzhausen, no. 2508/2509. A group of three lower incisors is preserved, at least two of them in alveoli, separate from the remainder of the lower jaw (Fig. 2a). It is not clear whether these incisors are all one side or a combination of left and right, so it remains uncertain whether there were two or three incisors on a side. One of the incisors, possibly i3, is tiny and peg-like, while the other two are a bit larger and more flattened. None of them shows any wear. There is no evidence of a lower canine. This specimen was collected along with the maxilla no. 2507 and paired mandibles nos. 2508 and 2509; all are probably part of the same individual.

In the following description of lower teeth, the term metastylid is used for the lingual cusp adjacent and posterior to the metaconid. Hooker (1994) observed that perissodactyls lose the true metastylid early in their evolution and that the cusp often called a metastylid in more derived taxa is actually formed by twinning of the metaconid. The terminology here is not intended to contradict Hooker but to maintain, for the sake of consistency, the traditional usage.

Several specimens preserve the lower cheek teeth of the Sandelzhausen chalicothere (Table 2). It is thus possible to observe some variability in lower premolar morphology. The $\mathrm{p} 2$ is known from three teeth belonging to two individuals. In nos. 2508 (right; Fig. 1b) and 2509 (left; Fig. 1c, d), little-worn examples of both sides, likely of one individual, are preserved. The right $\mathrm{p} 2$ of no. 2508 shows the proportionally longest version of this tooth: the paraconid, protoconid, and hypoconid are subequal in height and connected by a slightly lower antero-posterior lophid. The left p2 of no. 2509 is similar but relatively shorter, and 11606 is shorter still. A small lophid descends lingually from the hypoconid of $\mathrm{p} 2$, but no separate entoconid is visible. The $\mathrm{p} 3$ and $\mathrm{p} 4$ range from quite molariform (nos. 2508/2509, 291, 623) to much less so (nos. 11606, $11574,11619,11607)$, and in general the less molariform teeth are also shorter. The paraconid and entoconid are more prominent on relatively molariform teeth, while these cuspids are little separated from accompanying lophids on less molariform teeth. Less molariform examples tend to have a lower talonid and a more oblique buccal groove coming from the trigonid/talonid junction. The metastylid is more visible as a separate cuspid in the more molariform examples, but it is always visible to some extent (for example, in no. 11607), unless it has been worn down. More molariform examples show sharper apices of lophids meeting at the protoconid and hypoconid. Wear on $\mathrm{p} 3$ and p4 is likely to make these teeth look less molariform, but there are intrinsic differences; for example, the unworn $\mathrm{p} 3$ and $\mathrm{p} 4$ of no. 11607 are not very molariform.

Of the lower molars, $\mathrm{m} 1$ is by far the smallest, while $\mathrm{m} 3$ is close to but slightly smaller than $\mathrm{m} 2$. On the jaws with complete lower molar rows there is a preponderance of young individuals in which $\mathrm{m} 3$ is not completely erupted. Thus $\mathrm{m} 3$ may be hard to measure, but as a bonus the lack of heavy wear makes the teeth easy to study. In all cases the 
talonid is longer and broader than the trigonid. The lophids are fairly straight and meet at sharp apices at the protoconid and hypoconid; the paralophid is more curved than the other lophids. There is a well-developed metastylid, which is as tall as the metaconid on $\mathrm{m} 2$ and $\mathrm{m} 3$, though not always on $\mathrm{m} 1$. Lingual cingula are weak; there may be a slight lingual cingulum at the opening of the talonid basin on some specimens (especially $\mathrm{m} 2$ ). Antero-buccal and postero-buccal cingula are moderately developed, and there is some development of a buccal cingulum opposite the junction of the trigonid and talonid.

Only a few lower deciduous teeth are preserved, and none of these is found in a jaw. In their isolated condition they can sometimes be difficult to differentiate from the rather molariform permanent premolars.

No. 292 clearly represents a left dp3, on the basis of the long, anteriorly curved extension of the paralophid that is typical of this tooth in schizotheriine chalicotheres. This tooth has a clear metastylid that is a little lower than the metaconid.

\section{Mandibles}

Although no. 2508/2509 has the best preserved lower dentition among Sandelzhausen chalicothere specimens, the jaws themselves were poorly preserved and are held together only by extensive reconstructive effort. The betterpreserved right mandible (no. 2508) shows that the jaws were slender in width and increase in depth posteriorly and that the ascending ramus rises steeply posterior to $\mathrm{m} 3$. At $\mathrm{p} 2$, the cheek tooth row rises perceptibly above the diastema separating the cheek teeth from the incisors. Several other mandibles help to confirm the above information and add additional details. No. 11604 preserves both the ascending ramus and angular process, which expands below the lower edge of this jaw (Fig. 3a). No. 11605, which appears to represent the right mandible of the same individual, shows a mental foramen beneath the p3-p4 junction (Fig. 3b); whether any of the other jaws had a foramen in this location is not clear. The lingual side of this jaw also preserves the jaw symphysis, which ends well anterior to the alveolus for $\mathrm{p} 2$, and the beginning of the expanded angular process. No. 11607 also preserves a short symphysis and the p2 alveolus; its buccal side also shows a clear mental foramen about $21 \mathrm{~mm}$ anterior to the $\mathrm{p} 2$ alveolus, near the anterior end of the jaw. All of these mandibles represent young individuals, in which the eldest, no. 2508/2509, has an incompletely erupted $\mathrm{m} 3$. The other, ontogenetically younger, mandibles have clearly not yet reached full size.

Vertebrae and ribs

The BSPG Sandelzhausen collection includes a number of unallocated large vertebrae and ribs. In North America, especially in the Early Miocene, vertebrae and ribs of a large chalicothere, such as Moropus elatus, can readily be identified, because there were no other equally large animals in the fauna. At Sandelzhausen, several rhinos, a paleomerycid, and proboscideans also had large vertebrae and ribs. Therefore, identifying large ribs becomes extremely difficult, and only the more complete vertebrae are potentially identifiable. Two cervical vertebrae and a thoracic vertebra are the most likely candidates to belong to the Sandelzhausen chalicothere, but these elements do not yield much useful comparative information. An estimated $5 \%$ of the larger ribs and vertebrae from Sandelzhausen might be chalicothere but are too fragmentary or not clearly diagnostic. According to Kurt Heissig (pers. comm.), many ribs and vertebrae could not be collected at Sandelzhausen because their condition was too poor. For whatever reason, vertebrae and ribs are only modestly represented in comparison with expected numbers based on other identified chalicothere elements in the collection and the large number of vertebrae and ribs in a live articulated skeleton.

\section{Forelimb}

There are no complete forelimbs, but many separate elements are available. No scapular remains have been identified. Distal parts of two humeri (nos. 11635 and 11638) are clearly identifiable, and a few additional distal humerus fragments in the collection might belong to a chalicothere. The distal end of the humerus is strongly flared in both specimens and flexed slightly anteriorly compared with the distal shaft. Deformation of the posterior surface of the distal end of no. 11635 makes it somewhat difficult to determine the amount of anterior flexion, but careful examination of this specimen and of no. 11638, which is not deformed in the same way, confirms that some flexion does occur. The wide articular surface of the humerus is displaced laterally relative to the axis of the shaft (Fig. 4a, b). Thus, in anterior view, the broad capitulum (with which the radius articulates) lies lateral to the axis of the shaft. The narrower trochlea terminates anteriorly below the lateral side of the shaft, but its pulley then curves medially to its posterior end in the olecranon fossa, which is more or less directly in line with the shaft. The entepicondyle is very strong, as in other chalicotheres, in contrast to its condition in other perissodactyls. There is a well-developed ectepicondyle on the prominent lateral side of the distal end and a strong ectocondylar ridge (supinator crest) extending from it to the shaft. A bit of the deltopectoral crest is visible on the shaft near the proximal broken end of the bone, but it cannot be traced much farther distally. 

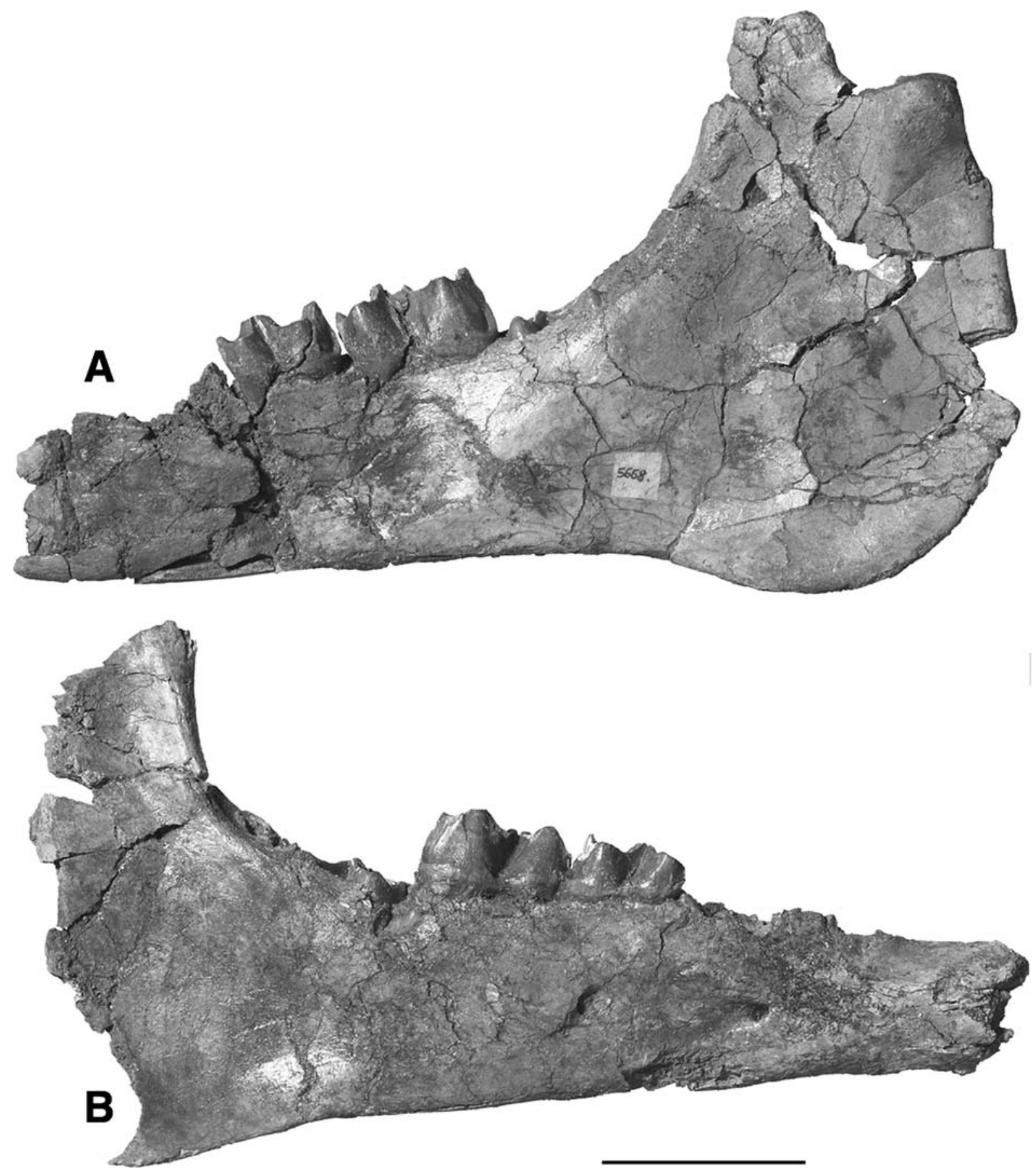

Fig. 3 Mandibular rami of M. bavaricum from Sandelzhausen: a BSPG 1959 II 11604 (left) and b BSPG 1959 II 11605 (right), both in buccal view. The visible teeth in each are $\mathrm{m} 1$ and $\mathrm{m} 2$, while $\mathrm{m} 3$ is just

There are three preserved ulnae: no. 11644 (proximal half to two-thirds; Fig. 4c), no. 11643 (almost complete, but damaged), and no. 11645 (proximal end; the largest of the three). None is perfect and all lack the distal end, but the articulations for the humerus and radius are partly to well preserved. As is characteristic for chalicotheres, the facet for the radius is deeply angled in from the semilunar notch beginning to erupt. These specimens most likely belong to a single young individual. Bars $5 \mathrm{~cm}$

Fig. 4 Long bones of the forelimb of M. bavaricum from Sandelzhausen: a BSPG 1959 II 11638, a humerus shaft and distal end, in anterior view; b BSPG 1959 II 11635, a distal humerus in anterior view; c BSPG 1959 II 11644, proximal end of ulna showing the articular surfaces for the humerus and radius; d BSPG 1959 II 11637 , proximal end and shaft of radius; and e BSPG 1959 II 11632, broken distal epiphysis of radius showing the articular surface for the scaphoid and lunate carpals. Bars $2 \mathrm{~cm}$ 


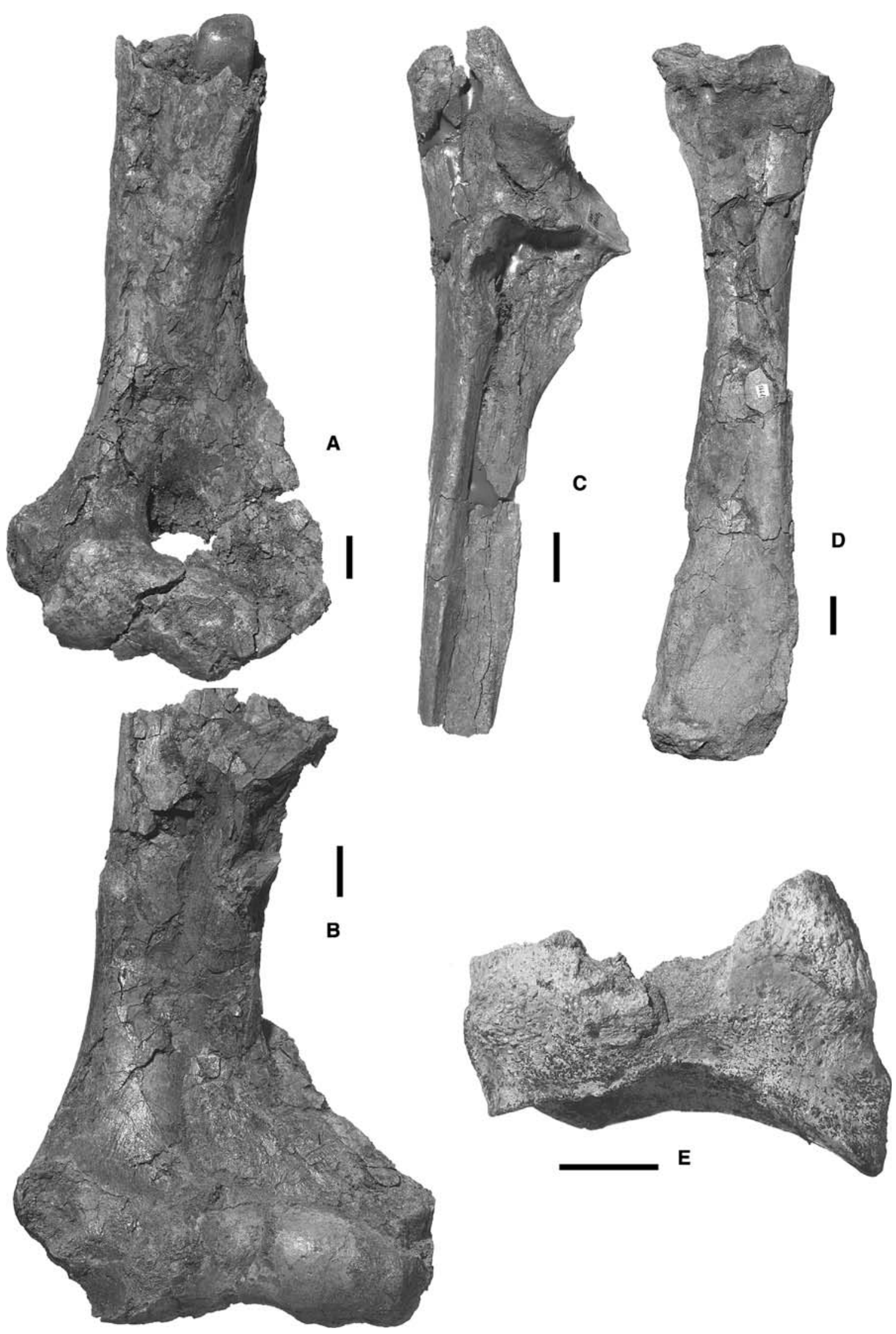



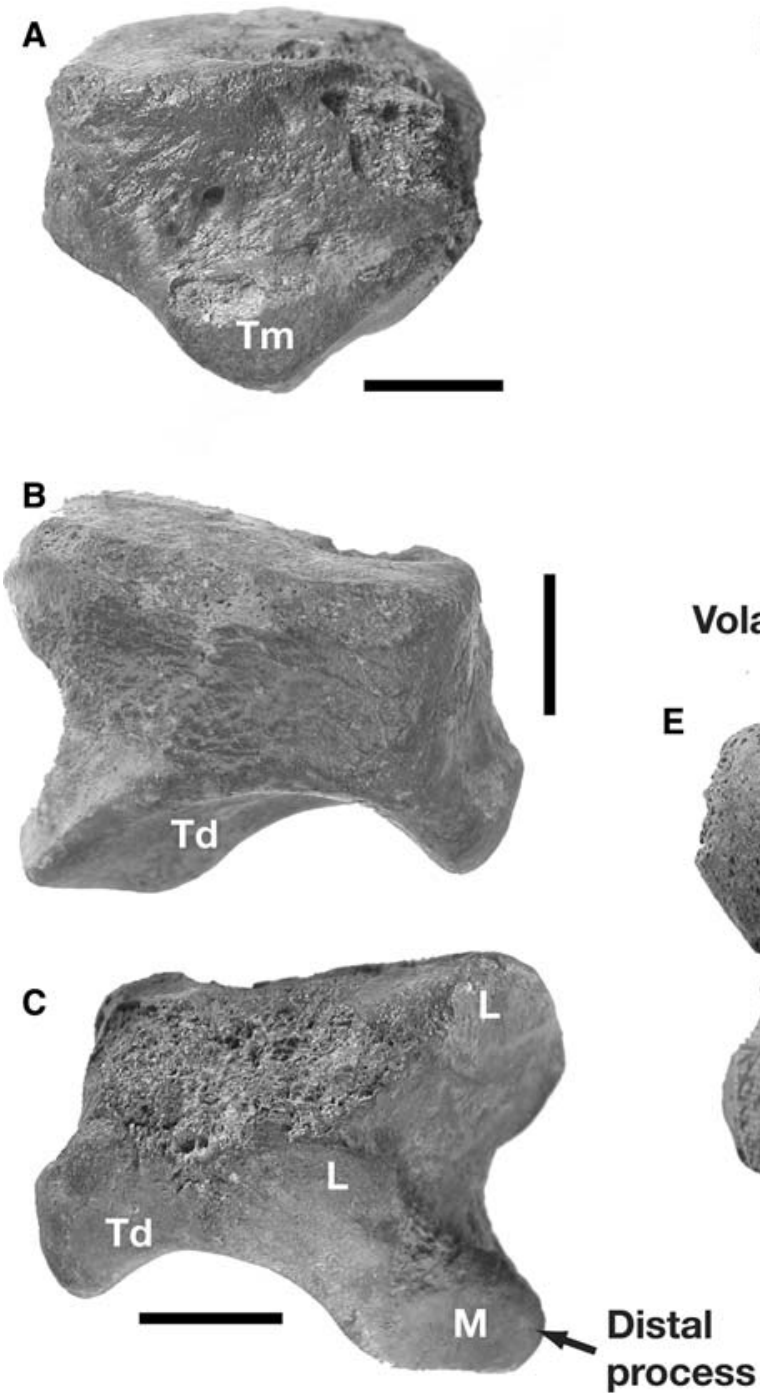

Fig. 5 BSPG 1959 II 11570, a right scaphoid and magnum of a small immature animal of $M$. bavaricum from Sandelzhausen. Scaphoid: a radio-volar, b dorso-radial, and $\mathbf{c}$ ulnar views. Magnum: $\mathbf{d}$ ulnar, e

(which forms part of the elbow joint against the humeral trochlea). The radius and ulna were not fused proximally, but rotation of the radius was not possible. The olecranon process is robust but not particularly long. The shaft of the ulna has a subtriangular cross-section and tapers distally.

Two radii, no. 11637 (Fig. 4d) and no. 11634, preserve the proximal end and part of the shaft. The facets for the ulna and humerus on the wide proximal end are fairly flat and not strongly delineated from one other. The shaft shows little torsion and does not broaden distally. Two specimens represent only the distal epiphysis of the radius: nos. 11632 (Fig. 4e) and 11589. Neither of these includes an associated distal ulna, though a large notch for its attachment is present. Facets for scaphoid and lunate carpals on the distal surface of the radius are continuous but readily distinguishable. The lunate facet is more concave,
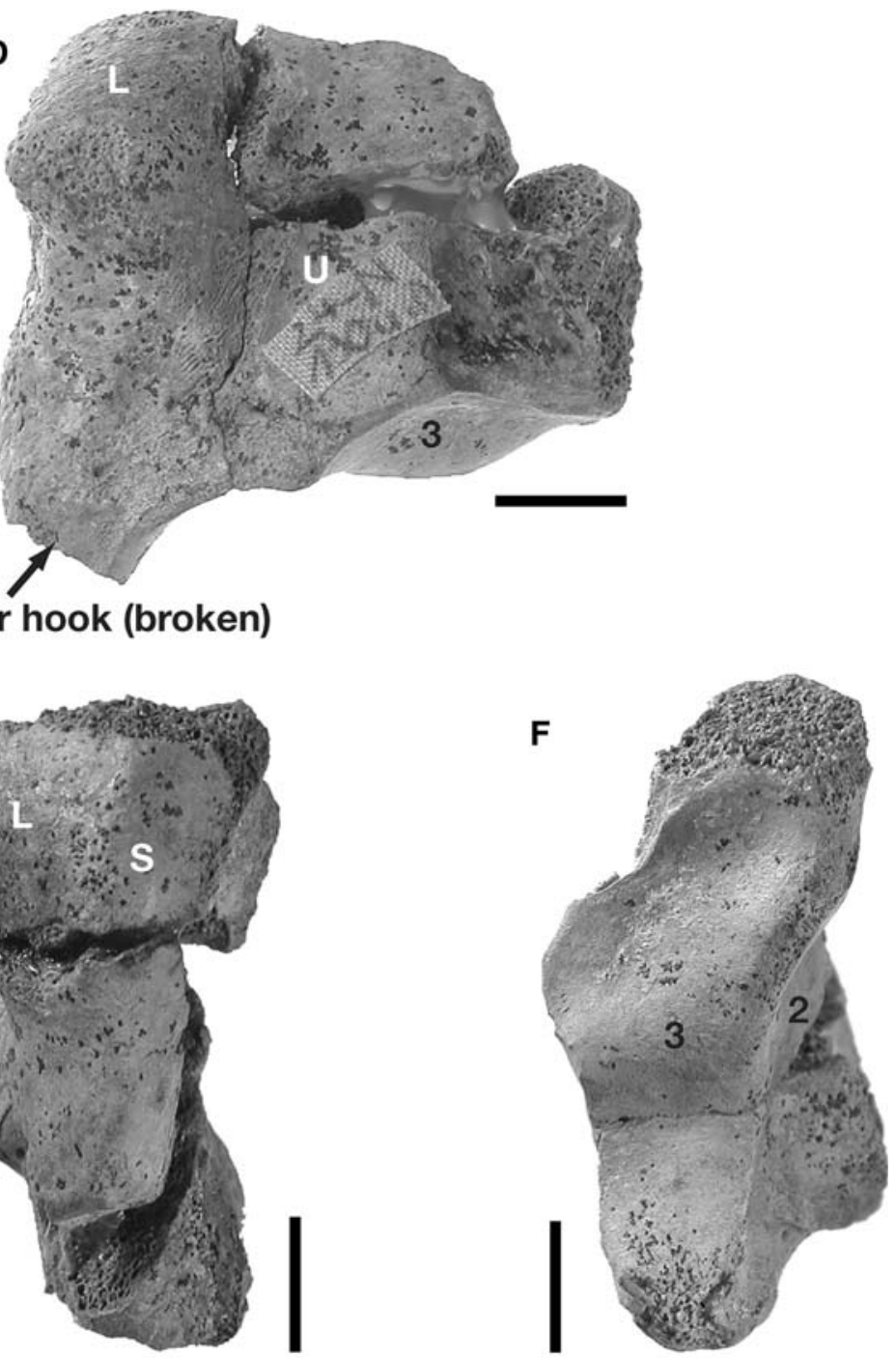

proximal, and $\mathbf{f}$ distal views. $T m$ trapezium, $L$ lunate, $M$ magnum, $T d$ trapezoid, $S$ scaphoid, $U$ unciform, 2 Mc II, 3 Mc III. Bars $1 \mathrm{~cm}$

conforming to the convexly rounded proximal surface of the lunate. Both facets, but especially the scaphoid facet, curve onto the ventral surface of the distal radius.

All of the carpals except the trapezium are represented, though only two appear to be associated (11570, the scaphoid and magnum of a small juvenile). The scaphoid (11570, Fig. 5a-c) shows a clear trapezium facet, helping to confirm the presence of this small, unpreserved bone. The distal process of the scaphoid has an oblique, unsquared articulation with the magnum. There are two facets for the lunate, but the more distal one is continuous with the magnum facet and thus difficult to distinguish from it.

There are three lunate specimens of different sizes (Fig. 6a-c): nos. 11563, 11564, and 11595. The proximal facet, articulating with the radius, is convexly rounded from its dorsal to volar edges. There are proximal and 
distal facets for the scaphoid, but the distal scaphoid facet is small. A well-developed volar (=palmar) process is present on the lunate and contains a large articulation on its distal surface for the magnum. However, this facet is more evenly concave than cup-like and is broadly continuous with the convex dorsal part of the magnum facet. A prominent ridge separates the magnum facet from the unciform facet; the unciform facet curves slightly onto the dorsal surface of the lunate, but the magnum facet does not, and its dorsalmost edge ends in an obvious ridge. Clear proximal and distal facets exist between the lunate and cuneiform; the more distal cuneiform facet is smoothly continuous with the unciform facet.

The single known cuneiform (no. 11556, Fig. 6g, h) is occupied on its dorsal proximal surface by a flat to slightly convex facet for the ulna. A much smaller pisiform facet, distinguished from the ulna facet by a weak diagonal ridge, occupies the volar part of the proximal surface of the cuneiform.

A single pisiform, no. 11596, is clearly identifiable (Fig. 6i). This small bone articulates with the cuneiform and ulna via tongue-like facets that meet at a sharp ridge and are slightly at an obtuse angle to one another. The concave facet for the ulna is angled slightly from a right angle to the pisiform shaft. The pisiform is relatively short, with the flat cuneiform facet extending over half the length of the bone. The short shaft is not transversely narrowed but bears a prominent longitudinal crest on the proximal side opposite to the cuneiform facet. There is a rugose ligament attachment area on the distal surface of the free (volar) end of the pisiform.

The unciform (=hamate), represented by nos. 11594 (broken) and 11565 (Fig. 6d-f), articulates proximally with the distal surface of the cuneiform. This facet curves strongly onto the ulno-volar surface of the unciform and continues well distad, suggesting that the unciform could flex substantially against the cuneiform. A clear ridge separates the proximal edge of the cuneiform facet with the complexly shaped lunate facet, which occupies the more dorso-radial part of the proximal surface of the unciform. The primary facet on the distal surface of the unciform articulates with Mc IV. This facet is abbreviated at its volar edge, because the unciform lacks an ulno-volar process (see Coombs 1978b, 28, Fig. 12B). A small tongue of the Mc IV facet angles onto the radial surface of the unciform. The facets for the magnum and Mc III on the radial surface of the unciform are clearly delineated and approximately the same size. There is a well-defined ridge between the facet for Mc III (radial surface) and that for Mc IV (distal surface).

No. 11570 (Fig. 5d-f) includes a broken juvenile magnum, the only specimen of this element available for the Sandelzhausen chalicothere. A volar hook is present, though its extent is uncertain because the tip is broken off. Because this bone articulates with so many others, its shape is very much affected by its facets for other bones; for example, the primary proximal facet on the magnum is for the lunate. Its dorsal part faces obliquely in the ulnar direction, but its volar part, which fits into the volar process on the lunate, is gently convex but not ball-shaped. Adjacent to the lunate facet, on its radial side, the scaphoid facet is more elongate than square, corresponding to the oblique rather than squared distal process on the scaphoid. The square unciform facet on the ulnar side corresponds in shape with its counterpart on the unciform. The radial surface of the magnum is damaged, and it is difficult to ascertain the shape of the trapezoid articulation. Most of the facet for Mc II lies in a long, radially oriented band, but this facet has a distally oriented expansion, whose extent is unclear because of breakage, at its end above the volar process. A long, slender facet for Mc III occupies the distal surface of the magnum, extending onto the volar process.

The trapezoid bone, represented by nos. 11559 and 11560 (Fig. 7), is easily recognized by its distal V-shape in dorso-radial view. The $\mathrm{V}$ fits into a similarly shaped concavity on Mc II. The radial part of the Mc II facet faces mostly distally and extends from the dorsal to the volar edge of the trapezoid. In contrast, the ulnar part of the Mc II facet is much shorter and has more of an ulnar orientation. There is no overhang of the dorsal surface of the trapezoid above the Mc II facet. In proximal view, the trapezoid is triangular with its longest axis on the ulnar side. An extensive, convex articulation, over which the scaphoid moved when the carpus was flexed, occupies the proximal and radio-volar surfaces of the trapezoid. There is a small depression in the dorsal part of the radial side for the trapezium. On the ulnar side of the trapezoid, the magnum articulated in a long proximal strip adjacent to the scaphoid facet. A small, more distal facet for the magnum abuts the Mc II facet at a right angle to its volar edge.

Of the metacarpals, multiple specimens of $\mathrm{Mc}$ II and Mc IV occur in varying states of preservation. There is no available specimen of Mc III from Sandelzhausen. Examination of Mc IV suggests that a small Mc V was present, but no specimens of this bone have been identified. The collection includes some additional distal metapodials that clearly belong to a schizotheriine chalicothere, but it is not possible to assign these fragments to particular digits.

The four specimens of Mc II include: nos. 11639 (same field number as 11638, a distal humerus), 11633 (proximal end), 11602 (same field number as no. 11603, Mc IV), and 11567 (proximal part; Fig. 8a-d). The dorso-radial edge of the proximal end has a broad M-shape, with its central $\mathrm{V}$ formed by the facet for the trapezoid. This facet passes all the way from the dorsal to the volar surface, becoming flatter in the volar direction. A clear facet for the trapezium 

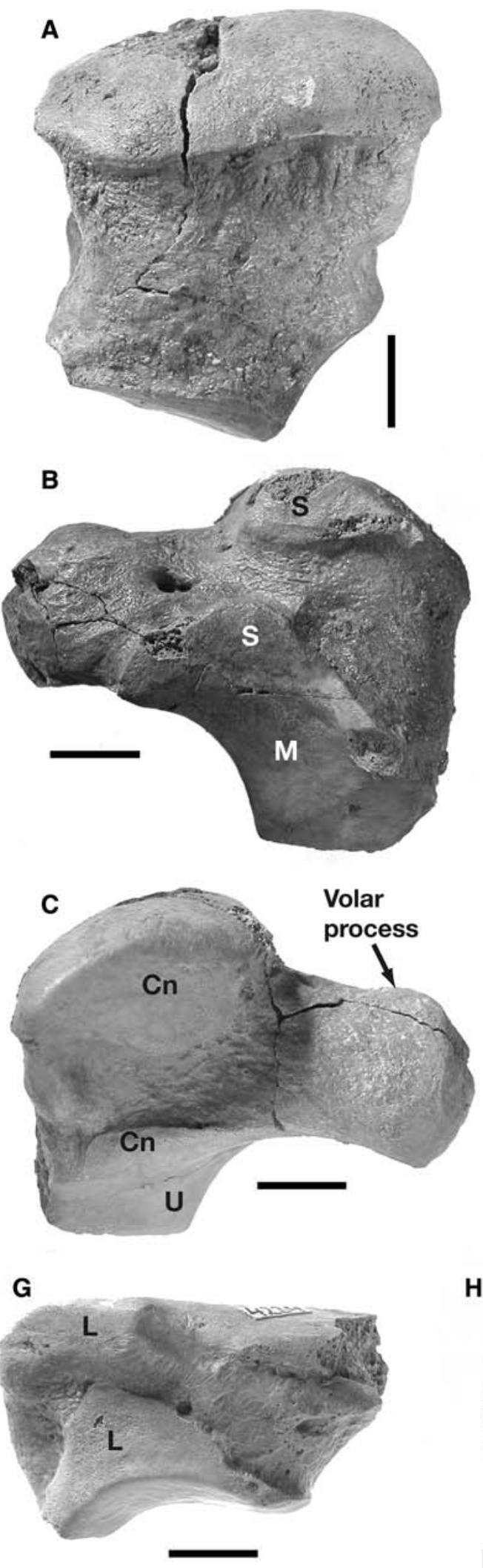
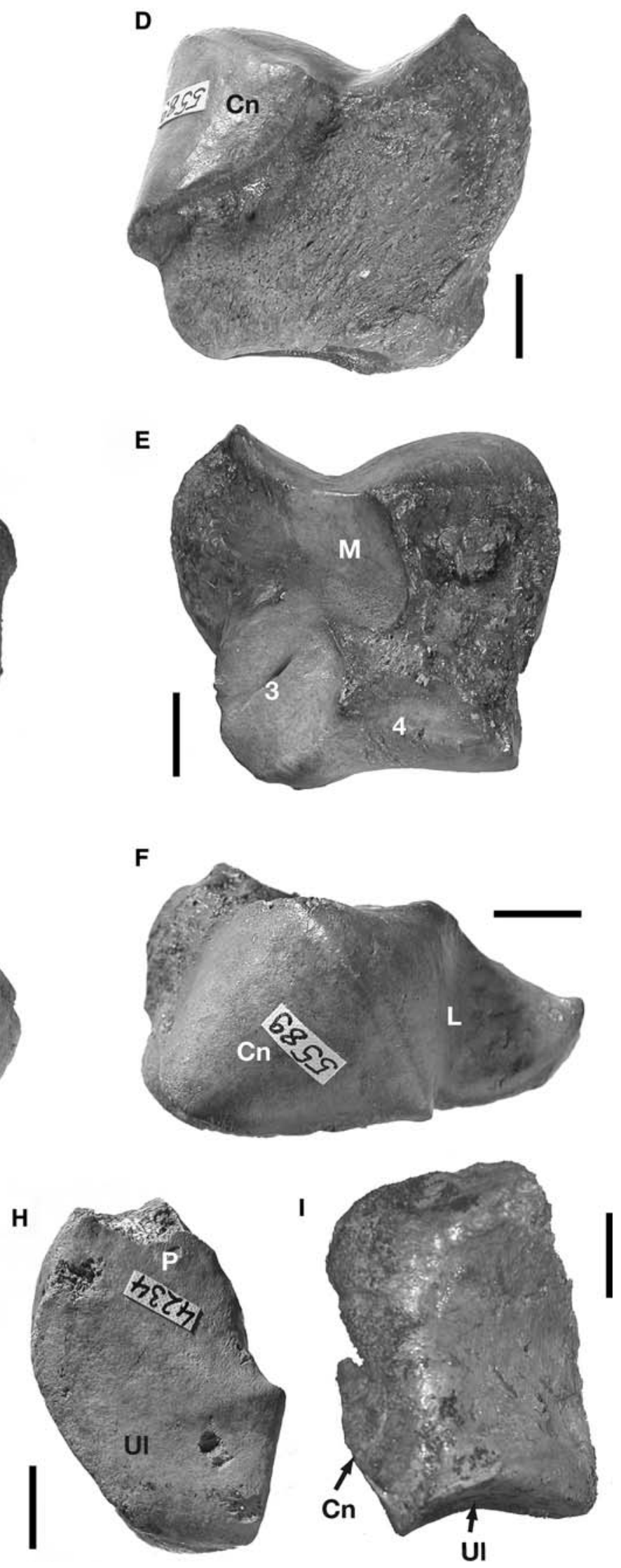
4 Fig. 6 Carpals of M. bavaricum from Sandelzhausen. a Dorsal, b radial, and c ulnar views of BSPG 1959 II 11563, a left lunate. d Dorso-ulnar, e radio-volar, and f proximal views of BSPG 1959 II 11565, a right unciform. $\mathbf{g}$ Radial and $\mathbf{h}$ proximal (dorsal at bottom) views of BSPG 1959 II 11556, a right cuneiform. i Radial view of BSPG 1959 II 11596, a pisiform. $S$ scaphoid, $L$ lunate, $C n$ cuneiform, $P$ pisiform, $U l$ ulna, $U$ unciform, $M$ magnum, $3 \mathrm{Mc} \mathrm{III,} 4 \mathrm{Mc}$ IV. Bars $1 \mathrm{~cm}$

occupies the radio-volar corner of the proximal end of Mc II, delineated by a ridge from the trapezoid facet. Two facets are present on the ulnar surface of the proximal end. The more proximal of the two is for the magnum. This facet adjoins and parallels the trapezoid facet; its dorsal part faces primarily in the ulnar direction, but its volar part has a more proximal orientation, corresponding to the shape of the counterpart articulation on the magnum. The concavely curved facet for Mc III is excavated below the adjacent magnum facet. In articulation it would cover part of the proximal surface of Mc III so that the dorso-radial and radial edges of Mc III would be hidden. As is typical of chalicotheriids, the shaft of Mc II shows torsion and the distal end is strongly asymmetrical. No. 11639 has the best preservation of the shaft, which is triangular to circular in cross-section.

There are three specimens of Mc IV: nos. 11603, 11598, and 11566 (Fig. 8h-j). At the proximal end the facet for Mc III forms a single long band curving from dorsal to volar. Mc III must have slightly overlain Mc IV dorsally, for the facet on Mc IV in that area has a dorsal orientation. The more volar part of the Mc III facet has a mostly radial orientation. Although the entire facet is continuous, there is a slight narrowing at the convex flex point of the two orientations. A ridge separates the Mc III facet from the transversely concave facet for the unciform, which occupies the proximal end of Mc IV; the unciform facet is narrowest at its dorsal edge and becomes wider in the volar direction. A deep depression on the volar surface of Mc IV, approximately $2 \mathrm{~cm}$ from the proximal end, marks the probable articulation of a vestigial $\mathrm{Mc} \mathrm{V}$, though there is no obvious articular surface and no $\mathrm{Mc} \mathrm{V}$ is known. The shaft of Mc IV tapers gently and has a rounded oval crosssection.

All phalanges, including those associated with the forelimb, are described after the hindlimb.

\section{Hindlimb}

The Sandelzhausen collection includes a number of large innominates in varying states of preservation. I could not identify any of these as clearly belonging to a chalicothere. There is one left femur, no. 11636, which is complete except for lacking the head and some of the greater and third trochanters (Fig. 9a). Despite the damage, it is clear that all of the trochanters were well developed. Longitudinal ridges connect the lesser trochanter with the head and the third with the greater trochanter. The asymmetrical development of the distal condyles is readily visible in posterior view. The patellar facet is more symmetrical, slender, and slightly oblique. Distal to the lesser and third trochanters the shaft tapers to its slenderest point and then gradually widens to the distal condyles. Length (not including the head) $=427 \mathrm{~mm}$; maximum distal width $=$ $109.3 \mathrm{~mm}$; minimum shaft width $=62.4 \mathrm{~mm}$.

There is no chalicothere tibia in the Sandelzhausen collection. Two patellae, nos. 11517 and 11516 (Fig. 9b, c), are available. The facet for the femoral trochlea has approximately equal height and width. The two sides of this facet meet almost perpendicularly along a blunt ridge. There is a strong ridge for the insertion of knee extensors on the proximal edge of the dorsal surface. A distal tongue occurs on the lower margin of the bone.

Three tarsals, the astragalus, calcaneum, and cuboid, are represented in the Sandelzhausen collection.

There are four astragali: nos. 11568 (Fig. 10a-c), 11600, 11599, and 11601. All are somewhat damaged, but together they give a reasonably good picture of this bone. There is a very short neck below the tibial side of the trochlea. The trochlea is quite asymmetrical, with its fibular cone much wider than the tibial one. The fibular side of the trochlea and its associated calcaneal facet on the volar surface hang distal to the neck. On the distal surface, the navicular facet is irregularly shaped and curves a short distance onto the tibial side of the bone. No facet for the cuboid is present. There is a notably prominent process at the tibio-volar corner of the distal end. On the volar surface, the ectal facet is not particularly deep, the sustentacular facet is nearly flat and irregularly shaped, and the calcaneal facet is slightly convex.

There are two preserved calcanea: nos. 11569 (Fig. 10d), which articulates well and may be associated with the astragalus 11568, and 11598, a fragmentary specimen. Neither specimen preserves the end of the tuber calcis, so the extent and rugosity of this process cannot be assessed. The ectal facet of the calcaneum is fairly wide but does not extend onto the sustentacular process; its two parts are bent convexly at a right angle to one another. Part of the ectal facet extends for a short distance onto the tuber calcis. In no. 11598 this part of the facet is raised above the tuber and there is a small facet for the tibia on its edge; no such facet occurs in no. 11569, where the ectal facet lies flatter on the tuber calcis. The ectal facet adjoins the calcaneal facet only at one corner and is separated from the sustentacular facet by an approximately $1-\mathrm{cm}$-wide groove. The sustentacular facet is large, rounded, and somewhat oblique. The distal surface of the calcaneum is occupied by the cuboid facet; breakage obscures the tibial extent of the 
Fig. 7 BSPG 1959 II 11559, a right trapezoid of M. bavaricum from Sandelzhausen. a Dorso-radial, b radio-volar, $\mathbf{c}$ ulnar, and d distal views. $S$ scaphoid, $T m$ trapezium, $M$ magnum, 2 Mc II. Bars $1 \mathrm{~cm}$

cuboid facet, but it does not appear to extend far, if at all, onto the sustentacular process.

There is a single specimen of a right cuboid, no. 11557 (Fig. 10e-g). The only facet on the proximal surface is that for the calcaneum; it tapers in the volar direction and ends well before the volar edge of the bone. When the cuboid is not articulated, the navicular facet is also clearly visible in dorsal view, reflecting the partly dorsal orientation of this facet. The main facet in distal view is that for Mt IV; it is roughly square-shaped. The ectocuneiform facet also forms a lengthy dorsal-to-volar band visible on the tibial side of the distal surface. This facet extends farther in the volar direction than any of the other facets. Notably, there is a small articular area, visible on the dorsal part of the distal and tibial surfaces and raised slightly from the contiguous Mt IV and ectocuneiform facets. This facet apparently articulated with Mt III. In tibial view the navicular, ectocuneiform, and Mt III facets are all visible, and a sharp dorsal-to-volar ridge delineates the navicular and ectocuneiform facets. The well-developed tibio-volar process occupies the volar part of the cuboid. This process angles slightly in the tibial direction and is most rugose on its distal surface.

No specimen of Mt II is known from Sandelzhausen. There is one Mt III, no. 11555, which articulates well with no. 11558, an Mt IV, and probably represents the same individual (Fig. 11a, e). This was a small, young individual. Both bones are broken off distally, so the various proportions involving metatarsal length used to compare them with other schizotheriine taxa cannot be used. Another specimen of Mt IV, no. 11597, preserves a damaged proximal end but little more.

A small bipartite facet for Mt II occupies the proximal edge of the tibial side of Mt III (Fig. 11b). Both parts of the facet have a tibial orientation and there is a thin connection between the two; the volar part of this facet is about twice as large as the dorsal part. The proximal surface of Mt III is almost completely occupied by a flat, tibially slanting, articular surface for the ectocuneiform. The dorso-fibular corner of the proximal end bears a clearly visible, small facet for the cuboid, corresponding to the similarly shaped facet already noted on the cuboid. This facet is visible in both proximal and fibular views (Fig. 11d, e). The Mt IV articular surface on the fibular side has two, approximately equal, parts connected proximally. The broken shaft of Mt III is oval rather than flat and shows no sign of thinning or flattening.
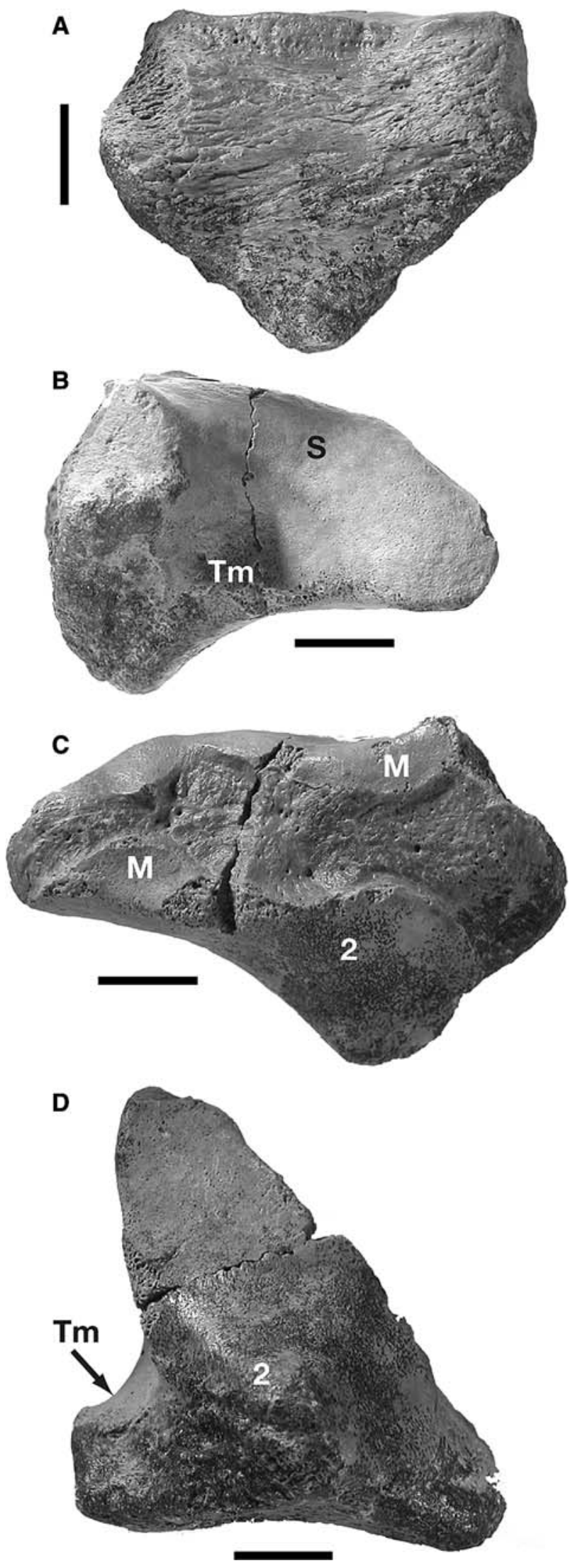
Mt IV articulates very tightly with Mt III, with little potential for movement between them, and there is no possible articular connection between Mt IV and the ectocuneiform. A sharp ridge delineates the larger, more dorsal part of the bipartite Mt III facet on the tibial side from the cuboid facet on the proximal surface (Fig. 11c). The smaller, more volar part of the Mt III facet is isolated by a depressed nonarticular area, except for a narrow connection with the dorsal part of the same facet. The cuboid facet is flat and broad, slanting somewhat distally in the fibular direction. The shaft of Mt IV narrows considerably distally, shows some torsion, and bears a longitudinal ridge along its dorso-fibular side.

\section{Phalanges}

Chalicothere phalanges in the Sandelzhausen collection include three fused proximal and middle phalanges (duplexes) of digit II of the manus, one duplex of digit II of the pes, five proximal phalanges, and six middle phalanges. Despite the ease with which the clawed ungual phalanges of chalicotheres can be recognized, no chalicothere ungual has yet been identified from Sandelzhausen.

No. 11561 (Fig. 12a-c) is the best preserved of the three manus duplexes but nonetheless shows some cracking and breakage. The proximal and middle phalanges are well fused, though some external traces of the original margins of the two bones remain visible. There is some degree of crookedness in the fusion of the bones, so their axes do not fall in a completely straight line; this feature is most easily recognized by looking at the angle between the distal articulation and the shaft of the bone. The concave articulation on the proximal end for Mc II is quite large and lies flat on the dorsal surface. This facet has a radial tongue (="ulnar tongue" of Coombs 1979; see comparisons below), and is bordered on its ulnar side by a ridge. The ulnar tubercle at the proximal end of the duplex is better developed than the radial one, though its extent is obscured by breakage. The articulation for the ungual phalanx at the distal end of the duplex suggests that the claw on this digit was enlarged, like that in other chalicotheres. This facet forms a trochlea extending from the distal surface well onto the volar surface. On the volar surface the sides of the trochlea become progressively raised above the surface and flared apart.

No. 11562 (Fig. 13a-c) represents the only Sandelzhausen duplex attributable to digit II of the pes. This duplex is much smaller than that of the manus, very symmetrical, and proportionately long and slender. The original proximal and middle phalanges retain pretty much their unfused proportions. The proximal facet (for Mt II) has a proximo-dorsal orientation, less strictly dorsal than its counterpart on the manus duplex. The distal facet is not large, and its corresponding claw was probably fairly small. Its trochlea is evenly curved relative to the more angular convexity of the trochlea of the manus duplex.

Proximal phalanges of the Sandelzhausen chalicothere include nos. 2510, 11584, 11585, 11586, and 11608 (Fig. 13d, e). The six available middle phalanges include nos. 2511, 11579, 11580, 11581, 11582, and 11609 (Fig. $13 \mathrm{f}-\mathrm{h}$ ). All of these phalanges are medium to small in size and generally similar in morphology. Most probably belonged to the pes, but it is very difficult to assign phalanges without an associated foot. Some of the middle phalanges, for example no. 11609, show strong development of a dorsal process that served as a stop to counter undue extension of the middle phalanx on the proximal phalanx.

\section{Comparisons}

In this section the Sandelzhausen chalicothere is compared with other derived Schizotheriinae (Fig. 14). Moropus elatus, Tylocephalonyx skinneri, and Ancylotherium pentelicum are the best-known taxa in this group and serve as a primary basis for comparison. Phyllotillon naricus is an important member of the comparison group because several authors (Viret 1949; Butler 1965) considered Metaschizotherium to be a junior synonym of Phyllotillon; unfortunately only dental remains and phalanges have been described or figured for P. naricus. Moropus merriami, a North American near contemporary of the Sandelzhausen chalicothere, is also included in some parts of the comparison.

Another major part of the comparison involves other, usually more fragmentary, materials of Schizotheriinae from other European localities (Table 3). The most important of these are specimens that have been attributed to Metaschizotherium fraasi or M. bavaricum at one time or another. These specimens are essential for determining the correct taxonomic designation for the Sandelzhausen chalicothere, the amount of morphological variation within the species of Metaschizotherium, and the relationship of this genus to other schizotheriine taxa. von Koenigswald (1932) and Viret (1961) attributed dental material of the schizotheriine chalicothere from La Grive (France) to M. fraasi. As the comparisons show, this attribution is probably erroneous, and the term La Grive schizotheriine is used here for that material. One important comparison is not included in this paper. Over the past several years, Dr. M. Rummel of the Naturmuseum Augsburg has excavated schizotheriine chalicothere material from karst fissure fillings of Petersbuch 71 (MN6) in the Franconian Alb of Germany. This material has been under study by Ms. Julia Fahlke, a graduate student at the Institut für Paläontologie 
der Universität, Bonn. I was able to see this excellent collection during the later stages of my study but do not include any detailed observations here. The Petersbuch collection includes some elements that have not been found at Sandelzhausen, such as the Mc III, tibia, navicular, mesocuneiform, Mt II, and some ungual phalanges. Further, there are multiple specimens from Petersbuch of some elements that are represented by only single bones from Sandelzhausen and some specimens that show interesting differences from their Sandelzhausen counterparts. I will make a few comments on the Petersbuch chalicothere in the taxonomic discussion. This collection shows much potential for continuing research.

Early Miocene isolated specimens of schizotheriine chalicotheres have been variously attributed to Moropus (Coombs 1974, 1989; Montoya et al. 1996), Phyllotillon (Antunes 1966; Belinchon and Montoya 1989-1990), and Metaschizotherium (Fejfar et al. 1997; Heissig 1999a). Fejfar et al. (1997) attributed "Chalicotherium" wetzleri (see Butler 1965, for background information on this taxon) to Metaschizotherium, thus M. wetzleri. Although further analysis of this assignment is needed, I use the name M. wetzleri in comparisons of this species, but do not include within it other Early Miocene European schizotheriine material. Several Middle to Late Miocene chalicotheres referred to Ancylotherium (Zapfe 1967, 1974) are also included in the comparisons. The significance of all the comparisons to our understanding of European schizotheriine chalicotheres is summarized in the taxonomic discussion.

\section{Upper dentition}

Comparison of the upper dentition is critical for understanding the relationships of the Sandelzhausen chalicothere to other Eurasian Schizotheriinae, because upper cheek teeth are the only common denominator for many of the taxa (Table 4). The associated P3-M3 of no. 2507 allows the opportunity for determining the relative proportions among teeth of a single individual. Although variation among the available Sandelzhausen upper teeth is not large (Table 1), this individual is at the larger end of the spectrum. Upper teeth of Metaschizotherium bavaricum (as measured by von Koenigswald 1932) and M. cf. wetzleri (as figured in Fejfar et al. 1997) are close in size to the Sandelzhausen material. Those of M. fraasi from Steinheim (as measured by von Koenigswald 1932) are at the upper end of the size range or are slightly larger, while specimens from La Grive are distinctly larger. Phyllotillon naricus is slightly larger, and Ancylotherium pentelicum much larger.

The upper premolars of the Sandelzhausen material most closely resemble P3 from Viehhausen (Oberpfalz Brown Coal; Rinnert 1956) and P4 from Stätzling (referred
Fig. 8 Metacarpals of Metaschizotherium. a-d Right Mc II of M. bavaricum from Sandelzhausen, BSPG 1959 II 11567. e-g Right Mc II of Metaschizotherium from Buchdorf, BSPG 1961 I 485a. h-j Right Mc IV of M. bavaricum from Sandelzhausen, BSPG 1959 II 11566. Views: a dorso-radial, b ulnar, c proximal, d volar, e dorsoradial, f ulnar, $\mathbf{g}$ proximal, $\mathbf{h}$ radial, $\mathbf{i}$ proximal, $\mathbf{j}$ ulno-volar. $\mathrm{Tm}$ trapezium, $T d$ trapezoid, $M$ magnum, $U$ unciform, $3 \mathrm{Mc}$ III, 5 ?Mc V (vestigial). Bars $2 \mathrm{~cm}$

to M. bavaricum by von Koenigswald 1932). Points of similarity include the strong wear on the ectoloph, the welldeveloped antero-lingual, lingual, and postero-lingual cingula, and incipient hypocone, especially on P4. A crushed premolar from Voitsberg (Austria; LMJ 1575, probably P3) also shows similar cingular development and a ridged protocone, possibly related to development of an incipient hypocone. The P3 from Steinheim referred to $M$. fraasi by von Koenigswald (1932) and P3 and P4 referred to $M$. cf. wetzleri by Fejfar et al. (1997) are also similar, though the resemblances there are more difficult to assess. Phyllotillon, Moropus, and Tylocephalonyx have conical or crescentic protocones on P3 and P4, but none of these shows an incipient hypocone. Ancylotherium pentelicum shows some degree of hypocone development on P3 and P4 but also has a crochet, which is lacking in the Sandelzhausen chalicothere.

The upper molars from Sandelzhausen resemble M. fraasi from Steinheim, M. bavaricum from Häder, and $M$. cf. wetzleri in not being particularly high-crowned. Ancylotherium pentelicum has the highest crowned upper molars of all Schizotheriinae. The La Grive schizotheriine also has quite high-crowned molars. Ancylotherium and the La Grive schizotheriine also have a well-developed crochet on the upper molars. The Sandelzhausen chalicothere does not display a crochet, nor does any known specimen of Moropus or Tylocephalonyx. Phyllotillon naricus occasionally shows a weak upper molar crochet. Assessing the presence of a crochet in M. fraasi from Steinheim is troublesome because of wear, but no crochet seems to be present there either. Upper molar material from Voitsberg (Austria; LMJ 1573, M2 figured by Bach 1912, pl. 28 Fig. 4, and referred with several other molar fragments to Phyllotillon (Metaschizotherium) sp. by Mottl, 1970) and from Anjou (France; referred by Ginsburg 1970, to Phylotillon aff. naricus and by Coombs 1974, to ?Moropus indet.) also lack any sign of a crochet. The buccal origin of the M3 metaloph of the Sandelzhausen chalicothere is not close to the mesostyle, even on unworn specimens. This is a relatively derived character in the Schizotheriinae, which can be seen in later species of Moropus such as M. merriami, and in Tylocephalonyx and Ancylotherium, but not in Schizotherium, Phyllotillon, and early species of Moropus (M. oregonensis, $M$. elatus). The well-developed hypocone on M3 of the Sandelzhausen chalicothere contrasts with the 


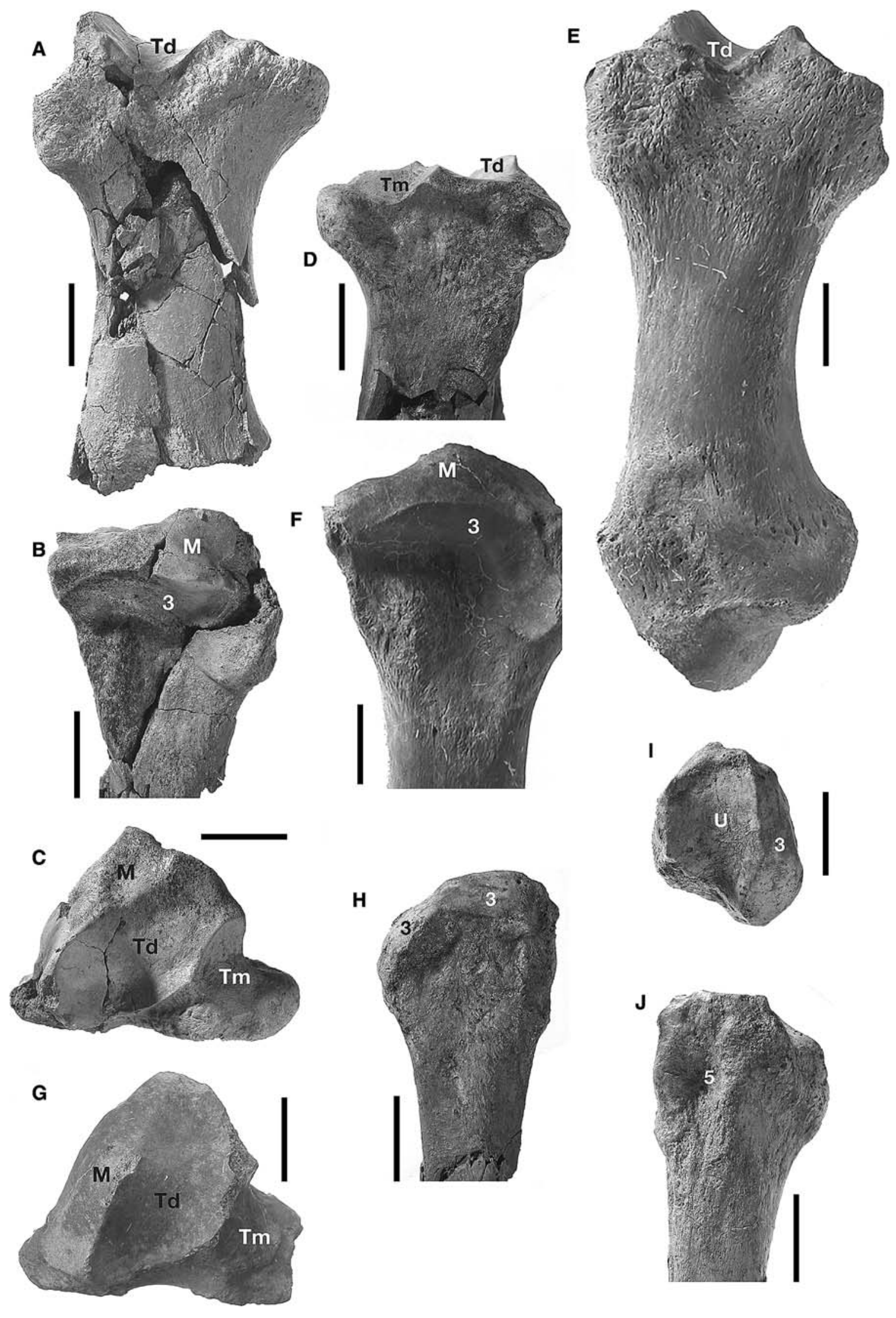




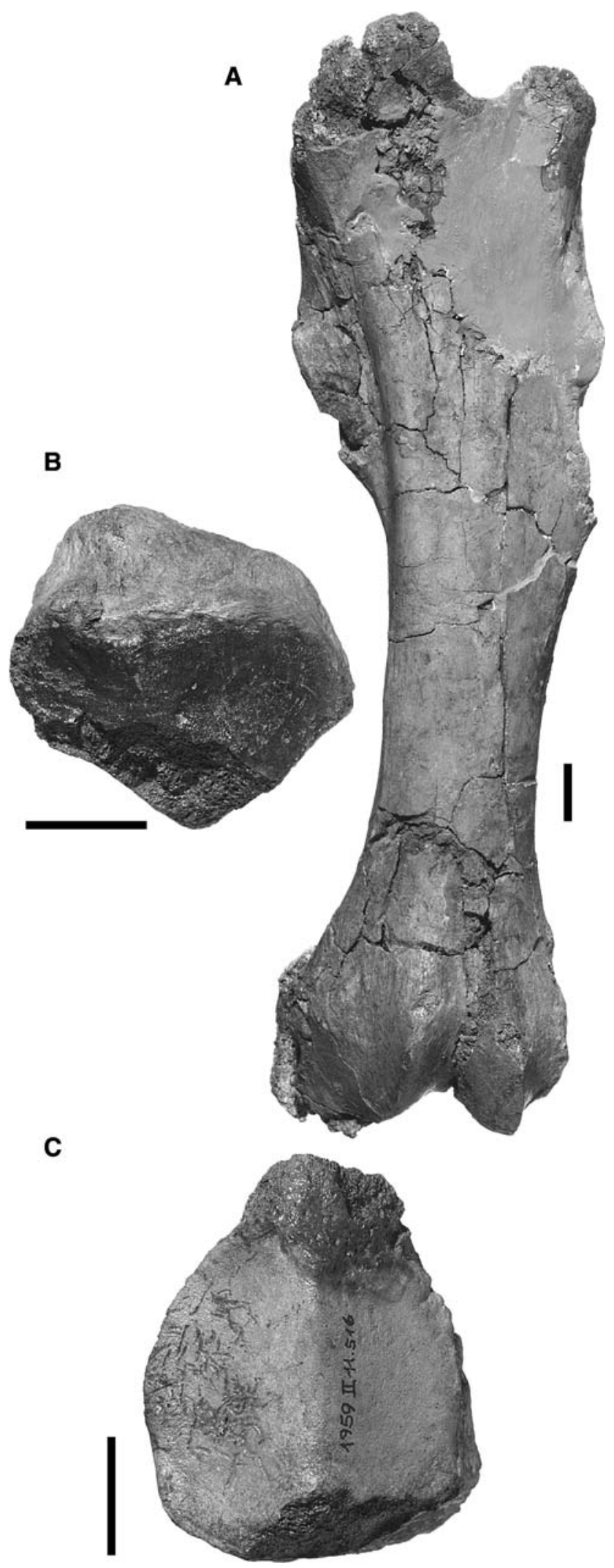

Fig. 9 Hindlimb elements of M. bavaricum from Sandelzhausen. a Anterior view of left femur, BSPG 1959 II 11636. b Proximal and c posterior (distal at top) views of patella, BSPG 1959 II 11516 . Bars $2 \mathrm{~cm}$
Fig. 10 Tarsals of $M$. bavaricum from Sandelzhausen. a Dorsal, b volar, and c distal views of BSPG 1959 II 11568, a right astragalus. d Dorsal view of BSPG 1959 II 11569, a right calcaneum. e Tibial, $\mathbf{f}$ proximal, and $\mathbf{g}$ distal views of BSPG 1959 II 11557, a right cuboid. Ectal ectal, $S$ sustentacular, and $\mathrm{Cl}$ calcaneal facets between astragalus and calcaneum, $\mathrm{Ca}$ calcaneum, $\mathrm{Ec}$ ectocuneiform, $\mathrm{N}$ navicular, 3 Mt III, 4 Mt IV. Bars $1 \mathrm{~cm}$

weak M3 hypocone in Ancylotherium pentelicum and Tylocephalonyx skinneri. Moropus and Phyllotillon also have a well-developed M3 hypocone, while that of Steinheim specimens of $M$. fraasi seems moderately developed. The M3 hypocone of the La Grive schizotheriine also appears moderately developed.

\section{Lower dentition}

While it is clear that the Sandelzhausen chalicothere had lower incisors, these incisors are much smaller than the well-developed spatulate incisors of Moropus elatus (Coombs 1978a, b). Alveoli on BMNH M12164 suggest that Phyllotillon naricus also had three good-sized lower incisors (but no canine, contra Forster-Cooper 1920). Tylocephalonyx has some incisor reduction, especially of i3 (Coombs 1979), but less than that of the Sandelzhausen chalicothere. Small incisor alveoli in a jaw referred to Moropus merriami (Coombs 2004) also suggest incisor reduction in this species. Of the schizotheriine chalicotheres that preserve the anterior part of the lower jaw, Ancylotherium pentelicum shows the greatest amount of incisor reduction. BSPG AS II 147, a pair of lower jaws from Pikermi (Greece) that preserves the symphysis, shows a trace of one very small left incisor tooth (Coombs 1978a). Although there might have been more incisors than are clearly shown in this specimen, they would necessarily have been tiny. The identification of a lower canine alveolus in a specimen of Ancylotherium from Titov Veles (Macedonia) by Garevski and Zapfe (1983) is of some interest. Garevski and Zapfe interpreted this animal as a male, and BSPG AS II 147, which lacks any canine alveolus, as a female. So far, no other specimen of a schizotheriine chalicothere is known to retain a lower canine. I have not seen the Titov Veles specimen that Garevski and Zapfe described and therefore cannot comment directly on the nature of the opening shown in their plate 4 (but see comments on mental foramina on the mandible below).

The immature mandible from St.-Gérand-le-Puy (France) figured by Coombs (1974) and referred to Moropus sp. includes incisor alveoli and dp2-dp4. The first and third alveoli of this specimen are very small, but the second is larger. It is not clear whether the teeth originally in these alveoli were permanent or deciduous, more likely the latter 

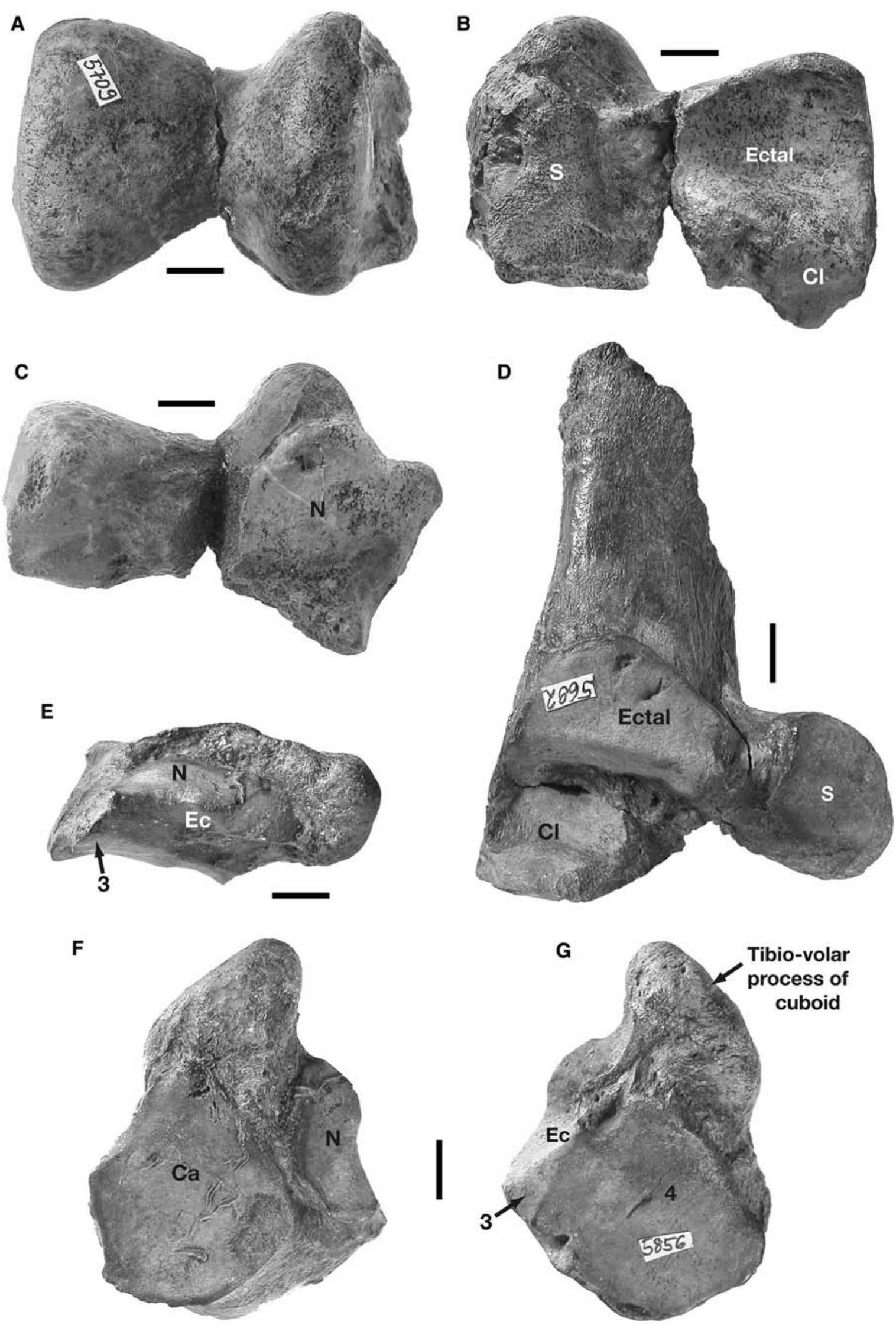


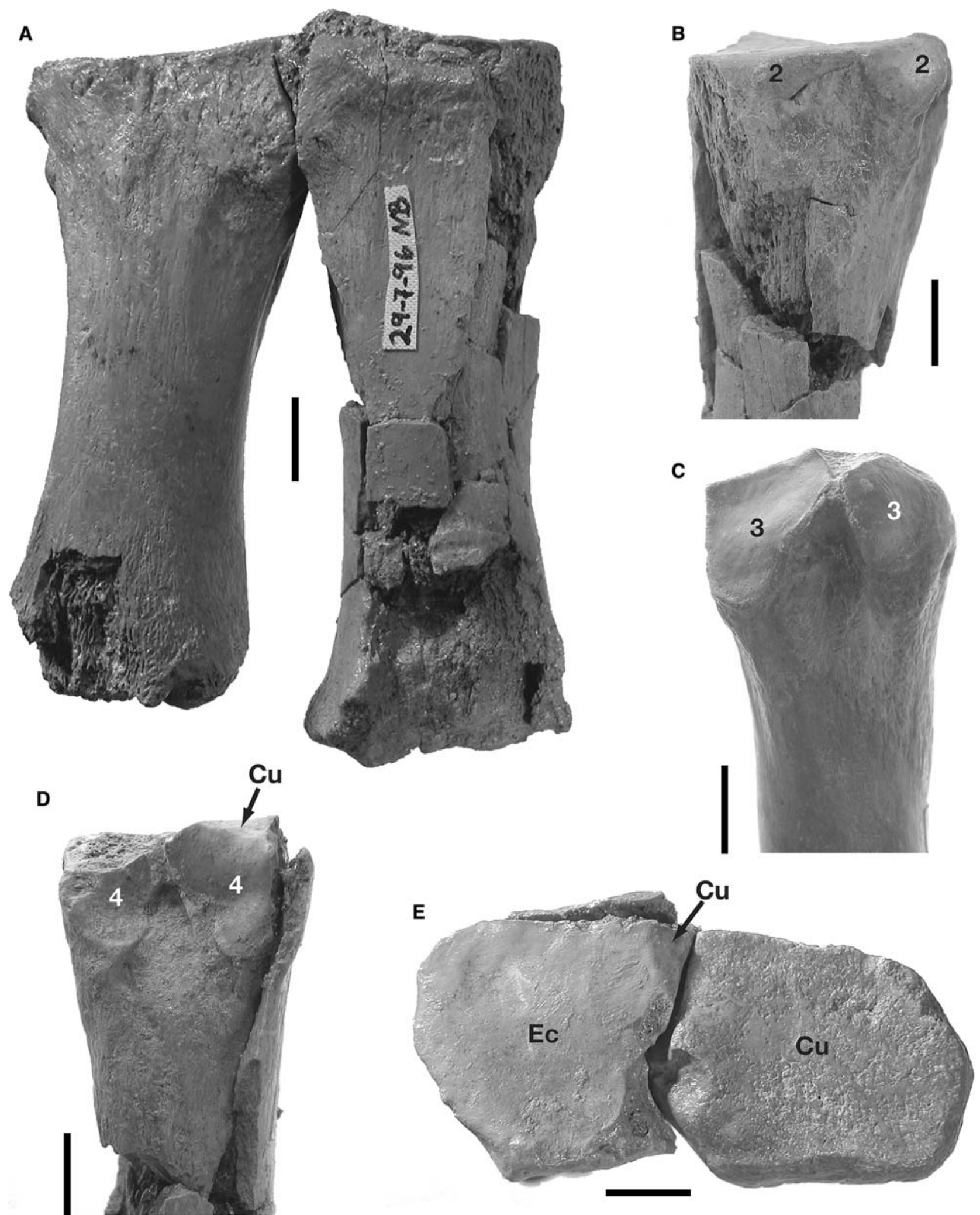

Fig. 11 Metatarsals of $M$. bavaricum from Sandelzhausen: right Mt III (BSPG 1959 II 11555) and right Mt IV (BSPG 1959 II 11558), probably the same individual. a Dorsal view of articulated Mt IIIMt IV, b Tibial view (dorsal at left) of Mt III, c Tibial view (dorsal at left) of Mt IV, d Fibular view (dorsal at right) of Mt III, e Proximal view (dorsal at top) of articulated Mt III-Mt IV. Cu cuboid, Ec ectocuneiform, 2 Mt II, 3 Mt III, 4 Mt IV. Bars $1 \mathrm{~cm}$ 
considering the slight degree of wear on dp2-dp4. It is therefore unclear how big the incisors were in the adult. The metastylid on dp3 and dp4 is separate and almost the same height as the metaconid, and the talonid is wider than the trigonid. Though dp3 is broken it appears to be broadly similar to 292, an isolated dp3 from Sandelzhausen. Unfortunately, no Sandelzhausen specimen preserves dp2, which is unusual in the St.-Gérand specimen in being relatively long and having an unusually strong, discrete paraconid.

The lower premolars and molars of the Sandelzhausen chalicothere can be readily compared with their counterparts in M. wetzleri (BSPG 1867 XII 5: p3-m3; BSPG 1867 XII 6: p4-m1; BSPG 1881 IX 37a: dp3-m1). M. wetzleri has similar $\mathrm{p} 3$ and $\mathrm{p} 4$, but these teeth are closer to the less molariform morphology of the Sandelzhausen chalicothere and are proportionally a little wider and have little metastylid development. Lower molars of $M$. wetzleri have a clearly developed metastylid, but the metastylid is lower than the metaconid. The $\mathrm{m} 3$ is as large as or larger than $\mathrm{m} 2$. In BSPG 1867 XII 5 the trigonids and talonids of $\mathrm{m} 2$ and $\mathrm{m} 3$ are close to the same width, while the $\mathrm{m} 1$ of BSPG 1881 IX 37a has a distinctly wider talonid, as in the Sandelzhausen chalicothere. Lower cheek teeth of M. wetzleri can thus be distinguished from those of the Sandelzhausen form, although they are similar in many ways.

A partial sequence of cheek teeth from Voitsberg (Austria), LMJ 1507, has well-developed metastylids, talonids wider than the trigonids, and straight lophids that meet at a sharp V; this and another lower dental sequence from Voitsberg resemble the Sandelzhausen lower teeth in many ways but are smaller (unlike Voitsberg upper molar material, which is about the same size).

The three lower molars from Steinheim figured by von Koenigswald (1932) as M. fraasi are very similar to those of the Sandelzhausen chalicothere but very slightly larger. Lower teeth of the La Grive schizotheriine figured by Viret (1961) as M. fraasi are quite similar to those of the Sandelzhausen chalicothere and show a comparable degree of molarization of $\mathrm{p} 4$; they are, however, distinctly larger (Table 2). As in the Sandelzhausen material, the talonid is always wider than the trigonid in Steinheim $M$. fraasi and the La Grive schizotheriine.

Cheek teeth of A. pentelicum (BSPG AS II 147) also show some informative similarities to the Sandelzhausen chalicothere. The p2 of BSPG AS II 147 is longer but has a similar lophid connecting the three main cuspids (the unworn paraconid is the tallest cusp in this specimen). BSPG AS II 147 shows an extreme extension of the more molariform development of $\mathrm{p} 3$ and $\mathrm{p} 4$ that is seen in many Sandelzhausen specimens.

Moropus elatus and M. merriami show generally similar morphology of the lower cheek teeth to the Sandelzhausen chalicothere; for example, these chalicotheres have a strong metastylid on the lower molars, and the lophids are straight (M. merriami) or straight to slightly curved (M. elatus). However, in Moropus, $\mathrm{m} 3$ is longer than $\mathrm{m} 2$, and the trigonid and talonid are closer to the same width on $\mathrm{m} 2$ and $\mathrm{m} 3$, though the talonid is usually wider. Lower premolars, especially $\mathrm{p} 2$ and $\mathrm{p} 3$, are less molarized than their counterparts in the Sandelzhausen chalicothere.

The known lower cheek teeth of Phyllotillon naricus resemble those of Moropus in having $\mathrm{m} 3$ longer than $\mathrm{m} 2$ and the trigonid at least as wide as the talonid on these teeth (BMNH M12165). P. naricus has a well-developed metastylid and relatively straight lophids on the lower molars.

Lower molars of Tylocephalonyx have more curved lophids and a weaker metastylid than their counterparts in the Sandelzhausen chalicothere. As in Moropus, m3 is longer than $\mathrm{m} 2$ in Tylocephalonyx, and the trigonid and talonid are closer to the same width on these teeth. Tylocephalonyx reduces the length of the lower premolar row more than any other schizotheriine chalicothere, and this reduction is especially seen in the relatively simple morphology of p2 and p3. Shortening of the talonid of p2 of Tylocephalonyx is greater than in M. elatus or M. merriami (Coombs 1979, 2004).

Coombs (1979, 18, Table 3) and Xue and Coombs (1985, 339, Table 2) summarized the p2-p4 to $\mathrm{m} 1-\mathrm{m} 3$ length ratios in a variety of schizotheriine and chalicotheriine chalicotheres. In primitive members of both subfamilies the premolar row is approximately half the length of the molar row (ratios of approximately 53-54\%). In the Chalicotheriinae, these ratios continually decrease, eventually reaching a low of about $36 \%$ in some species. The Schizotheriinae, which tend to increase the length of the cheek teeth generally, still maintain a ratio of lower premolar to molar lengths of around 50\% (46-56\% in Moropus elatus and $51 \%$ in the one measurable specimen of M. merriami). This ratio can only be measured with reasonable certainty for two specimens of the Sandelzhausen chalicothere: $2509=48 \%$ and $11606=51 \%$. No. 2508 (right side of 2509) has a much higher ratio ( $\sim 61 \%$ ) but is hard to measure because $\mathrm{m} 3$ is not fully erupted; nonetheless, the premolars on this side of the specimen are indeed relatively long. The strongly worn lower cheek teeth of BSPG AS II 147 (Ancylotherium pentelicum) yield a premolar/molar length ratio of approximately $50 \%$ and that of the Titov Veles specimen of A. pentelicum $48 \%$ (Garevski and Zapfe 1983). In general, the Sandelzhausen chalicothere has a premolar/molar length ratio reasonably close to that of most other schizotheriine chalicotheres. In contrast, the shortened premolars of Tylocephalonyx yield a lower premolar/molar length ratio of $41-47 \%$. 


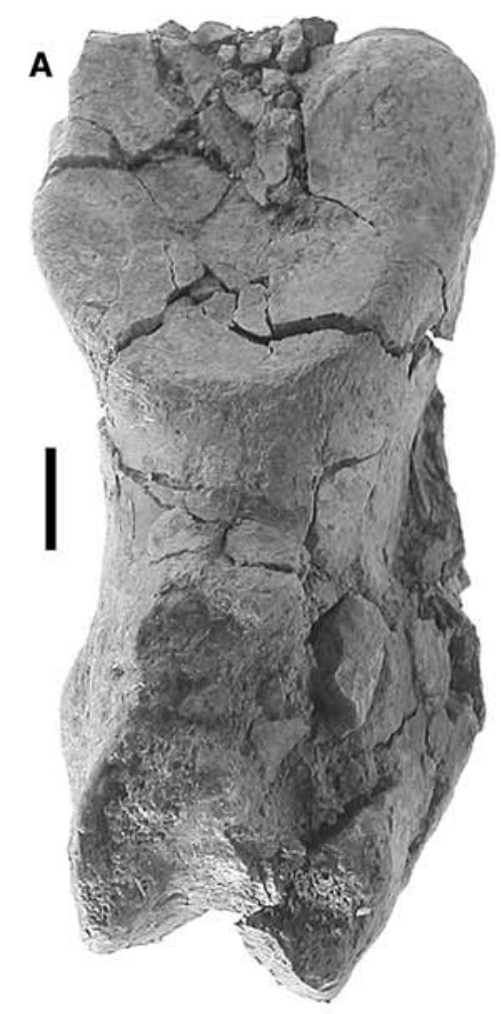

B

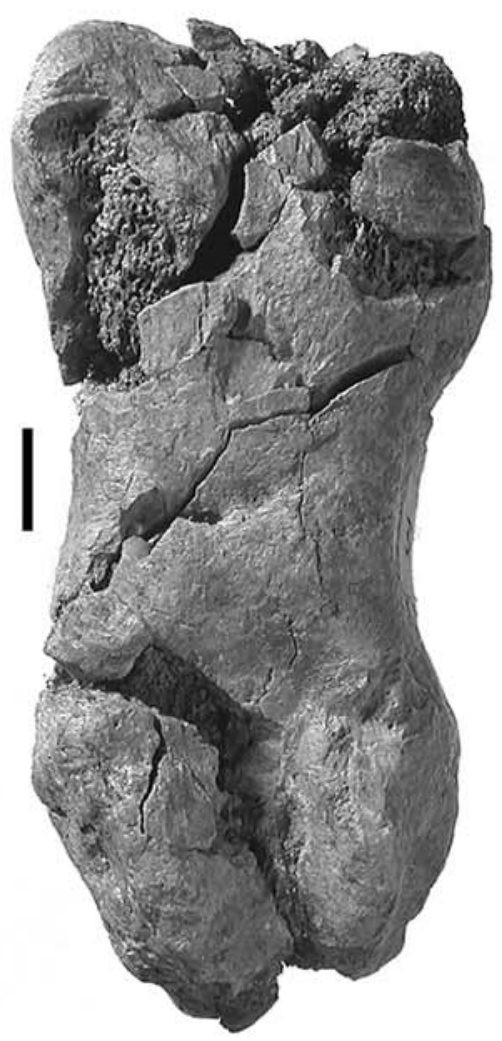

D

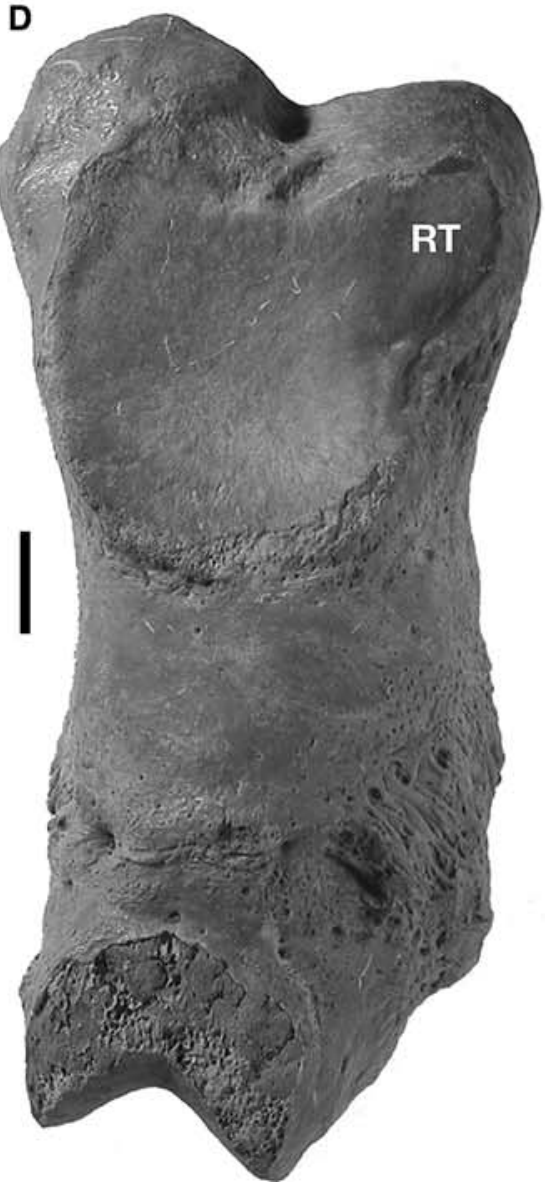

E

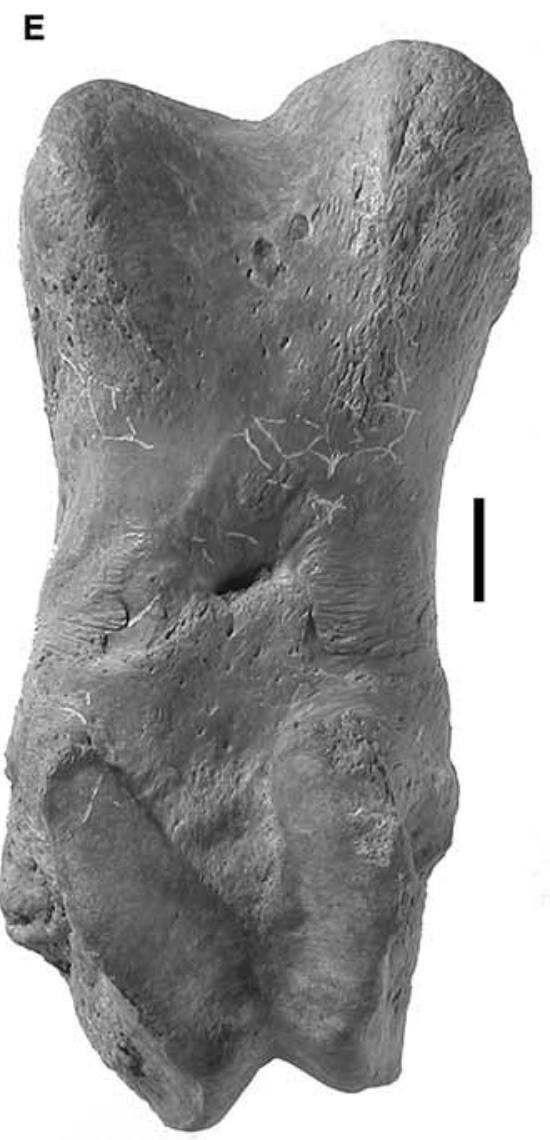

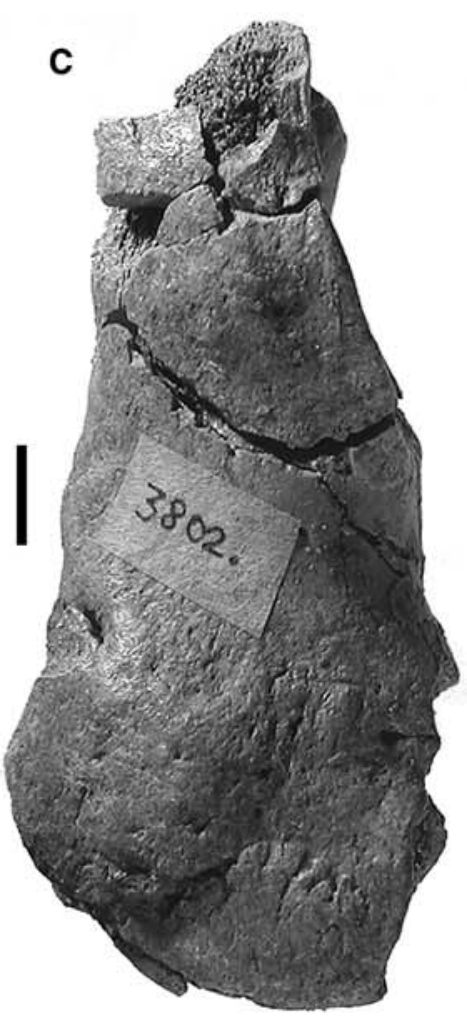

F

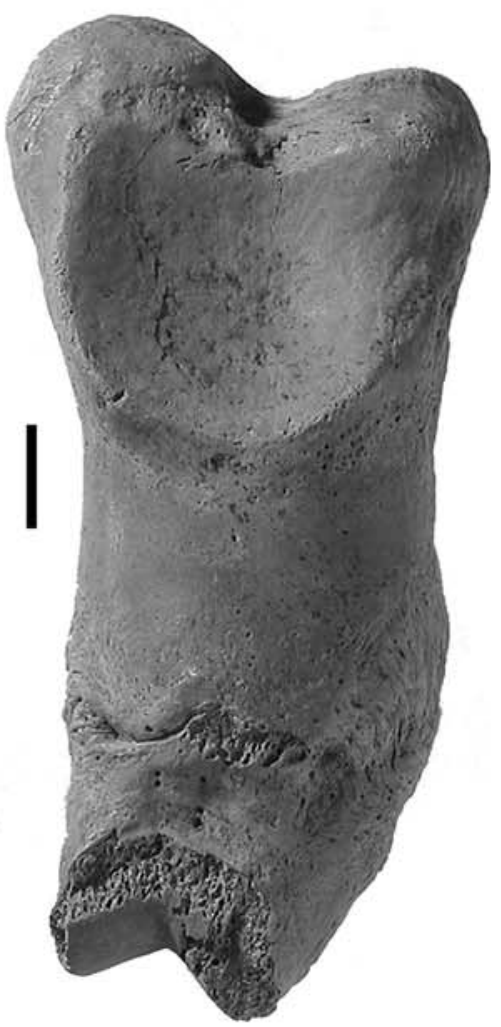


4 Fig. 12 Right duplexes of digit II of the manus of Metaschizotherium. a-c M. bavaricum from Sandelzhausen, BSPG 1959 II 11561. d-e Metaschizotherium from Buchdorf, BSPG 1961 I 485b. f Metaschizotherium from Thannhausen, BSPG 1974 I 24. a, d, and $\mathbf{f}$ are dorsal views, $\mathbf{b}$ and $\mathbf{e}$ volar views, and $\mathbf{c}$ a side view. Bars $1 \mathrm{~cm}$

Mandible

Mandibles in schizotheriine chalicotheres are more slender and less robust than those of chalicotheriines, and the Sandelzhausen chalicothere fits well within schizotheriine morphology. In having a short symphysis that ends well anterior to p2, the Sandelzhausen chalicothere differs from Moropus elatus, Phyllotillon naricus, and Tylocephalonyx skinneri, whose symphysis ends opposite $\mathrm{p} 2$ and Ancylotherium pentelicum, whose symphysis extends opposite $\mathrm{p} 3$ (in BSPG AS II 147). On the other hand, Moropus sp. from St.-Gérand-le-Puy (France), Moropus cf. oregonensis, and Moropus merriami have a similarly short symphysis ending well anterior to the cheek teeth (Coombs 1974, 2004; Coombs et al. 2001). The symphysis in lower jaws of Metaschizotherium wetzleri (BSPG 1881 IX 37a and BSPG 1867 XII 5) is not preserved, but it apparently ended anterior to $\mathrm{dp} 2$ and $\mathrm{p} 2$. Unfortunately none of the Sandelzhausen specimens preserves the full diastema between the incisors and $\mathrm{p} 2$. The diastema appears to be somewhat shorter than the length of the premolar row, as in Moropus merriami and Ancylotherium pentelicum. Phyllotillon naricus (BMNH M12164), Moropus sp. from St.-Gérandle-Puy (Coombs 1974) and Moropus cf. oregonensis (Coombs et al. 2001) have even a shorter diastema, while

\section{A}

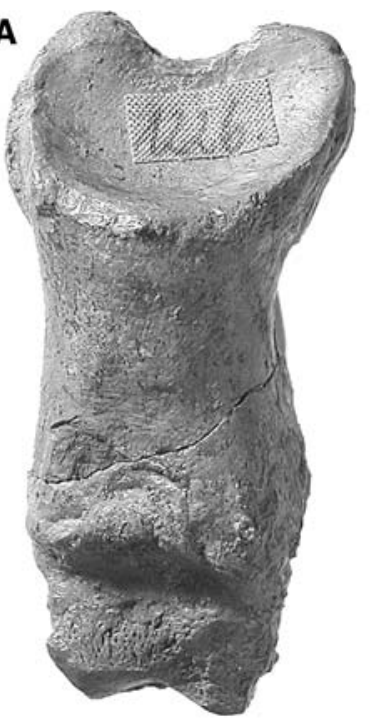

B

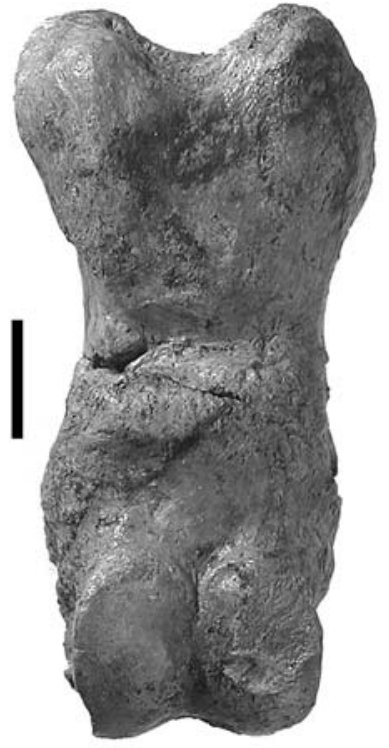

C

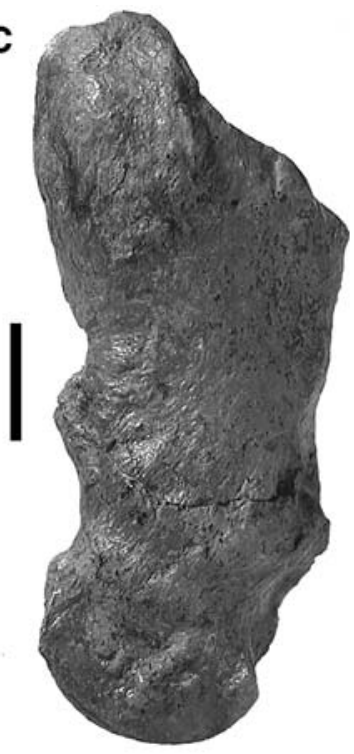

$\mathbf{F}$

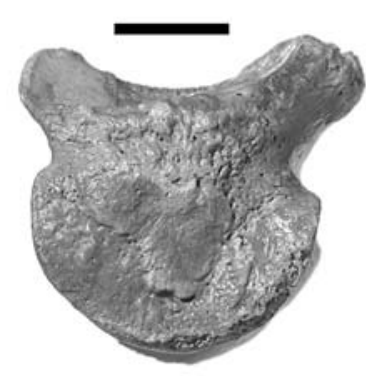

G

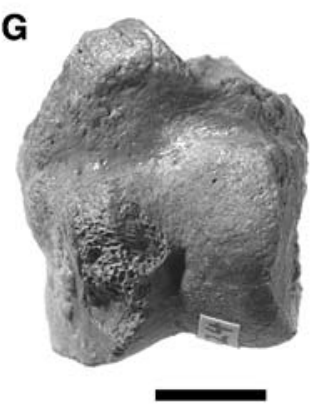

E

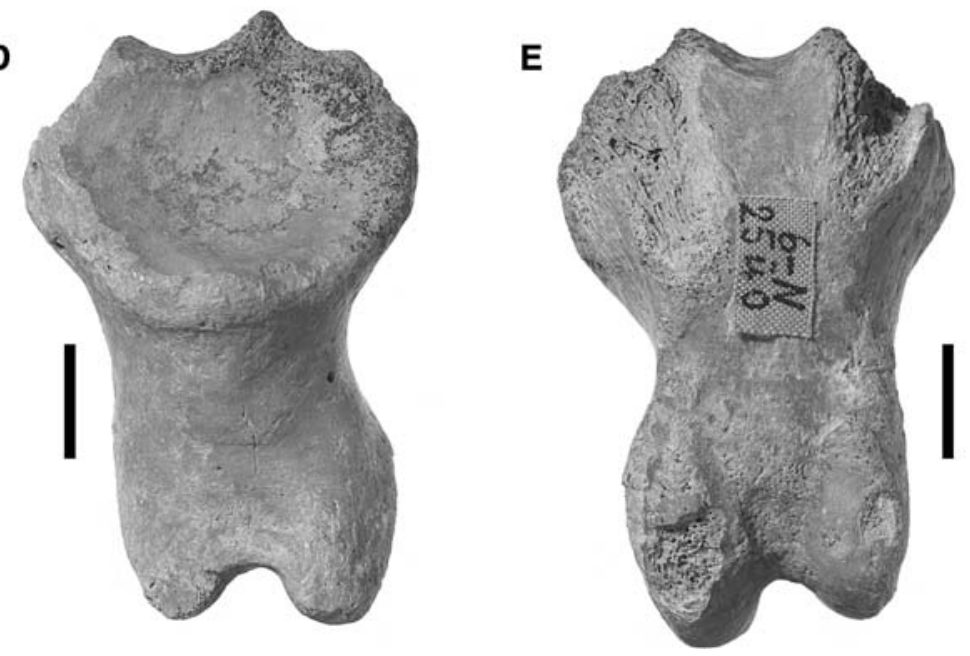

BSPG 1959 II 11608, a proximal phalanx. f Side, $\mathbf{g}$ dorsal, and $\mathbf{h}$ volar views of BSPG 1959 II 11609, a middle phalanx. Bars $1 \mathrm{~cm}$

Fig. 13 Proximal and middle phalanges of M. bavaricum from Sandelzhausen. a Dorsal, b volar, and c side views of BSPG 1959 II 11562, a duplex of digit II of the pes. $\mathbf{d}$ Dorsal and e volar views of 


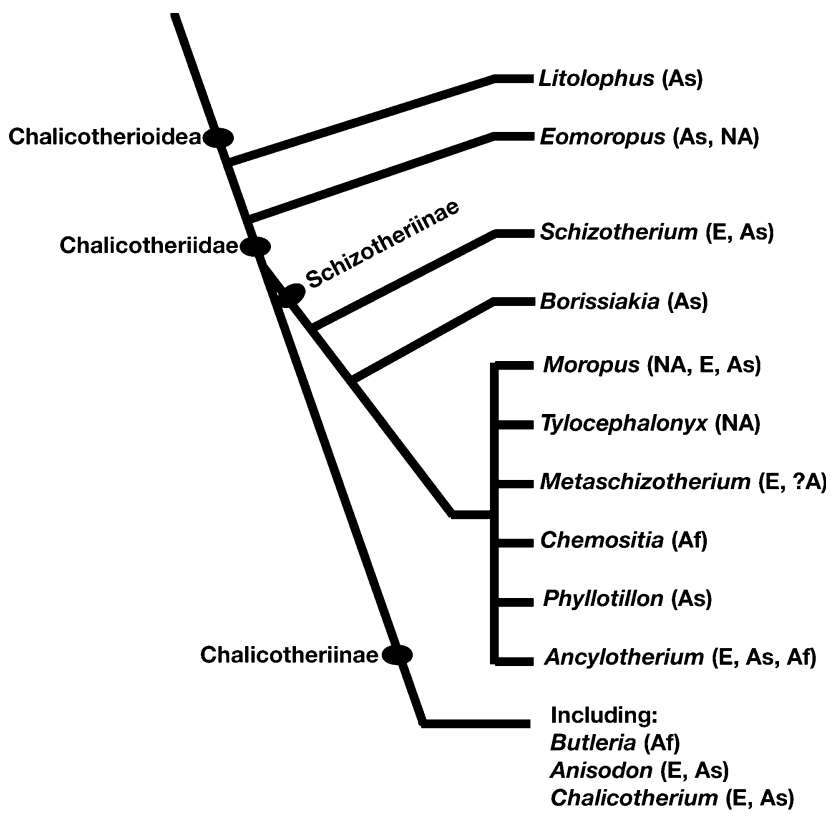

Fig. 14 Schematic cladogram of relationships among selected Chalicotherioidea for reference to taxa discussed in the text. All Schizotheriinae except Schizotherium and Borissiakia are linked by having fused proximal and middle phalanges of digit II of the manus to form a duplex, but relationships among these taxa are still under study

Moropus elatus and Tylocephalonyx skinneri have a diastema that is longer than the premolar row.

Mental foramina on chalicothere lower jaws can be somewhat variable. Individuals of several taxa resemble 11607 from Sandelzhausen in showing a foramen at the anterior end of the mandible just below the incisor area; these include Phyllotillon naricus (BMNH M12164), Moropus sp. from St.-Gérand-le-Puy (Coombs 1974), and Moropus merriami (Coombs 2004). It is possible that the "canine alveolus" cited in the lower jaw of Ancylotherium pentelicum from Titov Veles by Garevski and Zapfe (1983) actually represents such a foramen; the mental foramen in the Pikermi lower jaws of A. pentelicum (BSPG AS II 147) is farther back, almost below p2. The specimen of Moropus elatus illustrated by Holland and Peterson (1914, Fig. 16) shows two mental foramina that are low on the symphysis, well removed from all teeth, and closer to p2 than to i3. The well-developed angle on the lower jaw of 11604 is difficult to compare, because this delicate part of the mandible is often broken off. This part of the jaw is known in Moropus elatus and Tylocephalonyx skinneri, but the angle is flatly continuous with the lower margin of the mandible. The only known sufficiently complete specimen that also shows expansion of the angle is F:AM 54889 from Observation Quarry (early Barstovian of Nebraska, USA; see Coombs 2004, 202-203). The exact affinities of the Observation Quarry chalicothere are troublesome, for a robust femur and humerus from the same deposits differ from those of other known North American chalicotheres, and from the Sandelzhausen chalicothere.

\section{Forelimb}

The proximal end of the humerus is often missing in schizotheriine chalicotheres, as in the Sandelzhausen material. Where it is preserved in specimens of Moropus, Tylocephalonyx, and Ancylotherium, the proximal end is broad with a large deltoid crest and greater tuberosity. The enlargement of this region (in contrast to the Chalicotheriinae; see Zapfe 1979) may partly explain why this part of the humerus so often breaks off. The humerus of M. elatus shows some anterior flexion of the distal articulation compared with the distal shaft (see Holland and Peterson 1914, pl. 66), but slightly less than that in the Sandelzhausen chalicothere. The large entepicondyle of the Sandelzhausen chalicothere is similar to that in other schizotheriine chalicotheres, but the strong ectepicondyle and ectocondylar ridge are larger than those in M. elatus and more comparable to those in Tylocephalonyx and Ancylotherium (Schaub 1943; Coombs 1979). The humerus from Observation Quarry (FAM 54891, Nebraska, USA; see comments under "Mandible" above) also enlarges the ectepicondyle and ectocondylar crest, but differs from the Sandelzhausen chalicothere and Ancylotherium in the shape of the distal facets. In Ancylotherium the distal articulations are narrower than those of any North American chalicothere, as noted by Schaub (1943; see also Roussiakis and Theodorou 2001, 567, Fig. 23). In contrast, the trochlea of the Sandelzhausen chalicothere is narrow, but the capitulum is broad. The distal articular facets have the further unusual feature, not seen in Ancylotherium or North American schizotheriines, of being displaced laterally toward the ectepicondyle to such a degree that the capitulum is lateral to the axis of the humeral shaft.

The ulna and radius of the Sandelzhausen chalicothere resemble counterparts in Moropus and Tylocephalonyx in general proportions, facet shapes, and size and shape of the olecranon and anconeal processes. In contrast, the radius and ulna of Ancylotherium are proportionately shorter and more broadened distally (Schaub 1943; Roussiakis and Theodorou 2001). The shaft of the radius of Ancylotherium also displays considerable torsion, while that of the Sandelzhausen chalicothere and of Tylocephalonyx and Moropus shows only slight torsion. Known specimens of Ancylotherium display strong fusion between the radius and ulna, most obvious at the distal end (Schaub 1943; Roussiakis and Theodorou 2001). Moropus and Tylocephalonyx are more variable in the degree of distal fusion, most likely related to the age of the animal (Coombs 1978b; 1979). The lack of distal fusion in the Sandelzhausen material most likely reflects a relatively young age 
Table 3 Ages of selected European Schizotheriinae compared with Metaschizotherium bavaricum in the text

\begin{tabular}{|c|c|c|}
\hline MN zones/age & Localities (country) & Probable taxon \\
\hline $\begin{array}{l}\text { MN11-13 } \\
\text { Turolian } \\
8.7-4.9 \mathrm{Ma}\end{array}$ & $\begin{array}{l}\text { Samos (Greece) } \\
\text { Pikermi (Greece) } \\
\text { Halmyropotamos (Greece) } \\
\text { Titov Veles (Macedonia) } \\
\text { Kalimantsi (Bulgaria) } \\
\text { Gorna Sushitsa (Bulgaria) } \\
\text { Hadjidimovo (Bulgaria) }\end{array}$ & $\begin{array}{l}\text { Ancylotherium pentelicum } \\
\text { (all Turolian material) }\end{array}$ \\
\hline $\begin{array}{l}\text { MN9-10 } \\
\text { Vallesian } \\
11.1-8.7 \mathrm{Ma}\end{array}$ & $\begin{array}{l}\text { Valles de Fuentidueña (Spain) } \\
\text { Krems (Austria) } \\
\text { (both MN9) }\end{array}$ & $\begin{array}{l}\text { Ancylotherium sp. } \\
\text { Ancylotherium or Metaschizotherium }\end{array}$ \\
\hline $\begin{array}{l}\text { MN7-8 } \\
\text { Late Astaracian } \\
13.5-11.1 \mathrm{Ma}\end{array}$ & $\begin{array}{l}\text { La Grive (France)_MN7-8 } \\
\text { Kaisersteinbruch (Austria) } \\
\text { Steinheim (Germany)—MN7 }\end{array}$ & $\begin{array}{l}\text { Uncertain } \\
\text { Metaschizotherium cf. fraasi } \\
\text { Metaschizotherium fraasi }\end{array}$ \\
\hline $\begin{array}{l}\text { MN6 } \\
\text { Early Astaracian } \\
15.0-13.5 \mathrm{Ma}\end{array}$ & $\begin{array}{l}\text { Buchdorf (Germany)_age? } \\
\text { Petersbuch } 71 \text { (Germany) } \\
\text { Thannhausen (Germany) } \\
\text { Stätzling (Germany) }\end{array}$ & $\begin{array}{l}\text { Metaschizotherium } \\
\text { Metaschizotherium cf. fraasi } \\
\text { Metaschizotherium } \\
\text { Metaschizotherium bavaricum }\end{array}$ \\
\hline $\begin{array}{l}\text { MN5 } \\
\text { Late Orleanian } \\
17.0-15.0 \mathrm{Ma}\end{array}$ & $\begin{array}{l}\text { Häder (Germany) } \\
\text { Faluns d'Anjou (France) } \\
\text { Viehhausen (Germany) } \\
\text { Sandelzhausen (Germany) } \\
\text { Voitsberg (Austria; MN4-5) }\end{array}$ & $\begin{array}{l}\text { Metaschizotherium bavaricum } \\
\text { Uncertain } \\
\text { Metaschizotherium bavaricum } \\
\text { Metaschizotherium bavaricum } \\
\text { Metaschizotherium cf. bavaricum }\end{array}$ \\
\hline $\begin{array}{l}\text { MN4 } \\
18.0-17.0 \mathrm{Ma}\end{array}$ & $\begin{array}{l}\text { Charneca do Lumiar (Portugal) } \\
\text { Buñol (Spain) }\end{array}$ & $\begin{array}{l}\text { Moropus sp. } \\
\text { Moropus sp. }\end{array}$ \\
\hline MN3 & Alto de Ballester I (Spain) & Moropus sp. \\
\hline Early Orleanian & Michelsberg bei Ulm (Germany) & Metaschizotherium? wetzleri \\
\hline $20.5-18.0 \mathrm{Ma}$ & Tuchorice (Czech Republic) & Metaschizotherium? cf. wetzleri \\
\hline MN2 & Eggingen (Germany) & Metaschizotherium? wetzleri \\
\hline Agenian & St.-Gérand-le-Puy (France) & Moropus sp. \\
\hline $22.5-20.5 \mathrm{Ma}$ & Montaigu-le-Blin (France) & Moropus sp. \\
\hline
\end{tabular}

of these animals at death. In any case, none of these chalicotheres could rotate the forearm, though the shape of the facets for the proximal carpals suggests good flexion and side-to-side movement at the wrist.

Because none of the Sandelzhausen forelimb long bones is preserved in its full length, it is not possible to calculate important proportions of these bones. Nonetheless, the morphology of the available material suggests that the proportions of the humerus, radius, and ulna were relatively gracile and closer to those of Moropus and Tylocephalonyx than to their more shortened, robust counterparts in Ancylotherium.

Carpals of the Sandelzhausen chalicothere generally resemble their counterparts in Moropus and
Tylocephalonyx much more than they do the specialized carpals of Ancylotherium, which have been described and figured by Schaub (1943), Butler (1965), Roussiakis and Theodorou (2001), and Saraç et al. (2002). The wrist of Ancylotherium is strongly modified for flexion between the proximal and distal rows of carpals. There is thus no independent trapezium, the distal process on the scaphoid and the volar process of the lunate are strongly reduced, and there are extensive proximo-volar flexor articulations on the trapezoid, magnum, and unciform. The distal row of carpals protrudes dorsally beyond the proximal row (see Schaub 1943, 10, Fig. 5A, and pl. 2), but volar projections, such as the disto-volar hook on the magnum and ulno-volar process on the unciform, are very reduced. Ancylotherium 
Table 4 Dental comparisons of the Sandelzhausen chalicothere to other Schizotheriinae

\begin{tabular}{|c|c|c|c|c|c|c|c|}
\hline $\begin{array}{l}\text { M. bavaricum } \\
\text { Sandelzhausen }\end{array}$ & $\begin{array}{l}\text { M. fraasi } \\
\text { Steinheim }\end{array}$ & $\begin{array}{l}\text { M. bavaricum } \\
\text { Hader }\end{array}$ & $\begin{array}{l}\text { La Grive } \\
\text { schizotheriine } \\
\text { La Grive }\end{array}$ & $\begin{array}{l}\text { Phyllotillon } \\
\text { naricus } \\
\text { Bugti }\end{array}$ & Various sites, USA & $\begin{array}{l}\text { Sheep Creek } \\
\text { (Nebraska, } \\
\text { USA) }\end{array}$ & $\begin{array}{l}\text { Ancylotherium } \\
\text { Greece, } \\
\text { Macedonia, } \\
\text { Bulgaria }\end{array}$ \\
\hline $\begin{array}{l}\text { P4: small } \\
\text { hypocone, } \\
\text { large } \\
\text { cingula }\end{array}$ & $\begin{array}{l}\text { Only P3 } \\
\text { known }\end{array}$ & $\begin{array}{l}\text { P4: small } \\
\text { hypocone, } \\
\text { large } \\
\text { cingula }\end{array}$ & $\begin{array}{l}\mathrm{P} 4 \text { protocone } \\
\text { ridge-like, } \\
\text { large } \\
\text { cingula }\end{array}$ & $\begin{array}{l}\text { P4 protocone } \\
\text { pointed, } \\
\text { large } \\
\text { lingual } \\
\text { cingula }\end{array}$ & $\begin{array}{l}\text { P4 protocone cusplike } \\
\text { or crescentic, medium } \\
\text { to strong cingula }\end{array}$ & $\begin{array}{l}\text { P4 protocone } \\
\text { crescentic, } \\
\text { strong } \\
\text { lingual } \\
\text { cingula }\end{array}$ & $\begin{array}{l}\text { P3 and P4 larger with } \\
\text { crochet; protocone } \\
\text { crescentic, often } \\
\text { with } 2 \text { nd cusp; } \\
\text { medium-strong } \\
\text { ant-lingual cingula }\end{array}$ \\
\hline $\begin{array}{r}\text { No molar } \\
\text { crochet }\end{array}$ & $\begin{array}{r}\text { No molar } \\
\text { crochet }\end{array}$ & $\begin{array}{l}\text { No molar } \\
\text { crochet }\end{array}$ & $\begin{array}{l}\text { Crochet } \\
\text { present }\end{array}$ & $\begin{array}{l}\text { Occasional } \\
\text { weak } \\
\text { crochet }\end{array}$ & No molar crochet & $\begin{array}{r}\text { No molar } \\
\text { crochet }\end{array}$ & $\begin{array}{l}\text { Crochet } \\
\text { present }\end{array}$ \\
\hline $\begin{array}{l}\text { Molars not } \\
\text { high- } \\
\text { crowned }\end{array}$ & $\begin{array}{l}\text { Molars not } \\
\text { high- } \\
\text { crowned }\end{array}$ & $\begin{array}{l}\text { Molars not } \\
\text { high- } \\
\text { crowned }\end{array}$ & $\begin{array}{l}\text { Molars more } \\
\text { high- } \\
\text { crowned }\end{array}$ & $\begin{array}{l}\text { Molars } \\
\text { medium } \\
\text { crowned }\end{array}$ & $\begin{array}{l}\text { Variable crown } \\
\text { heights }\end{array}$ & $\begin{array}{l}\text { Molars } \\
\text { medium } \\
\text { crowned }\end{array}$ & $\begin{array}{l}\text { Molars more high- } \\
\text { crowned }\end{array}$ \\
\hline $\begin{array}{l}\text { M3 metaloph } \\
\text { not close to } \\
\text { mesostyle }\end{array}$ & $\begin{array}{l}\text { M3 } \\
\text { metaloph } \\
\text { not close } \\
\text { to } \\
\text { mesostyle }\end{array}$ & $\begin{array}{l}\text { M3 metaloph } \\
\text { not close to } \\
\text { mesostyle }\end{array}$ & $\begin{array}{l}\text { M3 metaloph } \\
\text { not close to } \\
\text { mesostyle }\end{array}$ & $\begin{array}{l}\text { M3 metaloph } \\
\text { may } \\
\text { originate } \\
\text { close to } \\
\text { mesostyle }\end{array}$ & $\begin{array}{l}\text { M3 metaloph } \\
\text { originates close } \\
\text { to mesostyle in } \\
\text { early species, } \\
\text { but not } \\
\text { in later ones }\end{array}$ & $\begin{array}{l}\text { M3 metaloph } \\
\text { not close to } \\
\text { mesostyle }\end{array}$ & $\begin{array}{l}\text { M3 metaloph } \\
\text { not close } \\
\text { to mesostyle }\end{array}$ \\
\hline $\begin{array}{l}\text { M3 hypocone } \\
\text { strong }\end{array}$ & $\begin{array}{l}\text { M3 } \\
\text { hypocone } \\
\text { weak to } \\
\text { moderate }\end{array}$ & & $\begin{array}{l}\text { M3 hypocone } \\
\text { moderate }\end{array}$ & $\begin{array}{l}\text { M3 hypocone } \\
\text { strong }\end{array}$ & $\begin{array}{l}\text { M3 hypocone } \\
\text { moderate to } \\
\text { strong }\end{array}$ & $\begin{array}{l}\text { M3 hypocone } \\
\text { weak }\end{array}$ & $\begin{array}{l}\text { M3 hypocone } \\
\text { weak }\end{array}$ \\
\hline $\begin{array}{l}\text { 2-3 small } \\
\text { lower } \\
\text { incisors, } \\
\text { one tiny }\end{array}$ & $?$ & $?$ & $?$ & $\begin{array}{l}3 \text { good-sized } \\
\text { alveoli }\end{array}$ & $\begin{array}{l}3 \text { good-sized in } \\
\text { M. elatus; smaller } \\
\text { alveoli in } \\
\text { M. merriami }\end{array}$ & $\begin{array}{l}3 \text { incisors, i3 } \\
\text { reduced }\end{array}$ & $\begin{array}{l}\text { One very small, } \\
\text { ?others }\end{array}$ \\
\hline $\begin{array}{l}\text { p2 and p3 } \\
\text { slightly } \\
\text { molariform }\end{array}$ & $?$ & $?$ & $\begin{array}{l}\text { p2 and p3 } \\
\text { slightly } \\
\text { molariform }\end{array}$ & & $\begin{array}{l}\mathrm{p} 2 \text { and } \mathrm{p} 3 \text { less } \\
\text { molariform }\end{array}$ & $\begin{array}{l}\mathrm{p} 2 \text { and } \mathrm{p} 3 \\
\text { reduced and } \\
\text { shortened }\end{array}$ & $\begin{array}{l}\mathrm{p} 2 \text { and } \mathrm{p} 3 \text { more } \\
\text { molariform }\end{array}$ \\
\hline $\mathrm{m} 2>\mathrm{m} 3$ & & & & $\mathrm{~m} 2<\mathrm{m} 3$ & $\mathrm{~m} 2<\mathrm{m} 3$ & $\mathrm{~m} 2<\mathrm{m} 3$ & $\mathrm{~m} 2<\mathrm{m} 3$ \\
\hline
\end{tabular}

also has modified its proximal carpals to allow more sideto-side excursion of the wrist against the radius/ulna complex. Both the scaphoid and cuneiform taper away from the lunate, forming a transverse arch (see Schaub 1943, 11, Fig. 8).

Table 5 compares carpals and metacarpals of the Sandelzhausen chalicothere with those of other Miocene schizotheriine chalicotheres. In general, the carpus of the Sandelzhausen chalicothere resembles that of its closer contemporaries Tylocephalonyx skinneri and Moropus merriami more than that of the earlier species Moropus elatus; for example, M. merriami and T. skinneri have a smaller and less squared distal process on the scaphoid and a less cupped volar process on the lunate than does M. elatus (Coombs 1978b, 1979, 2004). The carpus of Moropus hollandi resembles that of M. elatus in most respects, except for its (presumably independent) loss of the trapezium (Coombs 1978b).
A few isolated schizotheriine carpals have been described from various European localities that are close to contemporaneous with Sandelzhausen. The most important of these is the lunate described as Metaschizotherium fraasi by Rinnert (1956) from Viehhausen (Oberpfalz Brown Coal), Germany. Rinnert figured a dorsal view of this bone and noted that it resembled the lunate of "Colodus pentelicus" (i.e., Ancylotherium pentelicum) in having the unciform facet extend onto the dorsal surface of the bone. This character is probably not significant, because the unciform facet curves onto the dorsal surface of the lunate in Moropus and Tylocephalonyx (and in the Sandelzhausen chalicothere). Ancylotherium is unusual in having the magnum facet also extend onto the dorsal surface of the lunate (Schaub 1943); this character does not occur in Moropus, Tylocephalonyx or the Sandelzhausen and Viehhausen lunates. In 1972 I examined the Viehhausen lunate (BSPG/IPW no. 93). Its volar surface was damaged, 
Table 5 Comparison of carpals and metacarpals of selected Schizotheriinae

\begin{tabular}{|c|c|c|c|c|c|c|}
\hline Character & $\begin{array}{l}\text { M. bavaricum } \\
\text { Sandelzhausen }\end{array}$ & $\begin{array}{l}\text { Moropus } \\
\text { elatus }\end{array}$ & $\begin{array}{l}\text { Moropus } \\
\text { merriami }\end{array}$ & $\begin{array}{l}\text { Tylocephalonyx } \\
\text { skinneri }\end{array}$ & $\begin{array}{l}\text { Ancylotherium } \\
\text { pentelicum }\end{array}$ & Other \\
\hline Trapezium & Present & Present & Present & Present & Absent or fused & \\
\hline $\begin{array}{l}\text { Scaphoid distal process/ } \\
\text { magnum facet }\end{array}$ & $\begin{array}{l}\text { Reduced/ } \\
\text { oblique }\end{array}$ & $\begin{array}{l}\text { Strong/ } \\
\text { squared }\end{array}$ & $\begin{array}{l}\text { Reduced/ } \\
\text { oblique }\end{array}$ & $\begin{array}{l}\text { Reduced/ } \\
\text { oblique }\end{array}$ & Very reduced/oblique & \\
\hline Volar process of lunate & $\begin{array}{l}\text { Medium, not } \\
\text { cupped }\end{array}$ & $\begin{array}{l}\text { Medium to } \\
\text { strong, } \\
\text { cupped }\end{array}$ & $\begin{array}{l}\text { Medium, not } \\
\text { cupped }\end{array}$ & $\begin{array}{l}\text { Medium, not } \\
\text { cupped } \\
\text { (based on } \\
\text { magnum) }\end{array}$ & Strongly reduced & $\begin{array}{l}\text { Viehhausen: broken } \\
\text { or reduced; } \\
\text { Buñol: medium } \\
\text { (based on } \\
\text { magnum) }\end{array}$ \\
\hline $\begin{array}{l}\text { Disto-volar hook on } \\
\text { magnum }\end{array}$ & Medium-short & Medium & Medium & Medium & Very reduced & $\begin{array}{l}\text { Buñol: medium to } \\
\text { short }\end{array}$ \\
\hline $\begin{array}{l}\text { Facets between scaphoid } \\
\text { and lunate }\end{array}$ & $\begin{array}{l}\text { Large } \\
\text { proximal, } \\
\text { small distal }\end{array}$ & $\begin{array}{l}\text { Large } \\
\text { proximal, } \\
\text { well- } \\
\text { developed } \\
\text { distal }\end{array}$ & $\begin{array}{l}\text { Large } \\
\text { proximal, } \\
\text { small } \\
\text { distal }\end{array}$ & $\begin{array}{l}\text { Large } \\
\text { proximal, } \\
\text { well- } \\
\text { developed } \\
\text { distal }\end{array}$ & $\begin{array}{l}\text { Large proximal, well- } \\
\text { developed distal }\end{array}$ & $\begin{array}{l}\text { Viehhausen: large } \\
\text { proximal, very } \\
\text { small distal; } \\
\text { Buñol: large } \\
\text { proximal, well- } \\
\text { developed distal }\end{array}$ \\
\hline $\begin{array}{l}\text { Proximal facet between } \\
\text { lunate and cuneiform } \\
\text { (in addition to distal } \\
\text { facet) }\end{array}$ & Yes & No or weak & No & No or weak & No & $\begin{array}{l}\text { Viehhausen: no or } \\
\text { weak; } \\
\text { Buñol: no }\end{array}$ \\
\hline $\begin{array}{l}\text { Unciform ulno-volar } \\
\text { process }\end{array}$ & $\begin{array}{l}\text { Absent or } \\
\text { small }\end{array}$ & Large & Intermediate & Intermediate & Not present & \\
\hline $\begin{array}{l}\text { Magnum facet curves } \\
\text { onto dorsal surface of } \\
\text { lunate }\end{array}$ & $\begin{array}{l}\text { No (ridge } \\
\text { present at } \\
\text { dorsal edge) }\end{array}$ & No & $?$ & No & Yes & $\begin{array}{l}\text { Viehhausen: no } \\
\text { (ridge present at } \\
\text { dorsal edge?); } \\
\text { Buñol: no? }\end{array}$ \\
\hline $\begin{array}{l}\text { Facet between Mc III } \\
\text { and Mc IV }\end{array}$ & $\begin{array}{l}1 \text { long, dorsal } \\
\text { to volar } \\
\text { continuous }\end{array}$ & $\begin{array}{l}1 \text { or } 2 \text { (single } \\
\text { or divided) } \\
\text { long, } \\
\text { dorsal to } \\
\text { volar }\end{array}$ & $\begin{array}{l}1 \text { long, } \\
\text { dorsal } \\
\text { to volar } \\
\text { continuous }\end{array}$ & 1 dorsal only & $\begin{array}{l}1 \text { long, dorsal to volar } \\
\text { continuous }\end{array}$ & \\
\hline Mc V & $\begin{array}{l}\text { Very small } \\
\text { (pit for it on } \\
\text { Mc IV) }\end{array}$ & $\begin{array}{l}\text { Known } \\
\text { small; } \\
\text { clear facet } \\
\text { on Mc IV }\end{array}$ & $\begin{array}{l}\text { Very small } \\
\text { (pit for it } \\
\text { on Mc IV) }\end{array}$ & $\begin{array}{l}\text { Very small (pit } \\
\text { more } \\
\text { proximal } \\
\text { on Mc IV) }\end{array}$ & Lost (no facet on Mc IV) & \\
\hline Metacarpal shafts & Rounded/oval & $\begin{array}{c}\text { Rounded/ } \\
\text { oval }\end{array}$ & $\begin{array}{c}\text { Rounded/ } \\
\text { oval }\end{array}$ & Rounded/oval & $\begin{array}{l}\text { Strongly concave dorsally; } \\
\text { angular with strong crests } \\
\text { and proximal } \\
\text { protuberances }\end{array}$ & \\
\hline
\end{tabular}

but I concluded that the volar process was strongly reduced, a similarity with Ancylotherium. This observation was the basis of my assertion (Coombs 1974, 279) that "Ancylotherium (Metaschizotherium) fraasi" resembles "A. (A.) pentelicum" in having a lunate with a strongly reduced volar process. This statement needs to be revisited in view of the development of the volar process in the two lunate specimens from Sandelzhausen. Either the Viehhausen lunate originally had a better-developed volar process than is now visible, or it is not the same taxon as the Sandelzhausen lunates. As noted above, P3 of the
Viehhausen chalicothere is quite similar to its counterparts from Sandelzhausen.

Belinchon and Montoya (1989-1990) described a lunate, magnum, and pisiform, which they referred to Phyllotillon naricus, from Buñol (Valencia, Spain; MN4). The volar process on the lunate of this animal is broken off, but the structure of the well-developed corresponding articular area on the magnum suggests that it was reasonably well developed. The volar hook on the magnum is comparably developed to that in 11570 from Sandelzhausen, i.e., somewhat shorter than the volar 
Table 6 Mc II proportions of selected chalicotheres

\begin{tabular}{|c|c|c|c|c|}
\hline \multirow{13}{*}{$\begin{array}{l}\text { Table } 6 \text { Mc II proportions of } \\
\text { selected chalicotheres }\end{array}$} & Taxon/specimen & Minimal shaft width & Length & Min. shaft width/length \\
\hline & Metaschizotherium bavaricum & & & \\
\hline & BSPG 1959 II 11639 (Sandelzhausen) & 36.1 & 164.4 & 0.22 \\
\hline & Metaschizotherium & & & \\
\hline & BSPG 1961 I 485a (Buchdorf) & 39.4 & $\sim 176.5$ & $\sim 0.22$ \\
\hline & Moropus elatus & & & \\
\hline & AMNH 14378 (Agate) & 32.0 & 198.0 & 0.16 \\
\hline & Morava Ranch Quarry $(N=5)$ & $35.2-38.1$ & $196.6-215.0$ & $0.17-0.18$ \\
\hline & Tylocephalonyx skinneri & & & \\
\hline & Greenside Quarry $(N=3)$ & $37.4-43.7$ & $190.5-206.4$ & $0.18-0.21$ \\
\hline & Borissiakia betpakdalensis & & & \\
\hline & 3481 from Borissiak 1946 & 30 & 257 & 0.116 \\
\hline & Schizotherium priscum & & & \\
\hline$x_{0}$ & From Filhol 1894 & 10.4 & 77.0 & 0.135 \\
\hline
\end{tabular}

Measurements in mm

hook of North American Moropus and Tylocephalonyx, but not as reduced as in Ancylotherium. Further study is necessary to ascertain whether the material from Buñol might belong to the same taxon as the Sandelzhausen chalicothere.

The most notable difference of the Sandelzhausen pisiform from that of M. elatus and T. skinneri is the relative shortness and greater width of its shaft, giving it a stubbier appearance. It differs in the same way from the pisiform from Buñol figured by Belinchon and Montoya (1989-1990). Schaub (1943) observed that the pisiform of A. pentelicum also was shorter than that of M. elatus, but he noted a very strong broadening of the free end for insertion of the flexor carpi ulnaris muscle in A. pentelicum, a feature that is absent in the Sandelzhausen pisiform.

The bone figured by von Koenigswald (1932, pl. 2, Figs. 24, 25) as a hamate (=unciform) of Metaschizotherium does not seem to belong to a schizotheriine chalicothere and is thus not discussed further here.

Mc II resembles its counterpart in M. elatus and T. skinneri in having a clear articular facet for the trapezium and in having a rounded oval to slightly triangular shaft. In contrast, A. pentelicum lacks a free trapezium, which has either been fused to Mc II (Schaub 1943) or lost, and its Mc II has a flattened, dorsally concave shaft with a strong ridge connecting the medial tuberosity of the distal end with the large dorso-ulnar process at the proximal end. A. pentelicum also differs in having a deep fissure between the dorsal part of the distal articulation and the shaft. Another similarity to M. elatus and T. skinneri is the curved shape of the articulations for the magnum and Mc III; the flatter facets between Mc II and these adjacent bones in Ancylotherium would allow less movement of Mc II against them (Table 6).
I compared the specimens of Mc II from Sandelzhausen with a better-preserved, slightly larger Mc II, BSPG 1961 I 485a, collected from deposits of uncertain age at Buchdorf, $8 \mathrm{~km}$ north-northeast of Donauwörth, Bavaria, Germany (Fig. 8e-g). This specimen also is referable to Metaschizotherium and is quite similar in most respects to the Sandelzhausen material. Together, these Mc II specimens highlight a proportional difference from M. elatus (Table 7): Mc II of Metaschizotherium is proportionately shorter compared with shaft width. Mc II of T. skinneri has intermediate proportions, while sample representatives of the more basal schizotheriines Borissiakia and Schizotherium have a much longer, more slender Mc II.

Mc IV is quite similar to its counterpart in M. elatus and M. merriami (Coombs 2004). All have a large facet for Mc III. In M. elatus this facet varies in being single or double, depending on the degree of separation between the two parts. A small $\mathrm{Mc} \mathrm{V}$ is known for M. elatus and there is a more distinct facet for it on Mc IV. Mc IV of M. merriami has a notch for Mc $\mathrm{V}$ near the proximal end but has no distinct facet, resembling Mc IV from Sandelzhausen in this regard. T. skinneri differs from all the preceding in having a single, dorsal, Mc III facet. The volar part of the Mc III facet present in Moropus and Metaschizotherium is absent (Coombs 1979); instead the volar part of the unciform facet meets the radial edge of Mc IV at a sharp ridge with no bordering facet. The $\mathrm{Mc} \mathrm{V}$ facet in T. skinneri is relatively proximal and may be associated with a notch on the ulno-volar edge of the proximal end. Mc IV of A. pentelicum has a flattened, dorsally concave shaft that differs strongly from the rounded, oval shafts of the other taxa. Enlarged rugosities border the proximal end on the dorsal and ulnar edges (Schaub 1943). There is a larger, bowl-shaped unciform facet and no sign of an 
Table 7 Tarsal and metatarsal characters in selected Schizotheriinae

\begin{tabular}{|c|c|c|c|c|c|c|}
\hline Character & $\begin{array}{l}\text { M. bavaricum } \\
\text { Sandelzhausen }\end{array}$ & $\begin{array}{l}\text { Moropus } \\
\text { elatus }\end{array}$ & $\begin{array}{l}\text { Moropus } \\
\text { merriami }\end{array}$ & $\begin{array}{l}\text { Tylocephalonyx } \\
\text { skinneri }\end{array}$ & $\begin{array}{l}\text { Ancylotherium } \\
\text { pentelicum }\end{array}$ & Other \\
\hline $\begin{array}{l}\text { Astragalar } \\
\text { symmetry }\end{array}$ & $\begin{array}{l}\text { Asymmetrical, } \\
\text { fibular side } \\
\text { hangs low }\end{array}$ & $\begin{array}{l}\text { Asymmetrical, } \\
\text { fibular side } \\
\text { not low }\end{array}$ & $\begin{array}{l}\text { Asymmetrical, } \\
\text { fibular side } \\
\text { low }\end{array}$ & $\begin{array}{l}\text { More } \\
\text { symmetrical, } \\
\text { fibular side } \\
\text { slightly low }\end{array}$ & $\begin{array}{l}\text { Variable, but } \\
\text { generally more } \\
\text { asymmetrical, } \\
\text { fibular side not } \\
\text { low }\end{array}$ & $\begin{array}{l}\text { M. fraasi from Steinheim } \\
\text { and } M \text {. bavaricum } \\
\text { from Viehhausen: } \\
\text { asymmetrical, } \\
\text { fibular side hangs low }\end{array}$ \\
\hline Astragalar neck & Very small & Moderate & Very small & Small & $\begin{array}{l}\text { Absent to very small } \\
\text { (but often larger } \\
\text { tibially) }\end{array}$ & Viehhausen: very small \\
\hline $\begin{array}{l}\text { Astragalar } \\
\text { proportions }\end{array}$ & Shorter & Taller & Shorter & Shorter & Shorter & $\begin{array}{l}\text { Viehhausen: medium- } \\
\text { shorter }\end{array}$ \\
\hline $\begin{array}{l}\text { Astragalus tibio- } \\
\text { volar process }\end{array}$ & Prominent & $\begin{array}{l}\text { Slightly } \\
\text { developed }\end{array}$ & Not strong & Not strong & Not strong & $\begin{array}{l}\text { Viehhausen: prominent; } \\
\text { Steinheim } M \text {. fraasi: } \\
\text { not strong }\end{array}$ \\
\hline $\begin{array}{l}\text { Calcaneal tuber } \\
\text { calcis }\end{array}$ & Moderate? & Long, rugose & $?$ & Moderate & Long & \\
\hline $\begin{array}{l}\text { Ectal facet of } \\
\text { calcaneum }\end{array}$ & $\begin{array}{l}\text { Broader than } \\
\text { tall }\end{array}$ & $\begin{array}{l}\text { Tall and } \\
\text { narrow }\end{array}$ & $\begin{array}{l}\text { Broad, } \\
\text { approaches } \\
\text { large } \\
\text { sustentacular } \\
\text { facet }\end{array}$ & $\begin{array}{l}\text { Broader than } \\
\text { tall }\end{array}$ & $\begin{array}{l}\text { Broad, displaced } \\
\text { fibularly onto } \\
\text { sustentacular } \\
\text { process }\end{array}$ & $\begin{array}{l}\text { Steinheim } M \text {. fraasi: } \\
\text { broader than tall }\end{array}$ \\
\hline $\begin{array}{l}\text { Articular facet } \\
\text { between cuboid } \\
\text { and Mt III }\end{array}$ & Yes, small & No & No & No & No? & Viehhausen: maybe? \\
\hline $\begin{array}{l}\text { Articular facet } \\
\text { between Mt IV } \\
\text { and } \\
\text { ectocuneiform }\end{array}$ & No & Yes & Yes & No & No & $\begin{array}{l}\text { Probably yes for Moropus } \\
\text { from France (St.-Gérand), } \\
\text { Portugal, Spain, and } \\
\text { Turkey }\end{array}$ \\
\hline $\begin{array}{l}\text { Mt III versus } \\
\text { Mt IV }\end{array}$ & $?$ & Subequal & Subequal & Mt III longest & Mt III longest & \\
\hline $\begin{array}{l}\text { Mt relative length } \\
\text { vs. width }\end{array}$ & Medium? & Longer & Shorter & Shorter & Shorter & $\begin{array}{l}\text { Moropus from Portugal, } \\
\text { Spain, and Turkey: longer }\end{array}$ \\
\hline
\end{tabular}

articular facet for even a rudimentary Mc V. The single, large facet for Mc III extends all the way from the dorsal to the volar edge.

\section{Hindlimb}

The proportions and morphology of the femur are very similar to those of M. elatus and $T$. skinneri. The size is close to that of smaller representatives of $M$. elatus. The femur of $A$. pentelicum figured by Roussiakis and Theodorou (2001) is proportionately shorter, and the axis of its shaft is slightly curved. Its patellar facet is wider and less symmetrical. The femur of A. pentelicum resembles no. 11636 in the strong ridge connecting the greater and third trochanters, but its lesser trochanter is weaker.

Coombs (1979) tabulated differences between the patellae of $M$. elatus and $T$. skinneri. The patella of the Sandelzhausen chalicothere resembles $T$. skinneri in its relatively broad trochlea with its two halves meeting at close to a right angle and in the strong ridge for the insertion of knee extensors. It resembles $M$. elatus in having a distal tongue at the patella apex. No patella of A. pentelicum has yet been described.

Astragali are relatively common in chalicothere collections, and therefore a number of comparisons are possible. The most similar specimen to the material from Sandelzhausen is the astragalus from Viehhausen (BSPG/ IPW no. 93) figured by Rinnert (1956). Like the Sandelzhausen astragali, it is clearly asymmetrical and has a very short neck, with the fibular side of the trochlea hanging distal to the neck. The irregular shape of the navicular facet and its curvature onto the tibial side of the bone are also extremely similar, as is a prominent tibio-volar process on the distal end. Facets for the calcaneum on the volar surface are also similar, with the ectal facet similarly separated from the sustentacular 
Table 8 Comparisons of astragalus proportions in selected Schizotheriinae

\begin{tabular}{|c|c|c|c|c|}
\hline Taxon/specimen & Max. width & Height tibial side & Tibial height/width & Source/reference \\
\hline \multicolumn{5}{|l|}{ Metaschizotherium bavaricum } \\
\hline BSPG 1959 II 11568 & 74.8 & 48.3 & 0.65 & Sandelzhausen, Germany \\
\hline BSPG 1959 II 11599 & 72.9 & 49.6 & 0.68 & Sandelzhausen, Germany \\
\hline BSPG 1959 II 11601 & 75.5 & 52.9 & 0.70 & Sandelzhausen, Germany \\
\hline BSPG/IPW no. 93 & 82.7 & 60.0 & 0.73 & Viehhausen, Germany \\
\hline \multicolumn{5}{|l|}{ Metaschizotherium fraasi } \\
\hline SMNS 5815 & 79.0 & 56.0 & 0.71 & $\begin{array}{l}\text { Steinheim, Germany/ } \\
\text { Koenigswald } 1932\end{array}$ \\
\hline \multicolumn{5}{|l|}{ Moropus elatus } \\
\hline AMNH 14378 & 89.9 & 74.7 & 0.83 & Agate, Nebraska, USA/Coombs 1978b \\
\hline CM 1701 & 76.7 & 68.8 & 0.86 & Agate, Nebraska, USA/Coombs 1978b \\
\hline F:AM/ACM $(N=9)$ & $81.1-98.0$ & $62.5-77.2$ & $0.77-0.82$ & Morava Ranch Quarry, Nebraska/Coombs 1978b \\
\hline \multicolumn{5}{|l|}{ Moropus hollandi } \\
\hline CM 1424 (holotype) & $\begin{array}{l}81.8(1) \\
84.1(r)\end{array}$ & $\begin{array}{l}61.1(1) \\
64.0(\mathrm{r})\end{array}$ & $\begin{array}{l}0.75(1) \\
0.76(r)\end{array}$ & Nebraska-Wyoming border, USA \\
\hline \multicolumn{5}{|l|}{ Moropus merriami } \\
\hline UCMP 11605 & 100.7 & 64.9 & 0.64 & Nevada, USA/Coombs $1978 \mathrm{~b}$ \\
\hline UCMP 19404 (part of syntype) & 102.6 & 62.2 & 0.61 & Nevada, USA/Coombs $1978 b$ \\
\hline \multicolumn{5}{|l|}{ Tylocephalonyx skinneri } \\
\hline F:AM 54976 & 83.8 & 54.8 & 0.65 & Greenside Quarry, Nebraska, \\
\hline F:AM 54936 & 81.8 & 52.7 & 0.64 & USA \\
\hline \multicolumn{5}{|l|}{ Ancylotherium pentelicum } \\
\hline PG 95/934 & 116.5 & 78.9 & 0.68 & Pikermi, Greece/Roussiakis and Theodorou 2001 \\
\hline PA $95 / 533$ & 104.7 & 70.2 & 0.67 & \\
\hline PA 95/535 (juvenile) & $\sim 88.3$ & 59.1 & 0.67 & Pikermi, Greece/Roussiakis and Theodorou 2001 \\
\hline NHMW no Nr. & 122 & 79 & 0.64 & Pikermi/Zapfe 1979 \\
\hline MTA AAP-53 & 101 & 70 & 0.69 & Pinaryaka, Turkey/Saraç et al. 2002 \\
\hline MTA MYS-74 & 108 & 65 & 0.60 & Salihpasalar, Turkey/Saraç et al. 2002 \\
\hline \multicolumn{5}{|l|}{ Ancylotherium cheboitense } \\
\hline CMK BAR 323’01 (holotype) & 113 & 72 & 0.64 & Baringo, Kenya/Guerin and Pickford 2005 \\
\hline \multicolumn{5}{|l|}{ Ancylotherium } \\
\hline IGME $400 \mathrm{M}$ & 90.8 & 67.4 & 0.74 & Valles de Fuentidueña, Spain/Alberdi et al. 1981 \\
\hline \multicolumn{5}{|l|}{ Borissiakia betpakdalensis } \\
\hline No Nr. & 68 & 58 & 0.85 & Betpakdala, Kazakhstan/Borissiak 1946 \\
\hline No Nr. & 92 & 74 & 0.80 & Betpakdala, Kazakhstan/Borissiak 1946 \\
\hline \multicolumn{5}{|l|}{ Schizotherium turgaicum } \\
\hline No Nr. & 43.5 & 38.5 & 0.89 & Kazakhstan/Belyaeva 1954 \\
\hline No Nr. & 47 & 41 & 0.87 & Kazakhstan/Belyaeva 1954 \\
\hline
\end{tabular}

Measurements in $\mathrm{mm}$

facet by a wide depression. However, the ectal facet is more deeply concave on the Viehhausen specimen. The astragalus from Steinheim (SMNS 5815), referred by von Koenigswald (1932) to M. fraasi, is also quite close but differs in having a more regularly rounded facet for the navicular and less development of the distal tibio-volar projection.
As shown in Table 8, astragali of M. elatus and more basal schizotheriines such as Borissiakia and Schizotheri$u m$ are proportionately much taller, especially on the tibial side; they also have a more developed neck. In M. elatus the fibular side of the trochlea does not extend lower than the neck. The navicular facet is pear-shaped and extends farther toward the fibular edge of the bone; there is some 
development of a distal tibio-volar projection, but it is less prominent. On the volar surface, the ectal facet is more deeply concave and the sustentacular facet more convex and less likely to be raised above the surface of the bone. Interestingly, astragali of the later species of Moropus, M. merriami, are quite similar in proportions and shape to the Sandelzhausen specimens. There are small differences in the shapes of the facets for the calcaneum and a larger difference in the navicular facet, which extends farther in the fibular direction than it appears to do in the Sandelzhausen astragali. M. merriami does not have a prominent tibio-volar process on the distal end.

Astragali of T. skinneri are more symmetrical than astragali referred to Moropus, Metaschizotherium, and most of those belonging to Ancylotherium. There is some modest development of a distal neck and slight distal overhang of the fibular side beyond the tibial side. The ectal facet for the calcaneum is transversely narrower, a character related to the greater symmetry of the astragalus.

Astragali referred to Ancylotherium show a range of proportions but generally have trochlear height at the low end for a schizotheriine (Table 8) and little to no development of a neck (there is much more evidence of a neck near its tibial edge). Symmetry can vary, but is generally greater than in the Sandelzhausen astragali; the fibular side of the trochlea does not generally hang lower distally than the tibial side, except in A. cheboitense Guérin and Pickford (2005) from Africa. The distal facet for the navicular extends much farther toward the fibular edge of the bone than in the astragali from Sandelzhausen. There is particular development of a tibio-volar projection. The astragalus figured by Alberdi et al. (1981) from the Valles de Fuentidueña (Vallesian) of Spain is taller than most specimens of Ancylotherium.

A wider, lower astragalus with a shorter neck evolves as a derived character within the Schizotheriinae and seems to occur in species in which the metatarsals have become shorter and stockier. The hindfoot as a whole in these animals becomes a bit shorter and broader. Asymmetry of the astragalus sometimes correlates with subequal lengths of Mt III and Mt IV and a possible shift in weight-bearing toward the outside of the foot; for example, M. elatus has an asymmetrical astragalus and Mt III and IV of subequal lengths, whereas T. skinneri has a more symmetrical astragalus and Mt III longer than Mt IV within a more mesaxonic hindfoot (Table 7). It is not clear, however, whether this relationship always holds true. In A. pentelicum the degree of asymmetry of the astragalus is variable, but in all known cases Mt III is the longest metatarsal. Compared to the Chalicotheriinae, in which even Early Miocene representatives have a strongly shortened, broad, asymmetrical astragalus and Mt IV longer than Mt III, the Schizotheriinae are much more conservative throughout their history despite astragalar proportions trending in a similar direction. None of the Schizotheriinae except Borissiakia has a distal articulation on the astragalus for the cuboid, whereas members of the Chalicotheriinae do have such a facet.

von Koenigswald (1932) figured a partial calcaneum (SMNS 5815) associated with the astragalus of $M$. fraasi noted above from Steinheim. This calcaneum resembles the specimens from Sandelzhausen; the ectal facet is raised above the surface of the tuber calcis much as in 11598 and more than in 11569. M. elatus is remarkable in having a very long tuber calcis with a highly rugose end. The ectal facet is taller but narrower than that in the Sandelzhausen specimens and extends farther onto the tuber calcis, where it is elevated above the surface so that contact with the tibia might occur. M. merriami is more like the Sandelzhausen specimens in having a shorter ectal facet that does not extend far onto the tuber calcis. However, in M. merriami the ectal facet is broader and extends quite far in the tibial direction, coming close to or contacting the sustentacular facet. Contact with the tibia at the end of ectal facet was clearly possible and in some cases is clearly delineated by a facet (Coombs 2004). T. skinneri resembles M. merriami in having a broad rather than tall ectal facet; there is some potential contact with the tibia, but only on the tibial edge of the ectal facet (Coombs 1979). A. pentelicum, as figured by Roussiakis and Theodorou (2001), has an easily distinguishable calcaneum in which the ectal facet is displaced in the fibular direction to such a degree that much of the facet is actually on the sustentacular process. In consequence, the sustentacular facet is relatively small and seems nearly continuous with the ectal facet. The calcaneal facet is well developed, with much of it tibial to the ectal facet. Like M. elatus, A. pentelicum has a long tuber calcis. There is some potential articulation with the tibia (Roussiakis and Theodorou 2001).

Two previously published European schizotheriine cuboids bear special comparison with the Sandelzhausen cuboid. The first is BSPG/IPW no. 93, from Viehhausen, figured by Rinnert (1956). Although little can be determined from the figure, I was able to examine and photograph this cuboid in 1972. The volar part of the bone is broken off, so the extent of the tibio-volar process cannot be determined. The facets on this bone compare relatively well with those of the Sandelzhausen cuboid, though the distal facet, for Mt IV, appears wider. My notes concerning this specimen do not mention a possible facet for Mt III, but reexamination of the photos suggests that such a facet might be present. Further examination of this specimen is warranted. Rinnert showed this specimen in articulation with a bone she identified as the proximal end of Mt IV. Unfortunately this bone was not available during my visit in 1972 , so I was not able to ascertain whether it was correctly identified. It looks too small in Rinnert's figure to 
belong with the cuboid. Belinchon and Montoya (19891990) described and figured a cuboid from Buñol (Spain). Their description of the navicular facet as occupying twothirds of the tibial surface of the bone suggests that this facet is larger than that on the Sandelzhausen cuboid. Belinchon and Montoya did not describe any facet for Mt III. The tibio-volar process is strong and rugose; Belinchon and Montoya noted a deep groove for insertion of the lateral peroneal muscle in this area.

Coombs (1978b) figured cuboids of Moropus distans (now referred to M. oregonensis), M. elatus, and M. hollandi. In M. elatus and M. hollandi the calcaneum facet on the proximal surface is pear-shaped and extends farther in the volar direction than its counterpart on the Sandelzhausen cuboid, no. 11557. The navicular facet forms a longer dorsal-to-volar band than in no. 11557, and the ectocuneiform facet differs in having dorsal and volar divisions that vary in their degree of separation. M. oregonensis and M. merriami resemble each other in having the navicular facet reach the proximal surface and thus adjoin the calcaneum facet, thus differing from M. elatus, M. hollandi, and no. 11557. None of the cuboids of Moropus has any evidence of a facet for Mt III. Cuboids of T. skinneri, like no. 11557, have a calcaneum facet that does not extend strongly in the volar direction, a navicular facet that does not reach the proximal surface, and an ectocuneiform facet that forms a longer dorso-volar band than the navicular facet and is not subdivided. Unlike no. 11557 , the ectocuneiform facet of $T$. skinneri does not contact the facet for Mt IV. Although the cuboid and Mt III must have come quite close to each other in T. skinneri, there is no evidence on either bone of a facet between them.

The remains of Mt III and especially Mt IV from Sandelzhausen can be compared with known remains of a variety of schizotheriines from four continents (Table 7). Unfortunately breakage prevents length measurements of Mt III and Mt IV of the Sandelzhausen chalicothere, so their proportions cannot be compared quantitatively with published values for other materials (Coombs 1989; Kaya 1993; Albright 1999; Guérin and Pickford 2005: all Mt IV). Nonetheless, qualitative comparison suggests that these two metatarsals have intermediate proportions between relatively long slender metatarsals (such as those of M. elatus) and shorter wider ones (such as those of T. skinneri, M. merriami, A. pentelicum, and especially Ancylotherium cheboitense).

In Europe and Southwestern Asia, Miocene chalicotheres with the proportionately most slender metatarsals include: (1) Mt IV from St. Gérand-le-Puy (MN2a, France) referred by Coombs (1974) to Moropus sp., (2) Mt IV from Charneca do Lumiar (MN4, Portugal) referred to Phyllotillon naricus by Antunes (1966) and ?Moropus sp. by
Coombs (1974), (3) Mt IV from Seyitömer-Kütahya (?Astaracian, Turkey) referred to Moropus elatus by Kaya (1993), and (4) Mt III and IV from Alto de Ballester I, Rubielos de Mora (MN3, Spain) referred to Moropus sp. by Montoya et al. (1996). Other known metatarsals with these proportions and general morphology are those of M. elatus and $M$. cf. oregonensis from the earliest Miocene of North America (Coombs 1978b; Albright 1999; Coombs et al. 2001). All of these metatarsals, with the potential exception of the specimen from Turkey, are earlier than the Sandelzhausen chalicothere. The Mt IV specimens generally show evidence of articulation with the ectocuneiform, the only possible exception to this being $M$. cf. oregonensis, where the evidence is equivocal (Coombs et al. 2001). In cases where the Mt IV and ectocuneiform articulate, any contact of Mt III with the cuboid, as in the Sandelzhausen specimens, is unlikely. Contact of Mt IV and the ectocuneiform in Moropus is usually associated with subequal lengths of Mt III and Mt IV and the probable ability to abduct Mt IV slightly.

More robust metatarsals than those of the Sandelzhausen chalicothere occur in M. merriami, T. skinneri, A. pentelicum, and A. cheboitense. M. merriami resembles other species of Moropus in having an articular facet for the ectocuneiform on Mt IV (Coombs 2004); it is unusual in having completely confluent dorsal and volar parts of the articular facet between Mt III and Mt IV. In T. skinneri Mt III is the longest metatarsal, and the articulation between Mt III and Mt IV interlocks tightly, with no contact of Mt IV with the ectocuneiform or Mt III with the cuboid. This also seems to be the case in A. pentelicum, which is also distinguishable in the flattened, somewhat concave shaft shapes of Mt III and IV. A. pentelicum has a very wide articulation between Mt IV and the cuboid. The most squat metatarsals found in the Schizotheriinae belong to A. cheboitense from the Late Miocene of Africa (Guérin and Pickford 2005); Mt III is clearly the longest of three associated metatarsals in the holotype of this species.

Mt IV proportions of the Sandelzhausen chalicothere appear to resemble those of Chemositia tugenensis, a Late Miocene African taxon established by Pickford (1979). This similarity is interesting considering the spatial and geographic difference between the two. I cannot be sure whether the Mt IV of C.tugenensis articulated with the ectocuneiform, but illustrations of this element (Pickford 1979; Guérin and Pickford 2005) suggest that it did not.

Phalanges

Fusion of the proximal and middle phalanges of digit II of the manus to form a duplex is a synapomorphy that defines a suite of schizotheriine chalicotheres that includes Metaschizotherium, Moropus, Phyllotillon, Tylocephalonyx, and 
Ancylotherium. Members of the Chalicotheriinae never have a duplex, nor do the more basal schizotheriines Schizotherium and Borissiakia.

Although the manus duplex has not been previously described for Metaschizotherium, undescribed duplexes beyond the three specimens from Sandelzhausen are available. Two of these, BSPG 1974 I 24 from Thannhausen, Germany (MN6), and BSPG 1961 I 485b from Buchdorf, Germany (uncertain age; see locality information under $\mathrm{Mc}$ II), are figured here for comparative purposes (Fig. 12d-f). It is not clear whether these specimens are attributable to $M$. fraasi or $M$. bavaricum. Both resemble the Sandelzhausen material in most respects, but are a bit more asymmetrical (especially the Buchdorf specimen). Both show strong development of the ulnar tubercle at the proximal end, an area that is damaged in the Sandelzhausen specimens, and have a weaker radial tongue.

Before continuing with comparisons of additional isolated manus duplexes from Eurasia, it is useful to comment on this bone in M. elatus, T. skinneri, and A. pentelicum, all species in which several such duplexes are found amid a variety of postcranial remains. All taxa for which multiple remains are known show some variation in symmetry, length versus width and depth proportions, and facet shape, so clear identification of isolated duplexes is probably not possible.

Moropus elatus has a proportionately long, slender duplex that is more symmetrical than those from Sandelzhausen, Thannhausen, and Buchdorf. The suture between the proximal and middle phalanges is readily visible externally in most cases, and the original proportions of the two phalanges are retained (Coombs 1978b; Coombs and Rothschild 1999). It is possible that duplex fusion had appeared relatively recently in the history of this group; some relatively young but full-sized individuals have not yet fused these bones (Coombs and Rothschild 1999). Although the border of the radial side of the proximal facet is lower than the ulnar side, no radial tongue is present in M. elatus. Three duplexes of Phyllotillon naricus from the Bugti Beds of Pakistan are available in the British Museum of Natural History, London; ForsterCooper (1920) figured one of them in side view. These duplexes, the only described postcranials definitely attributable to $P$. naricus, resemble those of M. elatus quite closely. Manus duplexes from Buñol [MN4 of Spain; Belinchon and Montoya (1989-1990)] and Alto de Ballester I, Rubielos de Mora [MN3 of Spain; Montoya et al. (1996)] have somewhat the same appearance as duplexes of M. elatus and P. naricus, consistent with their Early Miocene ages.

Manus duplexes of T. skinneri are strongly fused in external view, and their proportions are somewhat shortened. These duplexes show considerable asymmetry, especially at the proximal end. Coombs (1979) described and illustrated an "ulnar tongue" on the proximal facet of the duplex of T. skinneri. While this tongue clearly occurs, the "ulnar" designation is unfortunately incorrect. This tongue is actually on the radial (=medial) side and articulated with the small radial side of the asymmetrical distal facet on Mc II; it therefore is designated here as the radial tongue. In T. skinneri the ulnar tubercle on the proximal end is much better developed than the radial tubercle opposite the radial tongue. One of the syntypes of M. merriami illustrated by Merriam (1911) is a broken manus duplex, UCMP 19406. This broken specimen shows development of a radial tongue similar to that of no. 11561 from Sandelzhausen. Other, still undescribed, manus duplexes belonging to M. merriami in the University of California Museum of Paleontology show a morphological range similar to that of duplex specimens from Sandelzhausen, Buchdorf, and Thannhausen and may provide the closest morphological match. A few of these duplexes, however, are very large and much more robust.

Gaudry (1862), Schaub (1943), and Roussiakis and Theodorou (2001) have figured typical manus duplexes of A. pentelicum. These duplexes are relatively long, as in $M$. elatus and P. naricus, and symmetrical, without major differences between the radial and ulnar sides of the Mc II facet and proximal tubercles. Manus duplexes of A. pentelicum average slightly shallower in the depth of the shaft relative to length than those from Sandelzhausen, Buchdorf, and Thannhausen. In side view, the large distal facet extends abruptly in the volar direction from the shaft. Two isolated manus duplexes from Austria are of interest here. The first, described as Ancylotherium sp. by Zapfe (1967) from the Leithakalk of Kaisersteinbruch in the Vienna Basin, actually more closely resembles material of Metaschizotherium from Germany. It has unusually strong lateral protuberances along the coossified area of both sides of the shaft. The other, described as Ancylotherium (Metaschizotherium) sp. by Zapfe (1974) from the vicinity of Krems, has a shape more like a manus duplex of Ancylotherium, but with less volar extension of the distal facet relative to the shaft.

Fusion of the proximal and middle phalanges of digit II of the pes is known in Moropus, Metaschizotherium, and Tylocephalonyx. It occurs in about $11 \%$ of M. elatus and $60 \%$ of T. skinneri, and in all known cases of M. merriami (Coombs and Rothschild 1999; Coombs 2004). The percentage occurrence in Metaschizotherium is not certain because of the difficulty of allocating unfused phalanges to the correct digit, but it was certainly common and may have been universal. Despite the existence of a number of duplexes belonging to the manus of A.pentelicum, no duplex of the pes has yet been observed in that species. 
In addition to the Sandelzhausen pes duplex, no. 11562, there is another pes duplex from Häder, NMA 86-356-761, which von Koenigswald (1932, pl. 2 Fig. 22) figured and wrongly attributed to digit II of the manus of a chalicotheriine. This duplex is in fact a very close match to 11562 . von Koenigswald (1932: pl. 2 Fig. 21) also figured another pes duplex from Steinheim, attributing it to digit II of the manus of $M$. fraasi. This phalanx is proportionately shorter and wider than the pes duplexes from Sandelzhausen and Häder. This difference could possibly be a useful character to differentiate $M$. bavaricum from $M$. fraasi, but it could instead indicate variation in the proportions of these duplexes. In this context, it is particularly interesting to note different proportions of pes duplexes of $M$. merriami from North America (Coombs 2004). The more slender pes duplex of $M$. merriami resembles the specimens of Metaschizotherium from Sandelzhausen and Häder, while the more robust duplexes are similar to von Koenigswald's figured specimen of $M$. fraasi from Steinheim. In pondering the variation in M. merriami, Coombs (2004) considered the possibility that fusion of proximal and middle phalanges might occur on additional digits but could not resolve this issue. This option also remains open for Metaschizotherium but is not demonstrated.

\section{Taxonomic discussion}

Both dental and postcranial characters clearly place the Sandelzhausen chalicothere in the Schizotheriinae. Up until now, Early and Middle Miocene European Schizotheriinae have been represented only by fragmentary material. The Sandelzhausen chalicothere thus represents a special opportunity to begin the synthesis of scattered information into a more coherent whole. This process is still in an early stage, but several projects currently in progress are bringing together different parts of the story.

Four different genera have been used for Early and Middle Miocene European schizotheriine remains: Phyllotillon, Moropus, Metaschizotherium, and Ancylotherium. One purpose of the comparisons above has been to place the Sandelzhausen chalicothere within this context. Phyllotillon Pilgrim (1910), from the earliest Miocene Bugti Bone Beds of Pakistan, is known so far only from cheek teeth, parts of the mandible, and duplex phalanges of the manus. It is much earlier in age than the Sandelzhausen chalicothere and more plesiomorphic in many aspects of its dentition. Phyllotillon in a few cases has a crochet on the upper molars, a derived character that is much more frequent in Ancylotherium but does not occur in the Sandelzhausen chalicothere. It is thus clear that the Sandelzhausen chalicothere is not Phyllotillon. Unfortunately Phyllotillon is too poorly known to compare with its contemporaries from Europe. Coombs (1989) suggested that the name Phyllotillon be restricted to the Bugti collections from Pakistan until better material could provide a clear morphological linkage with other schizotheriine chalicotheres. I continue this proposal here.

Coombs (1974) identified material from St.-Gérand-lePuy (MN2a), France, as Moropus sp. In particular, I noted the presence of an articulation between the ectocuneiform and Mt IV as linking the Mt IV from St.-Gérand with Moropus, a genus in which Mt III and Mt IV are subequal in length. On the same basis I linked an Mt IV from Charneca do Lumiar (MN4), Portugal (Antunes 1966) to Moropus, and this idea has been continued by Kaya (1993) and Montoya et al. (1996). Although the relative lengths of Mt III and IV cannot be determined for the Sandelzhausen chalicothere, the one specimen with an articulating Mt III and Mt IV shows that Mt IV did not articulate with the ectocuneiform. Instead, there was a tiny articulation between the Mt III and cuboid. If this criterion for identifying Moropus is reliable, then the Sandelzhausen chalicothere should not be referred to Moropus. It is, however, important to note that in other respects the Sandelzhausen chalicothere is more similar to Moropus than to any other chalicothere genus, though a great many of the similarities are plesiomorphic. It is particularly and tantalizingly similar to its North American contemporary $M$. merriami; for example, both have two morphologies of the smaller phalangeal duplex usually associated with digit II of the pes. Despite the fact that Moropus is by far the best-known schizotheriine genus, it embraces a number of species whose interrelationships to each other are still under analysis.

Metaschizotherium von Koenigswald (1932) included M. fraasi and M. bavaricum, both identified on limited dental remains and phalanges from Steinheim (MN7), Häder (MN5), and Stätzling (MN6) in Germany. Careful comparison of the teeth of the Sandelzhausen chalicothere with von Koenigswald's type material confirms that it belongs within Metaschizotherium. von Koenigswald (1932) also included schizotheriine teeth from La Grive St.-Alban (MN7/8; France) within M. fraasi. These teeth are on average distinctly larger than material referred to Metaschizotherium from Sandelzhausen and the other German localities (Tables 1 and 2). Size difference would not necessarily be significant because of sexual dimorphism in chalicotheres (Coombs 1975). However, there are also some morphological differences, such as the common presence of an upper molar crochet in the La Grive material that is not seen in German material of Metaschizotherium. I conclude that the La Grive schizotheriine does not belong in M. fraasi and most likely should not be referred to Metaschizotherium at all. It might represent an early species of Ancylotherium but should be reevaluated in detail and with an open mind. 
Thenius (1953) originally suggested that Metaschizotherium was a junior synonym of Ancylotherium. He was followed in this hypothesis by Zapfe $(1967,1974)$ and Coombs (1974). The reasoning behind this hypothesis focused on derived characters then thought to be shared between Metaschizotherium and Ancylotherium; for example, the crochet in the La Grive schizotheriine (see preceding paragraph) is shared with Ancylotherium. The lunate of Metaschizotherium figured by Rinnert (1956) seemed to show a reduced volar process in common with Ancylotherium. Study of the lunate material of the Sandelzhausen chalicothere, however, shows that the volar process is not reduced to any great degree, and in a broader sense the manus retains evidence of a separate trapezium and lacks the numerous pronounced specializations of Ancylotherium for flexion of the carpus and hyperextension of the digits. In these respects Metaschizotherium is very like Moropus. Metaschizotherium should not be referred to Ancylotherium. Removing Metaschizotherium from Ancylotherium does not, however, rule out the possibility that the two could be related in some way. Metaschizotherium does show a few characters, such as the beginning of molarization of P3 and P4 with the presence of a small hypocone on these teeth, that are taken to a greater extreme in Ancylotherium. Nonetheless, the additional characters of Metaschizotherium available through study of the Sandelzhausen material detract from rather than enhance the idea of relationship between Metaschizotherium and Ancylotherium.

No-one has suggested that Metaschizotherium is especially close to Tylocephalonyx Coombs (1979). This domeskulled chalicothere has only been identified in North America. The lack of any known skulls of Metaschizotherium precludes cranial comparisons. Tylocephalonyx does show some general similarities with Metaschizotherium, but is clearly autapomorphic in certain characters, such as the shortening and simplification of the premolar row, while Metaschizotherium is increasing the complexity of its premolars slightly. Another schizotheriine genus that bears consideration is the African genus Chemositia Pickford (1979). Very little of Chemositia is known, but despite its Late Miocene age, its Mt IV is very reminiscent of that of Metaschizotherium.

The differentiation between $M$. fraasi and M. bavaricum is not easily resolved. von Koenigswald (1932) differentiated the two mostly on size. Coombs $(1974,1989)$ was skeptical of this division in light of the small size difference, the scarcity of specimens, and the ubiquity of size sexual dimorphism in chalicotheres (Coombs 1975). Despite my earlier reservations, study of the Sandelzhausen chalicothere has led me to believe that $M$. bavaricum is likely to be a valid species, representing an earlier, slightly smaller species of Metaschizotherium. None of the
Sandelzhausen material is particularly large; the largest ones overlap the lower end of the size range of $M$. fraasi (Tables 1 and 2). Furthermore, the comparisons show that resemblances of the Sandelzhausen chalicothere are closer to specimens from MN5 localities such as Viehhausen and Häder than they are to those from MN7 localities such as Steinheim; for example, upper premolar morphology and wear is very similar in specimens from these three localities. Unfortunately there is very little material of M. bavaricum from Viehhausen and Häder, so the comparisons are necessarily limited. It is very difficult to be certain which characters of the Sandelzhausen chalicothere are diagnostic at the generic versus the specific level.

The locality Petersbuch 71 (MN6) will be particularly important in resolving questions of variation and species resolution within Metaschizotherium. This chalicothere, which is under study by Ms. Julia Fahlke, is larger on average than the Sandelzhausen chalicothere and differs in some ways. Most interestingly, there is an ectocuneiform that shows evidence of an articulation for Mt IV (Fahlke, pers. comm.). My own studies of BSPG material of Metaschizotherium from Stätzling (MN6), Thannhausen (MN6), and Buchdorf (uncertain age) lead me to think that material from Stätzling (BSPG 1957 VII 53, a broken left Mt II) probably represents $M$. bavaricum, while that from Thannhausen and Buchdorf may belong to M. fraasi or M. bavaricum.

Fejfar et al. (1997) attributed an additional earlier species of European schizotheriine to Metaschizotherium as M. wetzleri. This species is primarily known from lower jaws and teeth, most from the Early Miocene of Germany, though Fejfar et al. also tentatively included a set of upper cheek teeth from the Czech Republic in this species. For convenience, I have used the designation $M$. wetzleri in talking about this material, but further work needs to be done to evaluate where this taxon belongs. The teeth of the Sandelzhausen chalicothere differ sufficiently in morphology and proportions from those of M. wetzleri, and it is thus clear that the two are separate species. In fact all of the earlier Miocene schizotheriine material that has been described so far from Europe, from MN2a to MN4, seems different enough from the Sandelzhausen chalicothere to be placed in species separate from M. bavaricum or M. fraasi. Is Metaschizotherium wetzleri an appropriate name for all this material? Despite the difficulties of comparing teeth from one locality with pisiforms, cuboids, or metatarsals from another, I think it is not. Coombs (1974) included a juvenile mandible and an Mt IV from St.Gérand-le-Puy (France) in Moropus sp. At that time I compared this mandible with juvenile mandibles of $M$. wetzleri (at that time thought to be Chalicotherium wetzleri; see Butler 1965) from Ulm (Germany) and observed differences between the two. Thus, given the rare opportunity to 
compare corresponding elements, I did not synonymize them. While further analysis of Early Miocene European schizotheriine material is beyond the scope of the present paper, I still support the idea that Moropus was present in Europe during that time. A separate species, M. wetzleri, was also apparently present. It is likely that the two (or more) species had different biogeographic and/or temporal ranges, but more study is necessary.

After MN7, there is little material from Europe that is clearly referable to Metaschizotherium. The questionable referral of the La Grive schizotheriine (MN7/8) has been noted above. Another specimen that should be viewed carefully is the manus duplex from Krems, Austria (MN9) described by Zapfe (1974). Although Metaschizotherium is easily differentiated from A. pentelicum, the highly specialized Turolian species of Ancylotherium that is relatively common in Southeastern Europe and Western Asia, it might be harder to distinguish forerunners of this species that reached Europe somewhat earlier; for example, Alberdi et al. (1981) attributed an astragalus from the Vallesian of Spain to Ancylotherium. Currently there are very few schizotheriine chalicothere fossils known from Europe in the MN8 through MN11 time span, and those that are known deserve special attention.

Although the presence of a duplex on the manus links the schizotheriine genera Moropus, Phyllotillon, Metaschizotherium, Tylocephalonyx, and Ancylotherium, more detailed relationships among these taxa are still unclear. Currently, as part of another study, I am coding schizotheriine characters for a computer-generated cladistic analysis. The Sandelzhausen chalicothere will continue to provide important data for this ongoing work.

\section{The ecological context of $M$. bavaricum at Sandelzhausen}

The schizotheriine chalicothere $M$. bavaricum is useful in several ways to our understanding of the Sandelzhausen deposit and the environment in which it was deposited. First, it is essential to understand the general appearance of this animal in life. Zapfe (1979) created a well-known and fascinating chalicothere reconstruction that has profoundly influenced the public and professional view of chalicotheres in Europe. This reconstruction shows a "horse-gorilla" (Tassy 1978), with very long forelimbs, short hindlimbs, and the manus held in a partial knuckle-walking position. This vision of a chalicothere is appropriate to members of the Chalicotheriinae, such as the Neudorf material from Slovakia that Zapfe studied in his monograph. It has, however, occasionally been incorrectly extended to the Schizotheriinae, for example by Fejfar et al. (1997). As a member of the Schizotheriinae, the Sandelzhausen
Fig. 15 Reconstructions of Moropus, a Miocene schizotheriine chalicothere. a Mounted skeleton of M. elatus, best known from Nebraska, USA (from Osborn 1919). b Habitat reconstruction of M. elatus (from Coombs 1983, drawn by Henry Galiano, by permission of the American Philosophical Society, Philadelphia, Pennsylvania, USA). Metaschizotherium bavaricum was smaller than M. elatus and lived in a moister, more closed environment, but its mode of life was probably similar

chalicothere, M. bavaricum, did not look like this. Its appearance would have been closer to that of Moropus elatus from North America. Skeletal reconstructions of M. elatus (Osborn 1919, 251, Fig. 15A) show an animal much more like an okapi (Okapia, Giraffidae), a browsing animal that lives today in rain forests of Africa. M. bavaricum was on average smaller than M. elatus, and we do not know the relative length of its neck, because few vertebrae are available. Nonetheless we can say that the forelimbs of $M$. bavaricum were only slightly longer than the hindlimbs and that the animal generally stood on the distal ends of the metapodials, buttressed by sesamoids, and hyperextended the phalanges in a hook-like manner so that the claws were mostly held clear of the ground. Schaub (1943) showed this mechanism well for A. pentelicum, but the hand of M. bavaricum lacks most of the strong specializations of A. pentelicum and thus is more similar to that of $M$. elatus.

It is important to note that no specimens of the Chalicotheriinae occur at Sandelzhausen. Heissig (1997) suggested that no members of the Chalicotheriinae were present in the Early Miocene of Europe and that this group arrived sometime during late MN5. The Sandelzhausen chalicothere at approximately $16 \mathrm{Ma}$ presumably would not have had any contact with members of the Chalicotheriinae. Later representatives of Metaschizotherium coexisted to some degree with chalicotheriines and sometimes are found in the same deposits, for example at Stätzling (MN6) and Thannhausen (MN6). Occasional cooccurrences suggest that the ecological requirements of Metaschizotherium and its European chalicotheriine contemporaries were not vastly different. Over time, members of the chalicotheriine genera Anisodon and Chalicotherium became increasingly prevalent, especially in Central Europe.

Chalicothere fossils are generally regarded as indicators of treed environments. This view seems correct for members of the Chalicotheriinae. The Schizotheriinae were apparently broader in their ecological requirements. Some seem likely to have lived in closed forests. On the other hand, $M$. elatus lived in seasonally dry environments of the North American Great Plains and A. pentelicum is found in mixed environments that appear to have been open woodlands in Southeastern Europe and Western Asia. Where then might $M$. bavaricum fit in the ecological spectrum of the Schizotheriinae? 

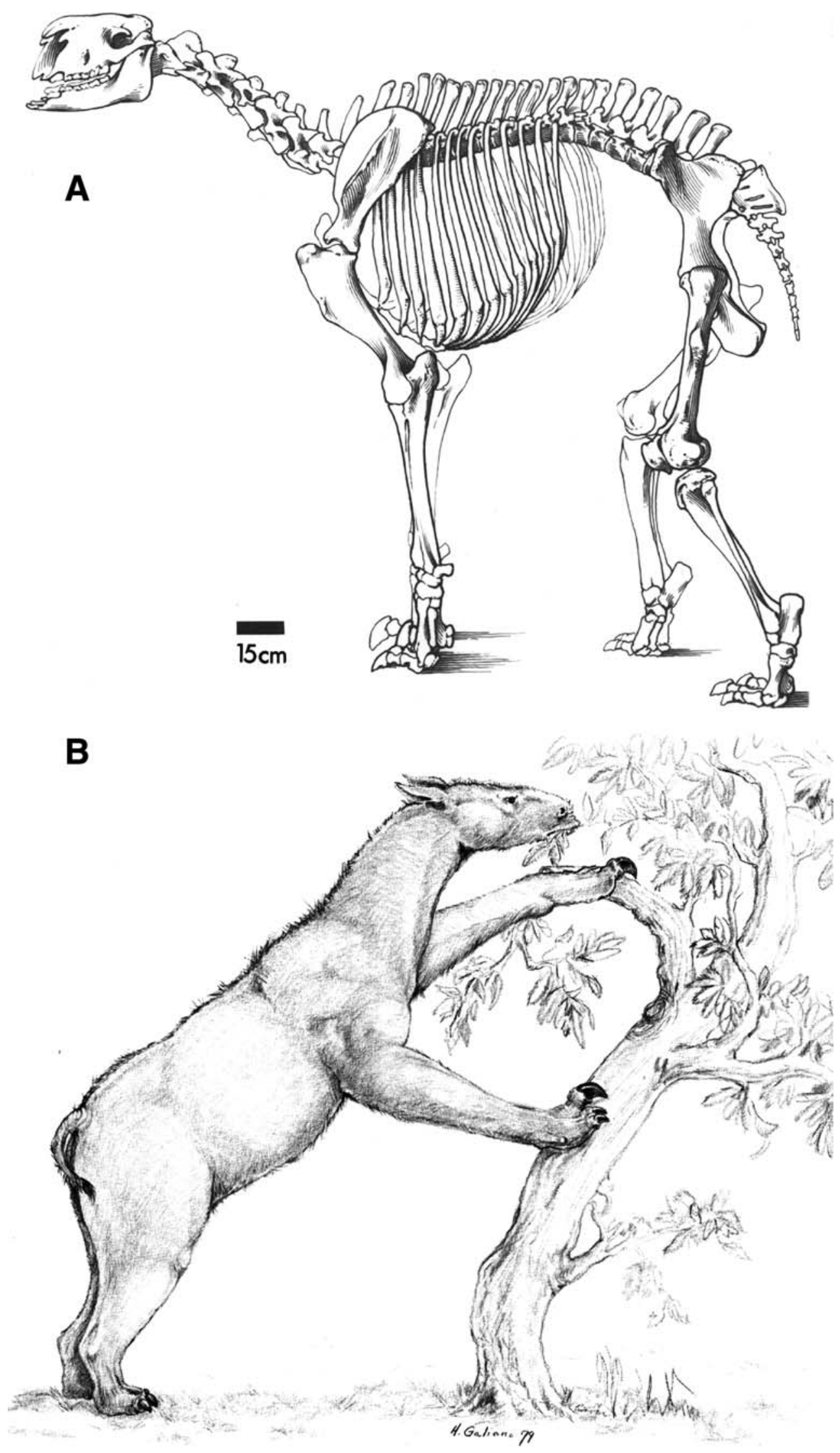
Investigation of paleodiet is one way that paleontologists are placing extinct animals in an environmental context. Dental mesowear, microwear, and isotope studies have all shed light on paleodiets. As part of a low-magnification stereomicroscopic study of dental microwear in chalicotheres (Coombs and Semprebon 2005; Semprebon et al. in preparation), I molded teeth of the Sandelzhausen chalicothere and included M. bavaricum in our larger study. Casts of the molds were then examined on a stereomicroscope at $35 \times$, using the methodology described by Solounias and Semprebon (2002) and Semprebon et al. (2004). Briefly, this study suggests that most Miocene Schizotheriinae such as Moropus elatus and Tylocephalonyx skinneri fed on leaves, bark, and twigs, while Chalicotheriinae such as Anisodon grande and Chalicotherium goldfussi have medium- and large-sized puncture pits and scratch textures that suggest hard fruit and/or seed browsing. M. bavaricum shows a bimodal distribution in the number of tooth scratches; similar bimodality occurs in extant fruit browsers and in seasonal or regional mixed feeders. There are numerous puncture pits also suggestive of hard fruit browsing. There is only modest evidence (in the form of coarse and hypercoarse scratches) for bark and twig consumption. Thus $M$. bavaricum resembles members of the Chalicotheriinae found later in the same region in apparently feeding on hard fruit, though it lacks the very coarse wear found in A. grande and C. goldfussi. The microwear results also show little of the kind of pitting and gouging that is caused by environmental grit taken in with food in open habitats. We can therefore assume that the Sandelzhausen ecosystem represented a relatively closed, treed environment without a great deal of dust.

The microwear results are reasonably consistent with those from other recent studies. Schulz (2009) and Schulz et al. (2007) performed a mesowear analysis on M. bavaricum from Sandelzhausen and $M$. fraasi from MN6 karst fissure fillings at Petersbuch 71 in the Franconian Alb. Mesowear of both species suggested a diet with relatively soft dicotyledon leaves and shoots complemented by more abrasive fibrous materials that these authors attributed to twigs, bark, and branches. The abrasive component of the diet was less, however, than that of the Chalicotheriinae included in their study. A stable isotope analysis of tooth enamel of large mammals from Sandelzhausen by Tütken and Vennemann (2009) showed a relatively low mean $\delta^{13} \mathrm{C}$ value for $M$. bavaricum, which thus most likely fed on vegetation in partially closed forests. Oxygen isotope values suggested that M. bavaricum was a water-dependent browser in a warm humid environment with low seasonality. Neither the mesowear nor the stable isotope studies indicated the degree of fruit browsing suggested by the microwear results. Broad studies of community structure in MN5 German Molasse Basin faunas point toward the development of warm, humid, browser-dominated forested wetlands in this region (Eronen and Rössner 2007; Kaiser and Rössner 2007). Such communities attained their greatest diversity in MN6.

The unexpected presence of claws in chalicotheres has led to much speculation about their mode of life. Zapfe (1979) and many others have made a good case for bipedal browsing in the Chalicotheriinae. The Schizotheriinae are less bizarre in their postcranial morphology, but bipedal browsing also seems a reasonable interpretation for them, as suggested by Borissiak (1945) and Coombs (1983). In this context, the claws would be used in a hook-like manner for pulling down branches or gripping bark (Fig. 15b). There is little dental evidence (in the form of wear by heavy grit) or postcranial specialization (in the form of force adaptations of the forelimb) for digging in either the Chalicotheriinae or the Schizotheriinae.

The presence of multiple specimens of some elements allows the possibility of recognizing variation within $M$. bavaricum over a relatively short time interval in one area. In particular there is variation in the degree of molarization of the lower premolars. This kind of information is extremely useful in understanding which structures were relatively plastic and which were more fixed within this species. It can also prevent taxonomic oversplitting when more isolated specimens from other localities are compared. The ability to study variation, even on a small scale, is a luxury that is rare for European chalicotheres.

As noted above, the chalicothere elements at Sandelzhausen are generally disarticulated, and it is only occasionally possible to link certain parts together as parts of one individual animal. Another important feature of the profile of $M$. bavaricum at Sandelzhausen is the relatively large number of juvenile and subadult individuals. The preponderance of young animals is most evident in the jaws and teeth: the last molar is not usually fully erupted or in occlusion, and the permanent molars are not heavily worn. Some of the postcranials (for example, the scaphoid and lunate, no. 11570) also are clearly juvenile. The disarticulated preservation and young age profile show similarities to those of other large mammals from Sandelzhausen, such as rhinoceroses and proboscideans (K. Heissig, U. Göhlich, pers. comm.) and provide useful information for interpreting the taphonomy of the deposit. Another, still unexplored avenue of study is close examination of each bone for weathering, abrasion, breakage by carnivores or trampling, and other post mortem factors that could help in the reconstruction of conditions under which the Sandelzhausen Fossillagerstätte formed.

In light of the foregoing discussion, it is appropriate to return to the opinion expressed by Heissig (1999a) that Metaschizotherium represents a distinctive Central and Western European radiation of the Early to Middle 
Miocene. The Middle Miocene parts of this radiation from later MN5 to MN7, representing the known ranges of M. bavaricum and M. fraasi, are now becoming better understood. The likely presence of Moropus in Europe during the Early Miocene complicates our ability to recognize the earliest representatives of Metaschizotherium and deserves further study. My study of the Sandelzhausen chalicothere confirms Heissig's (1999a) view that there was a morphological, temporal, and geographic gap between Metaschizotherium and Late Miocene Ancylotherium pentelicum. Metaschizotherium (at least $M$. bavaricum) is typically associated with areas of closed moist forest, and A. pentelicum with drier, more open woodlands. During the Middle Miocene, the forested environments of Central Europe became more dominated by members of the Chalicotheriinae, while Metaschizotherium was in decline by the end of MN7 and eventually went extinct. The schizotheriine chalicothere material from La Grive St.-Alban (MN7-8; France) does not belong to Metaschizotherium and is pivotal to our understanding of later phases of schizotheriine evolution in Europe.

Acknowledgments First and foremost, I thank my Munich colleagues, Drs. Gertrud Rössner, Kurt Heissig, and Volker Fahlbusch for allowing me to work on the Sandelzhausen chalicothere and for inviting my participation in the Sandelzhausen Symposium 2005 in Mainburg, Germany. When Volker first allowed me to see the beginnings of the Sandelzhausen chalicothere collection in 1972, I was much impressed with the quality of the material. I never anticipated having the opportunity to publish on it, and doing so now, on a greatly augmented collection, has been a special privilege for me. Drs. Rössner, Heissig, and Fahlbusch also devoted much time to showing me the collections, explaining the mapping and cataloguing system, and answering in English my numerous questions. Dr. Ursula Göhlich provided useful insights on the Sandelzhausen proboscideans and located the chalicothere patellae that had strayed into the proboscidean collection. Careful reviews by Dr. Heissig and by Dr. Robert M. Hunt, Jr. helped to improve this manuscript. Mr. Georg Janssen of the BSPG kindly provided a large number of the photographic illustrations, Dr. Walter Coombs helped with additional photographs, and Mr. Eric Dewar gave computer support in production of the figures. I also thank the other members of the Sandelzhausen Symposium for their good fellowship and many stimulating thoughts on the Sandelzhausen fauna and its depositional environment. My research travel was funded by the Freunde der Bayerische Staatsammlung für Paläontologie und Historische Geologie München e.V. Grant funding from Deutsche Forschungsgemeinshaft (GZ 4850/88/05) financed my participation in the Sandelzhausen Symposium. I am grateful to the citizens of Mainburg and their mayor, Josef Egger, for their excellent hospitality. I thank Dr. Michael Rummel for allowing me access to collections at the Naturmuseum Augsburg and for allowing me to see his chalicothere collection from Petersbuch. I am also grateful to Ms. Julia Fahlke for sharing thoughts based on her study of the Petersbuch collection. In addition to my recent museum visits, the comparative part of my study has profited greatly by examination of relevant materials at other museums over the years, most particularly the Amherst College Museum of Natural History (Amherst), the American Museum of Natural History (New York), the University of California Museum of Paleontology (Berkeley), the British Museum of Natural History
(London), the Muséum National d'Histoire Naturelle (Paris), the Geologisch-Paläontologisches Institut der Universität Würzburg (Würzburg), the Staatliches Museum für Naturkunde (Ludwigsburg), the Landesmuseum Joanneum (Graz), and the Muséum d'Histoire Naturelle de Lyon (Lyon).

\section{References}

Alberdi, M.T., L. Ginsburg, and J. Morales. 1981. Rhinocerotidae del yacimiento de Los Valles de Fuentidueña (Segovia). Estudios Geologicos Madrid 37: 439-465.

Albright III, L.B. 1999. Ungulates of the Toledo Bend Local Fauna (Late Arikareean, Early Miocene), Texas Gulf Coastal Plain. Bulletin of the Florida Museum of Natural History 42: 1-80.

Antunes, M.T. 1966. Notes sur la géologie et la paléontologie du Miocène de Lisbonne. V. Un schizotheriiné du genre Phyllotillon (Chalicotherioidea, Perissodactyla) dans l'Helvétien V-b de Charneca do Lumiar. Remarques écologiques sur la faune de mammifères. Boletim de Sociedade Géologica de Portugal 16: $159-178$.

Bach, F. 1912. Chalicotherienreste aus dem Tertiär Steiermarks. Jahrbuch der Kaiserlich-Königlichen Geologischen Reichsanstalt 62: 681-690.

Belinchon, M., and P. Montoya. 1989-1990. Presencia de Phyllotillon naricus Pilgrim (Chalicotheriidae, Perissodactyla, Mammalia) en el Aragoniense de Buñol (Valencia). Breve síntesis de los calicotéridos en el registro español. Paleontologia i Evolució 23: 171-180.

Belyaeva, E.I. 1954. [Chalicotheres of the Soviet Union and Mongolia.]. Trudy Paleontologicheskovo Instituta Akademia Nauk USSR 55(3): 44-84.

Borissiak, A.A. 1945. The chalicotheres as a biological type. American Journal of Science 243: 667-679.

Borissiak, A.A. 1946. [A new chalicothere from the Tertiary of Kazakhstan.]. Trudy Paleontologicheskovo Instituta, Akademia Nauk USSR 13(3): 1-134.

Butler, P.M. 1965. Fossil mammals of Africa. No. 18. East African Miocene and Pleistocene chalicotheres. Bulletin of the British Museum Natural History Geology 10: 165-237.

Colbert, E.H. 1934. Chalicotheres from Mongolia and China in the American Museum. Bulletin of the American Museum of Natural History 67: 353-387.

Coombs, M.C. 1974. Ein Vertreter von Moropus aus dem europäischen Aquitanien und eine Zusammenfassung der europäischen postoligozänen Schizotheriinae (Mammalia, Perissodactyla, Chalicotheriidae). Sitzungsberichte der Österreichischen Akademie der Wissenschaften, Mathematisch-naturwissenschaftliche Klasse (Abt. I) 182: 273-288.

Coombs, M.C. 1975. Sexual dimorphism in chalicotheres (Mammalia, Perissodactyla). Systematic Zoology 24: 55-62.

Coombs, M.C. 1978a. A premaxilla of Moropus elatus Marsh, and evolution of chalicotherioid anterior dentitions. Journal of Paleontology 52: 118-121.

Coombs, M.C. 1978b. Reevaluation of early Miocene North American Moropus (Perissodactyla, Chalicotheriidae, Schizotheriinae). Bulletin of Carnegie Museum of Natural History 4: 1-62.

Coombs, M.C. 1979. Tylocephalonyx, a new genus of North American dome-skulled chalicotheres (Mammalia, Perissodactyla). Bulletin of the American Museum of Natural History 164: 1-64.

Coombs, M.C. 1983. Large mammalian clawed herbivores: a comparative study. Transactions of the American Philosophical Society 73(7): 1-96.

Coombs, M.C. 1989. Interrelationships and diversity in the Chalicotheriidae. In The Evolution of Perissodactyls, eds. Prothero, 
D.R., and R.M. Schoch, 438-457. Oxford/New York: Clarendon/ Oxford University Press.

Coombs, M.C. 2004. Moropus merriami in the early Barstovian Lower Snake Creek fauna of Nebraska, with comments on biogeography of North American chalicotheres. Bulletin of the American Museum of Natural History 285: 191-208.

Coombs, M.C., and B.M. Rothschild. 1999. Phalangeal fusion in schizotheriine chalicotheres (Mammalia, Perissodactyla). Journal of Paleontology 74: 682-690.

Coombs, M.C., and G.M. Semprebon. 2005. The diet of chalicotheres (Mammalia, Perissodactyla) as indicated by low magnification stereoscopic microwear analysis. Abstracts of Papers, 65th Annual Meeting, Society of Vertebrate Paleontology, Mesa, Arizona. Journal of Vertebrate Paleontology 25(Supplement to Number 3): 47A.

Coombs, M.C., R.M. Hunt Jr., E. Stepleton, L.B. Albright III, and T.J. Fremd. 2001. Stratigraphy, chronology, biogeography, and taxonomy of early Miocene small chalicotheres in North America. Journal of Vertebrate Paleontology 21: 607-620.

Depéret, C. 1892. La faune de mammifères Miocènes de la GriveSaint-Alban, Isère, et quelques autres localités du bassin du Rhone. Archives de Muséum d'Histoire Naturelle de Lyon 5(2): $1-93$.

Dietrich, W.O. 1942. Ältestquartäre Säugetiere aus der südlichen Serengeti, Deutsch-Ostafrika. Palaeontographica, Stuttgart 94A: 43-130.

Eronen, J.T., and G.E. Rössner. 2007. Wetland paradise lost: Miocene community dynamics in large herbivorous mammals from the German Molasse Basin. Evolutionary Ecology Research 9: 471494

Fahlbusch, V. 1976. Die obermiozäne Wirbeltierfundstelle Sandelzhausen. Zentralblatt für Geologie und Paläontologie, Teil II. 1976: 255-261.

Fahlbusch, V. 2003. Die miozäne Fossil-Lagerstätte Sandelzhausen Die Ausgrabungen 1994-2001. Zitteliana (A) 43: 109-122.

Fahlbusch, V., and H. Gall. 1970. Die obermiozäne Fossil-Lagerstätte Sandelzhausen. 1. Endeckung, Geologie, Faunenübersicht und Grabungsbericht für 1969. Mitteilungen der Bayerischen Staatsammlung für Paläontologie und historische Geologie 10: 365396

Fahlbusch, V. and R. Liebreich. 1996. Hasenhirsch und Hundebär. Chronik der tertiären Fossil-Lagerstätte Sandelzhausen bei Mainburg. Munich: Verlag Dr. Friedrich Pfeil, p 40.

Fahlbusch, V., H. Gall, and N. Schmidt-Kittler. 1972. Die obermiozäne Fossil-Lagerstätte Sandelzhausen. 2. Sediment und Fossilinhalt-Probleme der Genese und Ökologie. - Neues Jahrbuch für Geologie und Paläontologie, Monatshefte, 1972: 331-343.

Fejfar, O., E.P.J. Heizmann, and P. Major. 1997. Metaschizotherium cf. wetzleri (Kowalewsky) from the early Miocene of Czech Republic and South Germany. In Actes du Congrès BiochroM'97, Mémoires et Travaux de l'Ecole Practique des Hautes Etudes, Institut de Montpellier, vol. 21, eds. Aguilar, J.P., S. Legendre, and J. Michaux, 707-709.

Filhol, H. 1894. Observations concernant quelques mammifères fossils nouveaux du Quercy. Annales des Sciences Naturelles, Zoologie (ser. 7) 16: 129-150.

Forster-Cooper, C. 1920. Chalicotheroidea from Baluchistan. Proceedings of the Zoological Society of London 1920: 357-366.

Fraas, O. 1870. Die Fauna von Steinheim mit Rücksicht auf die miocenen Säugethier-und Vogelreste des Steinheimer Beckens. 54, 8 pls., Stuttgart: E. Schweizerbart'sche Verlagshandlung, E. Koch.

Garevski, R., and H. Zapfe. 1983. Weitere Chalicotheriiden-funde aus der Pikermi-fauna von Titov Veles (Mazedonien, Jugoslawien). Acta Musei Macedonici Scientarum Naturalium, Skopje 17: 1-20.
Gaudry, A. 1862. Animaux fossiles et géologie de l'Attique, 475, 75 plates. Paris: Libraire de la Societé Géologique de France.

Gaudry, A., and E. Lartet. 1856. Résultats des recherches paléontologiques entreprises dans l'Attique sous les auspices de l'Académie. Comptes Rendus de l'Académie des Sciences, Paris 43: 271-274.

Gill, T. 1872. Arrangement of the families of mammals with analytical tables. Smithsonian Miscellaneous Collections 11: 198.

Ginsburg, L. 1970. Les Mammifères des faluns helvétiens du Nord de la Loire. Comptes Rendus Sommaire des Séances de la Societé Géologique de France 1970(6): 189-190.

Ginsburg, L. 1999. Order Carnivora. In The Miocene Land Mammals of Europe, eds. Rössner, G.E., and K. Heissig, 109-148. Munich: Verlag Dr. Friedrich Pfeil.

Guérin, C., and M. Pickford. 2005. Ancylotherium cheboitense nov. sp., nouveau Chalicotheriidae (Mammalia Perissodactyla) du Miocène supérieur des Tugen Hills (Kénya). Comptes Rendus Palevol 4: 225-234.

Heissig, K. 1997. Mammal faunas intermediate between the reference faunas of MN4 and MN6 from the Upper Freshwater Molasse of Bavaria. In Actes du Congrès BiochroM'97, Mémoires et Travaux de l'Ecole Practique des Hautes Etudes, Institut de Montpellier, vol. 21, eds. Aguilar, J.-P., S. Legendre, and J. Michaux, 537-546.

Heissig, K. 1999a. Family Chalicotheriidae. In The Miocene Land Mammals of Europe, eds. Rössner, G.E. and K. Heissig, 189192, Munich: Pfeil.

Heissig, K. 1999b. Family Rhinocerotidae. In The Miocene Land Mammals of Europe, eds. Rössner, G.E. and K. Heissig, 175188, Munich: Pfeil.

Holland, W.J., and O.A. Peterson. 1914. The osteology of the Chalicotheroidea with special reference to a mounted skeleton of Moropus elatus Marsh, now installed in the Carnegie Museum. Memoirs of the Carnegie Museum 3: 189-406.

Hooker, J.J. 1994. The beginning of the equoid radiation. Zoological Journal of the Linnean Society 112: 29-63.

Hunt Jr., R.M. 1998. Amphicyonidae. In Evolution of Tertiary Mammals of North America, vol. 1: Terrestrial Carnivores, Ungulates. and Ungulatelike Mammals, eds. Janis, C.M., K.M. Scott, and L.L. Jacobs, 196-227. Cambridge: Cambridge University Press.

Hunt Jr., R.M. 2002. Intercontinental migration of Neogene amphicyonids (Mammalia, Carnivora): appearance of the Eurasian beardog Ysengrinia in North America. American Museum Novitates 3384: 1-53.

Kaiser, T.M., and G.E. Rössner. 2007. Dietary resource partitioning in ruminant communities of Miocene wetland and karst palaeoenvironments in Southern Germany. Palaeogeography Palaeoclimatology Palaeoecology 252: 424-439.

Kaup J.-J. 1833. Description d'ossements fossiles de mammifères inconnus jusqu'à présent qui se trouvent au Muséum grand ducal de Darmstadt, 2:31, Darmstadt: Heyer J.G.

Kaya, T. 1993. First record of Moropus elatus (ChalicotheriidaePerissodactyla) in Turkey (Seyitömer-Kütahya). Doga-Turk Yerbilimieri/Turkish Journal of Earth Science 2: 189-194.

Kaya, T., V. Tuna, and D. Geraads. 2001. A new late Orleanian/early Astaracian mammalian fauna from Kultak (Milas-Mugla), southwestern Turkey. Geobios 34: 673-680.

Kowalewsky, W. 1873. Monographie der Gattung Anthracotherium Cuv. und Versuch einer natürlichen Classification der fossilen Hufthiere. Palaeontographica (n. ser.) 22: 131-346.

Merriam, J.C. 1911. Tertiary mammal beds of Virgin Valley and Thousand Creek in northwestern Nevada. Part 2. Vertebrate faunas. University of California Publication. Bulletin of the Department of Geology 6: 199-304. 
Montoya, P., E. Peñalver, F.J. Ruiz-Sánchez, C. de Santisteban, L. Alcalá, M. Belinchón, and J.I. Lacomba 1996. Los yacimientos paleontológicos de la cuenca tertiaria continental de Rubielos de Mora (Aragón). Revista Española de Paleontología, No. Extraordinario, 215-224.

Moser, M., G.E. Rössner, U.B. Göhlich, M. Böhme, and V. Fahlbusch. 2009. The fossil lagerstätte Sandelzhausen (Miocene; southern Germany): history of investigation, geology, fauna and age. In Fossil lagerstätte Sandelzhausen (Miocene, southern Germany): Contributions to the fauna. Paläontologische Zeitschrift, eds. Rössner, G.E. and U.B. Göhlich 83(1).

Mottl, M. 1966. Neue Säugetierfunde aus dem Jungtertiär der Steiermark. VIII. Eine neue unterpliozäne Säugetierfauna aus der Steiermark, SO-Österreich. Mitteilungen des Museums für Bergbau Geologie und Technik am Landesmuseum 'Joanneum'. Graz 28: 33-62.

Mottl, M. 1970. Die jungtertiären Säugetierfaunen der Steiermark, Südost-Österreichs. Mitteilungen des Museums für Bergbau Geologie und Technik am Landesmuseum 'Joanneum Graz' 31: 1-92.

Osborn, H.F. 1919. Seventeen skeletons of Moropus; probable habits of this animal. Proceedings of the National Academy of Science 5: 250-252.

Pickford, M. 1979. New evidence pertaining to the Miocene Chalicotheriidae (Mammalia, Perissodactyla) of Kenya. Tertiary Research 2: 83-91.

Pilgrim, G.E. 1910. Notices of new mammalian genera and species from the Tertiaries of India. Records of the Geological Survey of India 40: 63-71.

Qiu Z., W. Wu, and Z. Qiu (1999) Miocene mammal faunal sequence of China: palaeozoogeography and Eurasian relationships. In The Miocene land mammals of Europe, eds. Rössner G.E., and K. Heissig, 443-455, Munich: Verlag Dr. Friedrich Pfeil.

Rinnert, P. 1956. Die Huftiere aus dem Braunkohlenmiozän bei Oberpfalz. Palaeontographica, Stuttgart 107A: 1-65.

Roussiakis, S.J., and G.E. Theodorou. 2001. Ancylotherium pentelicum (Gaudry and Lartet, 1856) (Perissodactyla, Mammalia) from the classic locality of Pikermi (Attica, Greece), stored in the Palaeontological and Geological Museum of Athens. Geobios 34: 563-584.

Saraç, G., T. Kaya, and D. Geraads. 2002. Ancylotherium pentelicum (Perissodactyla, Mammalia) from the Upper Miocene of central and western Turkey. Geobios 35: 241-251.

Schaub, S. 1943. Die Vorderextremität von Ancylotherium pentelicum Gaudry und Lartet. Schweizerischen Palaeontologischen Abhandlungen 64: 1-36.

Schulz, E. and J.M. Fahlke. 2009. The diet of Metaschizotherium bavaricum (Chalicotheriidae, Mammalia) from the MN5 of Sandelzhausen (Germany) implied by the mesowear method. In Fossil lagerstätte Sandelzhausen (Miocene, southern Germany): Contributions to the fauna-Paläontologische Zeitschrift, eds. Rössner, G.E. and U.B. Göhlich 83 (1).

Schulz, E., J.M. Fahlke, G. Merceron, and T.M. Kaiser. 2007. Feeding ecology of the Chalicotheriidae (Mammalia, Perissodactyla, Ancylopoda). Results from dental micro- and mesowear analyses. Verhandlungen des Naturwissenschaftlichen Vereins Hamburg 43: 5-31.

Semprebon, G.M., L.R. Godfrey, N. Solounias, M.R. Sutherland, and W.L. Jungers. 2004. Can low-magnification stereomicroscopy reveal diet? Journal of Human Evolution 47: 115-144.

Solounias, N., and G.M. Semprebon. 2002. Advances in the reconstruction of ungulate ecomorphology with application to early fossil equids. American Museum Novitates 3366: 1-49.

Tassy, P. 1978. Chalicotherium: le "cheval-gorille". La Recherche 87: $283-285$.

Tedford, R.H., L.B. Albright III, A.D. Barnosky, I. FerrusquiaVillafranca, R.M. Hunt Jr, J.E. Storer, C.C. Swisher III, M.R. Voorhies, S.D. Webb, and D.P. Whistler. 2004. Mammalian biochronology of the Arikareean through Hemphillian interval (Late Oligocene through Early Pliocene epochs). In Late Cretaceous and Cenozoic Mammals of North America: Biostratigraphy and Biochronology, ed. M.O. Woodburne, 232-314. New York: Columbia University Press.

Thenius, E. 1953. Studien über fossile Vertebraten Griechenlands. III. Das Maxillargebiss von Ancylotherium pentelicum Gaudry und Lartet. Annales Géologiques des Pays Helléniques 5: 97-106.

Tütken, T. and T. Vennemann. 2009. Stable isotope ecology of Miocene large mammals from Sandelzhausen, southern Germany. In Fossil lagerstätte Sandelzhausen (Miocene, southern Germany): Contributions to the fauna-Paläontologische Zeitschrift, eds. Rössner, G.E. and U.B. Göhlich 83 (1).

Viret, J. 1949. Quelques considerations preliminaires à propos de la revision de la faune des mammifères Miocènes de la Grive St.Alban. Bulletin Mensuel de la Societé Linnéenne de Lyon 18: 53-57.

Viret, J. 1961. Catalog critique de la faune des mammifères Miocènes de La Grive Saint-Alban (Isère). Nouvelles Archives Musée d'Histoire Naturelle de Lyon 6: 53-81.

von Koenigswald, G.H.R. 1932. Metaschizotherium fraasi n. g. n. sp., ein neuer Chalicotheriide aus dem Obermiocän von Steinheim a. Albuch. Bemerkungen zur Systematik der Chalicotheriiden. Palaeontographica, Beitrage zur Naturgeschichte der Vorzeit 8: $1-24$.

Xue, X-x, and M.C. Coombs. 1985. A new species of Chalicotherium from the upper Miocene of Gansu Province, China. Journal of Vertebrate Paleontology 5: 336-344.

Zapfe, H. 1967. Ancylotherium in Obermiozän des Wiener Beckens. Annalen des Naturhistorischen Museums in Wien 71: 401-411.

Zapfe, H. 1974. Ein schizotheriiner Chalicotheriide aus pannonischen Schottern der Umgebung von Krems, Niederösterreich. Sitzungsberichte der Österreichischen Akademie der Wissenschaften, Mathematisch-naturwissenschaftliche Klasse (Abt. I) 182: 289-299.

Zapfe, H. 1979. Chalicotherium grande (Blainv.) aus der miozänen Spaltenfüllung von Neudorf an der March (Devinská Nová Ves), Tschechoslowakei. Neue Denkschriften des Naturhistorischen Museums in Wien 2: 1-282.

Ziegler, R. 1999. Order Insectivora. In The Miocene Land Mammals of Europe, eds. Rössner, G.E. and K. Heissig, 53-74, Munich: Pfeil. 